Comparative Effectiveness Review

Number 202

\title{
Effectiveness and Safety of Bronchial Thermoplasty in Management of Asthma
}
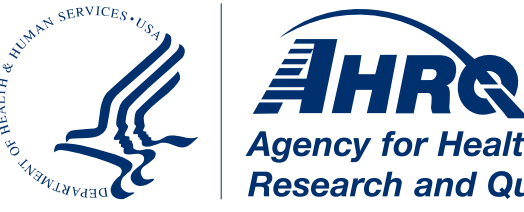

Agency for Healthcare Research and Quality
Effective Health

Care Program 


\title{
Comparative Effectiveness Review
}

Number 202

\section{Effectiveness and Safety of Bronchial Thermoplasty in Management of Asthma}

\author{
Prepared for: \\ Agency for Healthcare Research and Quality \\ U.S. Department of Health and Human Services \\ 5600 Fishers Lane \\ Rockville, MD 20857 \\ www.ahrq.gov
}

Contract No. 290-2015-00005-I

\author{
Prepared by: \\ ECRI Institute-Penn Medicine Evidence-based Practice Center \\ Plymouth Meeting, PA
}

\section{Investigators:}

Kristen E. D’Anci, Ph.D., and Marcus P. Lynch, Ph.D.*

Brian F. Leas, M.S., M.A.

Andrea J. Apter, M.D., M.Sc.

Tyra Bryant-Stephens, M.D.

Janice L. Kaczmarek, M.S.

Craig A. Umscheid, M.D., M.S.C.E.

Karen Schoelles, M.D., S.M.

*Dr. D’Anci and Dr. Lynch contributed equally to this report.

AHRQ Publication No. 18-EHC003-EF

December 2017 


\section{Key Messages}

\section{Purpose of Review}

To evaluate the effectiveness and safety of bronchial thermoplasty (BT), a procedure that uses heat to remove muscle tissue from the airways of adults with moderate to severe asthma. BT is usually given as three treatments 3 weeks apart.

\section{Key Messages}

- BT along with standard medical management, compared to medical management alone, may improve asthma control and quality of life, but evidence is insufficient to determine impact on asthma exacerbations.

- BT along with standard medical management, compared to a similar procedure without the heat (sham procedure), does not improve asthma control or hospitalizations but may reduce severe exacerbations and emergency room visits.

- BT causes more adverse events (such as worsening of asthma symptoms, respiratory infections, and coughing up blood) during the treatment period than standard treatment. Based on the available literature, there is still uncertainty about the balance of benefits and harms, and about which patients are most likely to benefit from the procedure. 
This report is based on research conducted by the ECRI Institute-Penn Medicine Evidence-based Practice Center (EPC) under contract to the Agency for Healthcare Research and Quality (AHRQ), Rockville, MD (Contract No. 290-2015-00005-I). The National Institutes of Health (NIH) National Heart, Lung, and Blood Institute (NHLBI) sponsored the report. The findings and conclusions in this document are those of the authors, who are responsible for its contents; the findings and conclusions do not necessarily represent the views of AHRQ or NIH/NHLBI. Therefore, no statement in this report should be construed as an official position of AHRQ, NIH/NHLBI, or the U.S. Department of Health and Human Services.

\section{None of the investigators have any affiliations or financial involvement that conflicts with the material presented in this report.}

The information in this report is intended to help health care decisionmakers-patients and clinicians, health system leaders, and policymakers, among others-make well-informed decisions and thereby improve the quality of health care services. This report is not intended to be a substitute for the application of clinical judgment. Anyone who makes decisions concerning the provision of clinical care should consider this report in the same way as any medical reference and in conjunction with all other pertinent information (i.e., in the context of available resources and circumstances presented by individual patients).

This report is made available to the public under the terms of a licensing agreement between the author and the Agency for Healthcare Research and Quality. This report may be used and reprinted without permission except those copyrighted materials that are clearly noted in the report. Further reproduction of those copyrighted materials is prohibited without the express permission of copyright holders.

AHRQ or U.S. Department of Health and Human Services endorsement of any derivative products that may be developed from this report, such as clinical practice guidelines, other qualityenhancement tools, or reimbursement or coverage policies, may not be stated or implied.

This report may periodically be assessed for the currency of conclusions. If an assessment is done, the resulting surveillance report describing the methodology and findings will be found on the Effective Health Care Program Web site at www.effectivehealthcare.ahrq.gov. Search on the title of the report.

Individuals using assistive technology may not be able to fully access information in this report. For assistance, contact epc@ahrq.hhs.gov.

Suggested citation: D’Anci KE, Lynch MP, Leas BF, Apter AJ, Bryant-Stephens T, Kaczmarek JL, Umscheid CA, Schoelles K. Effectiveness and Safety of Bronchial Thermoplasty in Management of Asthma. Comparative Effectiveness Review No. 202. (Prepared by the ECRI Institute-Penn Medicine Evidence-based Practice Center under Contract No. 290-2015-00005-I.) AHRQ Publication No. 18-EHC003-EF. Rockville, MD: Agency for Healthcare Research and Quality; December 2017. www.effectivehealthcare.ahrq.gov/reports/final.cfm. DOI: https://doi.org/10.23970/AHRQEPCCER202. 


\section{Preface}

The Agency for Healthcare Research and Quality (AHRQ), through its Evidence-based Practice Centers (EPCs), sponsors the development of evidence reports and technology assessments to assist public- and private-sector organizations in their efforts to improve the quality of health care in the United States. The National Heart, Lung, and Blood Institute, one of the National Institutes of Health, requested that AHRQ conduct a systematic review of the benefits and harms of bronchial thermoplasty for the management of asthma in adults and provided funding for this.

The reports and assessments provide organizations with comprehensive, evidence-based information on common medical conditions and new health care technologies and strategies. They also identify research gaps in the selected scientific area, identify methodologic and scientific weaknesses, suggest research needs, and move the field forward through an unbiased, evidencebased assessment of the available literature. The EPCs systematically review the relevant scientific literature on topics assigned to them by AHRQ and conduct additional analyses when appropriate prior to developing their reports and assessments.

To bring the broadest range of experts into the development of evidence reports and health technology assessments, AHRQ encourages the EPCs to form partnerships and enter into collaborations with other medical and research organizations. The EPCs work with these partner organizations to ensure that the evidence reports and technology assessments they produce will become building blocks for health care quality-improvement projects throughout the Nation. The reports undergo peer review and public comment prior to their release as a final report.

AHRQ expects that the EPC evidence reports and technology assessments, when appropriate, will inform individual health plans, providers, and purchasers as well as the health care system as a whole by providing important information to help improve health care quality.

If you have comments on this evidence report, they may be sent by mail to the Task Order Officers named below at: Agency for Healthcare Research and Quality, 5600 Fishers Lane, Rockville, MD 20857, or by email to epc@ahrq.hhs.gov.

Gopal Khanna, M.B.A.

Director

Agency for Healthcare Research and Quality

Stephanie Chang, M.D., M.P.H.

Director

Evidence-based Practice Center Program

Center for Evidence and Practice Improvement

Agency for Healthcare Research and Quality
Arlene S. Bierman, M.D., M.S.

Director

Center for Evidence and Practice Improvement Agency for Healthcare Research and Quality

Aysegul Gozu, M.D., M.P.H.

David W. Niebuhr, M.D., M.P.H., M.Sc.

Task Order Officers

Center for Evidence and Practice Improvement Agency for Healthcare Research and Quality 


\section{Acknowledgments}

The authors gratefully acknowledge Mary Butler, Ph.D., M.B.A., who served as Associate Editor, and the following individuals at ECRI Institute for their contributions to this project: Katherine Donahue, Gina Giradi, M.S., and Kristy McShea, M.S.L.I.S.

We also thank AHRQ Task Order Officers, Aysegul Gozu, M.D., M.P.H., and David W. Niebuhr, M.D., M.P.H. M.Sc., and the following individuals at National Heart, Lung, and Blood Institute (NHLBI): Janet M. DeJesus, M.S., Michelle Freemer, M.D., M.P.H., and Rachael L. Tracy, M.P.H. We appreciate the collaboration of our colleagues at other EPCs preparing reports for NHLBI, and particularly thank Diana Sobieraj and others at the University of Connecticut EPC, who provided the table and references for minimally important differences in Appendix D.

\section{Technical Expert Panel}

In designing the study questions and methodology at the outset of this report, the EPC consulted several technical and content experts. Broad expertise and perspectives were sought. Divergent and conflicted opinions are common and perceived as healthy scientific discourse that results in a thoughtful, relevant systematic review. Therefore, in the end, study questions, design, methodologic approaches, and/or conclusions do not necessarily represent the views of individual technical and content experts.

Technical Experts must disclose any financial conflicts of interest greater than $\$ 10,000$ and any other relevant business or professional conflicts of interest. Because of their unique clinical or content expertise, individuals with potential conflicts may be retained. The TOO and the EPC work to balance, manage, or mitigate any potential conflicts of interest identified.

The list of Technical Experts who provided input to this report follows:

Leonard B. Bacharier, M.D.*

Professor of Pediatrics

Washington University School of Medicine

St. Louis, MO

Thomas B. Casale, M.D.*

Professor of Internal Medicine and Pediatrics

University of South Florida

Tampa, FL

Michelle M. Cloutier, M.D.

Professor Emeritus of Pediatrics

UCONN Health Founding Director Asthma

Center, Connecticut Children's Medical

Center

Hartford, CT

Anne Fitzpatrick, Ph.D.*

Emory University, Department of Pediatrics

Children's Healthcare of Atlanta

Atlanta, GA
Theresa W. Guilbert, M.D., M.S.

Professor of Pulmonary Medicine and Pediatrics

Cincinnati Children's Hospital

Cincinnati, $\mathrm{OH}$

Monica Kraft, M.D.

Chair, Department of Medicine

University of Arizona College of Medicine

Tucson, AZ

Elizabeth C. Matsui, M.D., M.P.H.*

Professor of Pediatrics

Johns Hopkins University

Baltimore, MD

Wanda Phipatanakul, M.D., M.S.

Associate Professor of Pediatrics

Boston Children's Hospital

Boston, MA 
Michael E. Wechsler, M.D., M.M.Sc.*

Professor of Medicine

National Jewish Health

Denver, CO

*Provided input on Draft Report 


\section{Peer Reviewers}

Before publication of the final evidence report, EPCs sought input from independent Peer Reviewers without financial conflicts of interest. However, the conclusions and synthesis of the scientific literature presented in this report do not necessarily represent the views of individual reviewers.

Peer Reviewers must disclose any financial conflicts of interest greater than $\$ 10,000$ and any other relevant business or professional conflicts of interest. Because of their unique clinical or content expertise, individuals with potential nonfinancial conflicts may be retained. The TOO and the EPC work to balance, manage, or mitigate any potential nonfinancial conflicts of interest identified.

The list of Peer Reviewers follows:

Charles Barnes, Ph.D.

Professor of Pediatrics

University of Missouri-Kansas City

Kansas City, MO

Steve N. Georas, M.D.

Professor of Medicine

University of Rochester Medical Center

Rochester, NY
Mitchell H. Grayson, M.D.

Professor and Chief, Division of Allergy and Immunology

Department of Pediatrics

Nationwide Children's Hospital and

The Ohio State University School of Medicine

Columbus, $\mathrm{OH}$

David Miller, Ph.D.

Professor of Chemistry

Carleton University

Ottawa, ON, Canada 


\section{Effectiveness and Safety of Bronchial Thermoplasty in Management of Asthma}

\section{Structured Abstract}

Objective. This review assesses the effectiveness and safety of bronchial thermoplasty (BT) in adults with asthma.

Data sources. We systematically searched the gray literature and five bibliographic databases, MEDLINE $^{\circledR}$, Embase $^{\circledR}$, PubMed $^{\circledR}$, CINAHL $^{\circledR}$, and the Cochrane Library, through April 20, 2017.

Review methods. Eligible studies included systematic reviews, meta-analyses, randomized controlled trials (RCTs), and nonrandomized interventional studies with concurrent controls. Case reports and series were also considered for describing adverse events. Studies were evaluated for risk of bias using the Cochrane Risk of Bias instrument, and the evidence base was assessed using the methods guidance established by the Evidence-based Practice Center program.

Results. Fifteen studies, including three RCTs with 5-year single-arm followup in BT-treated patients ( $\mathrm{n}=432$ for the RCTs), examined the impact of BT in addition to standard care (continued medical management) on patients with asthma. BT and standard care improved asthma control (defined by the Asthma Control Questionnaire [ACQ] change from baseline to 12 months) and Asthma Quality of Life Questionnaire (AQLQ) scores more than standard care alone to a degree that was statistically significant but not clinically important (low strength of evidence [SOE]). However, BT and standard care, compared with a sham bronchoscopic procedure and standard care, did not improve asthma control (defined as ACQ change from baseline to 12 months), hospitalizations for respiratory symptoms, use of rescue medications, pulmonary physiology measures, or AQLQ scores (in the intention-to-treat analysis) (low SOE). In the same sham-controlled trial, BT reduced severe exacerbations after the 12-week treatment period to a statistically but not clinically important degree (low SOE), and patients undergoing BT had fewer emergency department visits than patients who had the sham bronchoscopic procedure (moderate SOE). In the RCTs comparing BT and standard care to standard care alone, evidence was insufficient to assess if BT reduced rates of severe exacerbations.

Common adverse events following BT during the 12-week treatment period in the RCTs included bronchial irritation, chest discomfort, cough, discolored sputum, dyspnea, night awakenings, and wheezing. Hospitalizations were more common in patients undergoing BT than with either standard care alone or sham bronchoscopy during the 12-week treatment period, as were upper respiratory tract infections, wheezing, dyspnea, lower respiratory tract infections, anxiety, and segmental atelectasis, but the events were too infrequent to achieve statistical significance. Severe adverse events (including post-procedure segmental atelectasis due to mucus plugging, hemoptysis, chest infections requiring hospitalization, and bronchial artery pseudoaneurysm) were also reported in six case reports and two small case series. Following the 12-week treatment period, rates of respiratory-related hospitalizations were not significantly different between groups for up to 5 years of followup. No deaths were attributed to BT.

Conclusions. While asthma control and quality of life measures modestly improved in patients undergoing BT compared to medical management alone in two controlled but nonblinded studies, these measures did not improve in the sham-controlled study. The sham-controlled, blinded study found modest improvements in severe exacerbations and significantly fewer 
emergency department visits following BT compared to the sham bronchoscopic procedure, but serious adverse events and post-procedure hospitalizations were more common during the 12week treatment period in patients undergoing BT than in patients undergoing sham treatment. The available body of literature on BT is small and uncertainty remains about appropriate patient selection criteria and the effects of the treatment beyond 5 years. 


\section{Contents}

Evidence Summary ............................................................................................................................. ES-1

Introduction ........................................................................................................................ 1

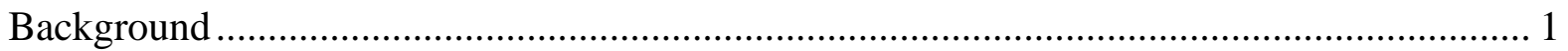

Role of Bronchial Thermoplasty in Management of Asthma .............................................. 1

Purpose of Systematic Review................................................................................... 1

Scope and Key Question ............................................................................................... 2

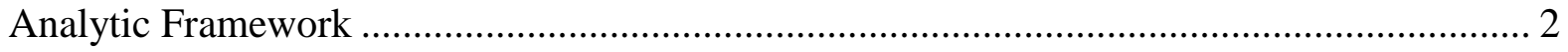

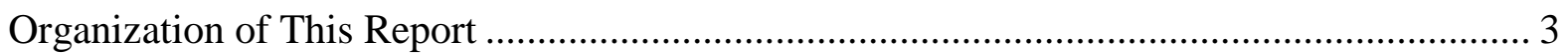

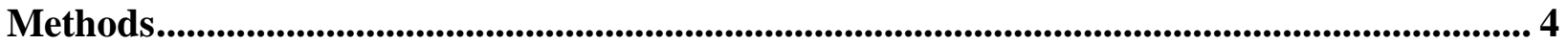

Topic Refinement and Review Protocol ............................................................................... 4

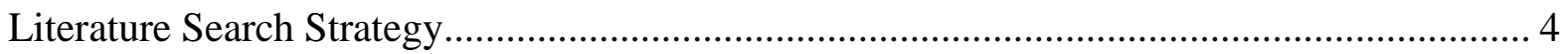

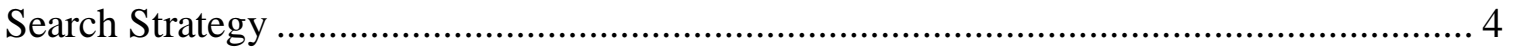

Inclusion and Exclusion Criteria.................................................................................... 5

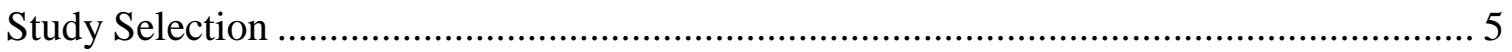

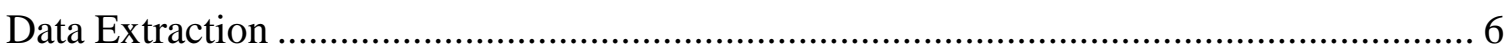

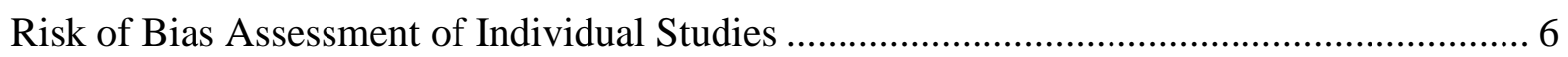

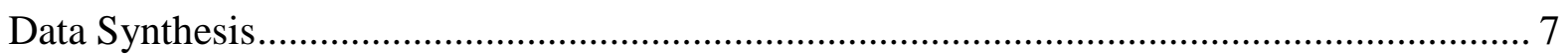

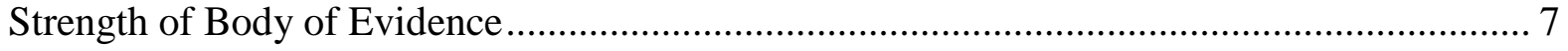

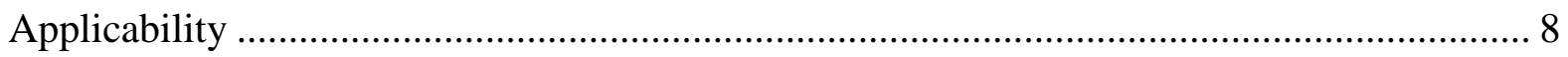

Peer Review and Public Commentary ……….................................................................. 8

Results ........................................................................................................................... 9

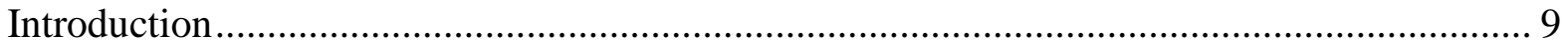

Results of Literature Searches .................................................................................... 9

Key Question 1. What are the benefits and harms of using bronchial thermoplasty in addition to standard treatment for the treatment of adult ( $\geq 18$ years) patients with asthma? 10

Description of Included Studies................................................................................... 10

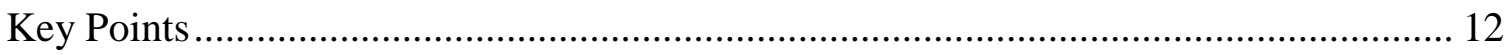

Detailed Synthesis................................................................................................ 13

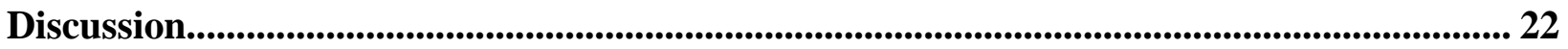

Key Findings and Strength of Evidence ........................................................................... 22

Findings Compared to What Is Already Known.................................................................... 22

Applicability ........................................................................................................................ 23

Implications for Clinical and Policy Decisionmaking ............................................................. 23

Limitations of the Systematic Review Process ..................................................................... 24

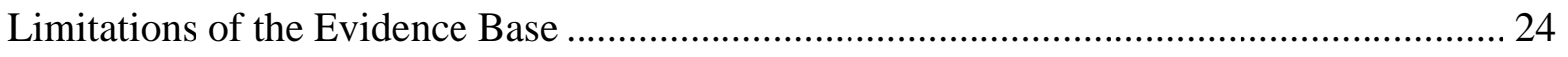

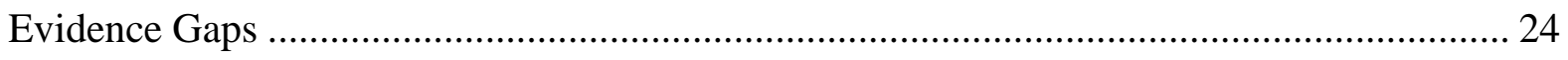

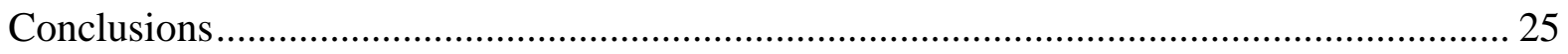

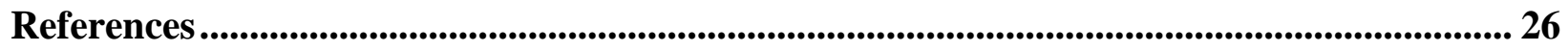

Abbreviations and Acronyms ........................................................................................................ 29 


\section{Tables}

Table 1. PICOTS (populations, interventions, comparisons, outcomes, timing, and setting) criteria for including studies in the review

Table 2. Patient inclusion criteria for the randomized controlled trials of bronchial

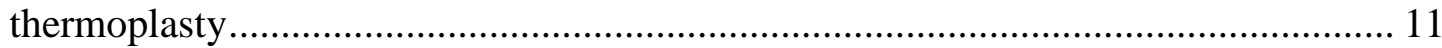

Table 3. Strength of evidence for bronchial thermoplasty interventions ............................... 16

\section{Figures}

Figure A. Analytic framework for bronchial thermoplasty in asthma.............................. ES-2

Figure 1. Analytic framework for bronchial thermoplasty in asthma..................................... 3

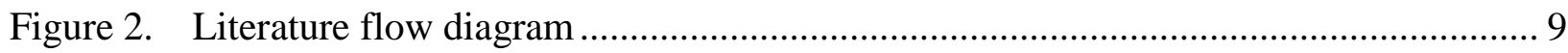

\section{Appendixes}

Appendix A. Search Strategies

Appendix B. Excluded Studies

Appendix C. Evidence Tables

Appendix D. Minimally Important Differences for Asthma Study Outcomes

Appendix E. Ongoing Clinical Trials

Appendix F. Reference List for Appendixes B, C, and D 


\section{Evidence Summary}

\section{Objectives and Rationale for Review}

This report summarizes a systematic review, "Effectiveness and Safety of Bronchial Thermoplasty in Management of Asthma,” and identifies needs for future research. This was one of the six high-priority topics within asthma identified by an National Heart, Lung, and Blood Institute Advisory Council Asthma Expert Working Group. ${ }^{1}$

The objective of the systematic review is to assess the effectiveness and safety of bronchial thermoplasty (BT) in adults with asthma.

\section{Background}

Patients with severe, persistent asthma are managed with multiple medications that may include inhaled, orally administered, and biologic therapeutics. Some of these patients might be eligible for BT, an interventional treatment option that involves the delivery of controlled radiofrequency thermal energy to the walls of accessible proximal airways with the intent of reducing excess airway smooth muscle tissue in the airways and reducing the frequency of severe asthma exacerbations on a long-term basis. In April 2010, the U.S. Food and Drug Administration approved the Alair BT system for use in patients 18 years of age or older with severe, persistent asthma.

This report's main objective is to conduct a systematic review of the benefits and harms of BT for the management of asthma in adults. In this review, we address the following Key Question (KQ):

What are the benefits and harms of using BT in addition to standard treatment for the treatment of adult ( $\geq 18$ years) patients with asthma?

Figure A shows the analytic framework for the review. 
Figure A. Analytic framework for bronchial thermoplasty in asthma

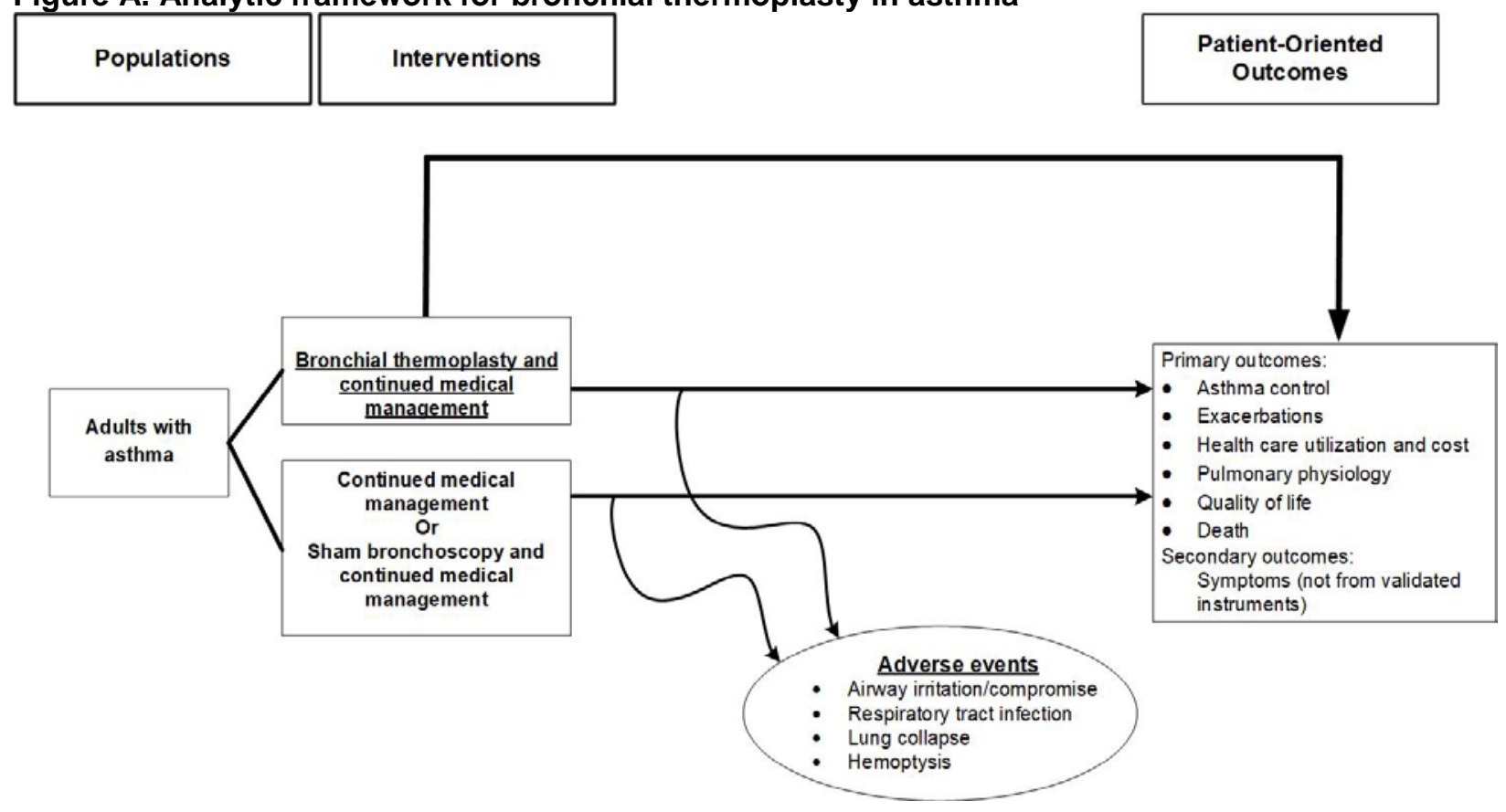

\section{Data Sources}

MEDLINE $^{\circledR}$, Embase $^{\circledR}$, PubMed ${ }^{\circledR}$, CINAHL $^{\circledR}$, the Cochrane Library, and the gray literature were searched through April 20, 2017. The systematic review protocol is available in the full report.

\section{Results}

Fifteen studies, including three randomized controlled trials (RCTs) with 5-year single-arm followup in BT-treated patients ( $\mathrm{n}=432$ for the RCTs), examined the impact of BT on patients with severe asthma. The key findings of the review are listed below along with the strength of evidence (SOE).

- Patients treated with BT and standard care (medical management) showed statistically greater improvements in asthma control (as measured by the Asthma Control Questionnaire [ACQ]) and quality of life (as measured by the Asthma Quality of Life Questionnaire [AQLQ]) compared with patients undergoing standard care (medical management) only (SOE: low). However, the clinical importance of the changes is unclear.

- Evidence as to whether patients treated with BT and standard care versus standard care alone experienced different rates of severe exacerbations following treatment was inconclusive (SOE: insufficient). While rates of mild exacerbations improved to a greater extent in the BT and standard care group than in the standard care only group, the clinical importance of the difference is unclear. (SOE: low).

- Patients treated with BT and standard care used statistically significantly less rescue medication than patients receiving standard care alone, but the clinical importance of the difference is unclear. (SOE: low). 
- Patients given BT and standard care compared with patients given the sham bronchoscopic procedure and standard care had no difference in asthma control scores, as measured by ACQ; in hospitalizations for respiratory symptoms; in use of rescue medication; in number of days rescue medications were required; or in pulmonary physiology measures (forced expiratory volume in 1 second [FEV1] and morning peak expiratory flow [PEF]) (SOE for all outcomes: low).

- Patients treated with BT and standard care experienced statistically significantly fewer exacerbations (those requiring systemic corticosteroids or doubling of inhaled corticosteroid dose) compared with those receiving the sham bronchoscopic procedure and standard care after the treatment period was complete (3 procedures over 6 weeks, followed by an additional 6 weeks) through the 12-month followup (post-treatment period), but the clinical importance of this difference was unclear (SOE: low).

- Patients treated with BT and standard care had fewer emergency department (ED) visits compared with those receiving the sham bronchoscopic procedure and standard care during the post-treatment period (SOE: moderate).

- Evidence as to whether patients receiving BT and standard care versus the sham bronchoscopic procedure and standard care had different quality of life (AQLQ) scores was inconclusive (SOE: insufficient). Analysis of results for the intention-to-treat population did not find improvement, but analysis of results for the per-protocol population found a difference that may not be clinically important, as it did not achieve the minimum important difference for this measure. A responder analysis (proportion of patients who achieved the minimum important difference) favored the BT and standard care group, but this outcome was not prespecified.

- Patients treated with BT developed the following common adverse events: bronchial irritation, chest discomfort, cough, discolored sputum, dyspnea, night awakenings, and wheezing. Serious adverse events occurred more frequently in BT-treated patients than in patients receiving sham treatment and/or standard care during the 12-week treatment period. No deaths were attributed to BT.

\section{Discussion}

We identified three primary RCTs $(n=432)$ of BT, as well as their associated followup studies $(n=245)$. Nine observational studies $(n=55)$ also reported outcomes associated with BT. Relatively few randomized studies have examined BT in patients with severe asthma and addressed the question in this review, with only two multicenter RCTs comparing BT with standard care (medical management), and one multicenter RCT comparing BT to a sham bronchoscopy intervention with standard care continued in both groups. Compared with standard care, the evidence from two RCTs suggests that BT improved asthma control (defined by the ACQ change from baseline to 12 months), health care utilization (defined by rescue medication use), and quality of life (low strength of evidence [SOE]). However, the minimally important difference (MID) was not met for these measures, and the clinical relevance of these findings is uncertain. Similarly, rates of mild exacerbations were reduced following BT (low SOE), but concerns about the magnitude of the effect and directness of the findings led us to conclude that the clinical relevance of this finding was uncertain. The evidence base was insufficient to draw conclusions about BT's effects on severe exacerbations, FEV1, and airway hyper-responsiveness compared with standard care. 
Compared with sham treatment, the intention-to-treat analysis in a single RCT suggests that BT had no effect on asthma control (defined as improvement in ACQ from baseline), hospitalizations for respiratory symptoms, health care utilization (rescue medication usage), pulmonary physiology measures (FEV1 \% predicted and morning PEF [L/min]), or other asthma symptoms outcomes (low SOE). However, reduced risk of severe exacerbations was suggested (low SOE), although the clinical importance of this difference was unclear. BT was associated with fewer ED visits than sham treatment during the post-treatment period (moderate SOE). The evidence was inconclusive regarding quality of life scores following BT or sham (insufficient $\mathrm{SOE}$ ). Serious adverse events attributed to BT were infrequent, and no deaths were reported.

Clinicians whose patients are potential candidates for BT may want to consider the evidence presented in this review, including the highly selected and heterogeneous study populations, limited improvement in outcomes, and rates of adverse events (including asthma worsening and respiratory tract infections during the treatment period) when determining BT's appropriateness for their patients.

\section{Conclusions}

Three RCTs and several descriptive studies meeting our inclusion criteria have evaluated BT. Based on the available literature, BT may be modestly beneficial in some patients with asthma, but is not without risks in any population. The risk of adverse events is higher early in treatment, while benefit is typically observed weeks to months after therapy and can last for at least 5 years, after which the effect is unknown

\section{Reference}

1. National Heart, Lung, and Blood Advisory Council Asthma Expert Working Group. Needs Assessment Report for Potential Update of the Expert Panel Report-3 (2007): Guidelines for the Diagnosis and Management of Asthma. 2015. 


\section{Introduction}

\section{Background}

Asthma is a chronic inflammatory disorder of the airways, characterized by varying degrees of airflow obstruction. Bronchoconstriction, inflammatory cell infiltration, and airway edema reduce airflow intermittently, often in response to specific exposures, resulting in respiratory symptoms. ${ }^{1}$ In the United States, asthma's prevalence has increased over the past decade, from an estimated 22.2 million Americans in 2005 to 24 million Americans in 2014. ${ }^{2,3}$ Asthma can significantly affect patients' and families' quality of life and ability to pursue activities such as school, work, and exercise. Globally, asthma ranks $14^{\text {th }}$ in prevalence based on the burden of disease, as measured by disability-adjusted life years. ${ }^{4}$ In the United States, asthma contributes significantly to health care resource utilization and associated costs. For example, in 2012, asthma was one of the top 20 leading diagnosis groups for primary care visits and was the main reason for 1.8 million emergency department visits and 439,000 hospitalizations. While the severity of disease varies between patients and over time in the same patient, asthma can be fatal, accounting for approximately 1 death per 100,000 Americans. ${ }^{5}$

\section{Role of Bronchial Thermoplasty in Management of Asthma}

Patients with severe, persistent asthma are managed with multiple medications that may include inhaled, orally administered, and biologic therapeutics. Some of these patients might be eligible for bronchial thermoplasty (BT), an interventional treatment option that involves the delivery of controlled radiofrequency (RF) thermal energy to the walls of accessible proximal airways with the intent of reducing excess smooth muscle tissue in the airways. The Alair ${ }^{\mathrm{TM}}$ Bronchial Thermoplasty System (Boston Scientific Corp.) consists of a radiofrequency controller, footswitch, and a patient return electrode, which provides temperature-controlled delivery of RF energy to a disposable, single-use catheter for a predetermined duration. The Alair Catheter was designed for use with high-frequency compatible flexible bronchoscopes, delivering energy to the desired airway site while relaying temperature feedback to the controller. Physicians perform three bronchoscopic procedures to different areas of the lung approximately 3 weeks apart: the lower lobe of the right lung, the lower lobe of the left lung, then both upper lobes in the final procedure. In each procedure, the physician performs about 45 to 60 smooth muscle ablations heating the airway wall to about $150^{\circ} \mathrm{F}$ for 10 seconds. Each procedure usually takes under an hour. Sedation for BT typically involves a combination of moderate or deep sedation and local anesthesia. ${ }^{6}$ In April 2010, the U.S. Food and Drug Administration approved the Alair BT system for use in patients 18 years of age or older with severe, persistent asthma.

\section{Purpose of Systematic Review}

In 1989, the National Heart, Lung, and Blood Institute (NHLBI) initiated the National Asthma Education and Prevention Program (NAEPP) to address the growing concern about asthma in the United States. One of NAEPP's first accomplishments was to convene a panel of experts, who produced a report in 1991, The National Asthma Education and Prevention Program Expert Panel Report (EPR): Guidelines for the Diagnosis and Management of Asthma. The guidelines address the diagnosis, evaluation, and treatment of asthma. Given that the most recent report, EPR-3, was published in $2007,{ }^{1}$ NHLBI assessed the need for an update by 
requesting information from the public, NAEPP Coordinating Committee Members, its affiliates, and members of the 2007 Expert Panel. Collected information was provided to the NHLBI Advisory Council Asthma Expert Working Group, which produced a report to summarize the process and recommendations from their needs assessment. ${ }^{7}$ The Working Group identified six high-priority topics that should be updated. For each topic, Key Questions meriting a systematic literature review were formulated. NHLBI engaged the Agency for Healthcare Research and Quality to perform the systematic reviews through its Evidence-Based Practice Centers. This document represents the systematic review "Role of Bronchial Thermoplasty in Management of Asthma.”

\section{Scope and Key Question}

This report's main objective is to conduct a systematic review of the benefits and harms of BT for the management of asthma in adults. In this review, we address the following Key Question (KQ):

Key Question 1: What are the benefits and harms of using BT in addition to standard treatment for the treatment of adult ( $\geq 18$ years) patients with asthma?

\section{Analytic Framework}

We developed an analytic framework to guide the systematic review process (Figure 1). 
Figure 1. Analytic framework for bronchial thermoplasty in asthma

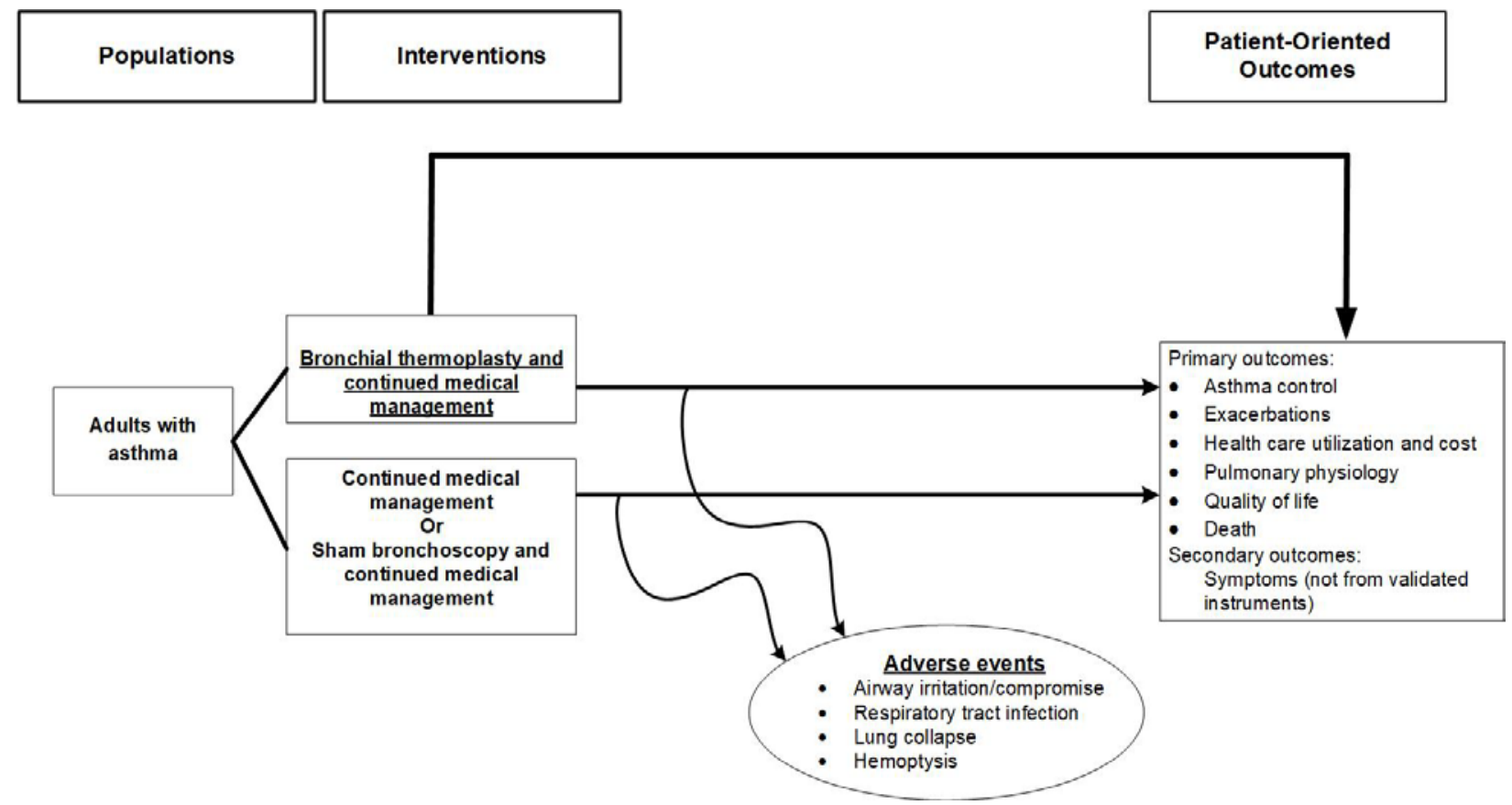

\section{Organization of This Report}

In the remaining three chapters of this report, we describe the methods for this systematic review, present the results for the KQ, and discuss the overall findings. In the Results chapter, we provide the results of the literature searches and screening procedures, as well as descriptions of included studies, key points, detailed syntheses of the studies, and strength-of-evidence tables for the KQ. The Discussion chapter reviews the key findings and strength of evidence for the KQ, places the findings in the context of previous systematic reviews and clinical practice guidelines, examines the general applicability of the studies, discusses implications for decisionmaking, describes limitations of the systematic review process and the evidence base for the KQ, and identifies knowledge gaps that require further research.

A list of acronyms and abbreviations appears after the references, followed by six appendixes: Appendix A. Search Strategies; Appendix B. Excluded Studies; Appendix C. Evidence Tables; Appendix D. Minimally Important Differences for Asthma Study Outcomes; Appendix E. Ongoing Clinical Trials; and Appendix F. Reference List for Appendixes B, C, and C. 


\section{Methods}

\section{Topic Refinement and Review Protocol}

The National Heart, Lung, and Blood Institute (NHLBI) initially nominated this topic, as described in the Introduction. We generated an analytic framework, preliminary Key Questions (KQs), and preliminary inclusion/exclusion criteria in the form of PICOTS (populations, interventions, comparators, outcomes, timing, and settings). A Technical Expert Panel (TEP) was convened for this report. The TEP consisted of nine scientists and clinicians, including individuals with expertise in the clinical management of pediatric and adult asthma, the use of bronchial thermoplasty (BT), and implementation of environmental-control interventions to reduce exposure to allergens in the home. TEP members participated in conference calls and discussions through email to review the scope, analytic framework, KQs, and PICOTS, and provided input on the information and categories included in evidence tables and the analysis. A list of the TEP members is included in the front matter of this report. The final protocol of the review was posted on the Effective Health Care Web site on October 11, 2016. A full version of our protocol for this systematic review is available online (https://effectivehealthcare.ahrq.gov/ehc/products/643/2318/asthma-nonpharmacologictreatment-protocol-161004.pdf), ${ }^{8}$ and is registered in PROSPERO (http://www.crd.york.ac.uk/PROSPERO) registration number CRD42017055547). ${ }^{9}$

Based on peer review and public feedback on the draft report, we separated the two KQs described in the protocol into two separate reports. The guidance provided by the TEP and the content included in the posted protocol reflect the larger scope of work as initially planned.

\section{Literature Search Strategy}

\section{Search Strategy}

Literature searches were performed by Medical Librarians at the ECRI Institute Evidencebased Practice Center (EPC) Information Center and followed established systematic review protocols. Searches covered the literature published from database inception (dates vary, see Appendix A) through April 20, 2017.

We searched the following databases using controlled vocabulary and text words: Embase ${ }^{\circledR}$ and MEDLINE ${ }^{\circledR}$ (searched together on the EMBASE.com platform), PubMed ${ }^{\circledR}$ (In Process citations), CINAHL ${ }^{\circledR}$ (Cumulative Index to Nursing and Allied Health Literature), and the Cochrane Library.

We used text words to search gray literature sources and the Web sites of relevant organizations, such as the U.S. Food and Drug Administration Web site, identified by the clinical experts on the project team. A complete list of the resources we searched, as well as search concepts and strategies, are available in Appendix A.

Reference lists from systematic reviews and meta-analyses were reviewed and compared against our retrieved articles. If a systematic review contained references that appeared to meet our inclusion criteria, but had not been captured by our initial search results, the search strategy was refined to include these articles. Supplemental Evidence and Data for Systematic Reviews submitted by interested parties were also reviewed.

Literature screening was performed in duplicate using the database Distiller SR (Evidence Partners, Ottawa, Ontario, Canada). Literature search results were initially screened for 
relevancy. Relevant abstracts were screened against the inclusion and exclusion criteria in duplicate. Studies that appeared to meet the inclusion criteria were retrieved and screened again in duplicate against the inclusion and exclusion criteria. All disagreements were resolved by consensus discussion between the two original screeners.

\section{Inclusion and Exclusion Criteria}

\section{Publication Criteria}

Included articles must have been published as full-length, peer-reviewed studies. Abstracts and meeting presentations were not included because they do not include sufficient details about experimental methods to permit an evaluation of study design and conduct; they may also contain only a subset of measured outcomes. ${ }^{10,11}$ Additionally, it is not uncommon for abstracts that are published as part of conference proceedings to have inconsistencies compared with the final study publication or to describe studies that are never published as full articles. ${ }^{12-16}$

When a study with an English-language abstract but published in a foreign language was identified, the abstract was assessed against the full set of inclusion/exclusion criteria. If the study appeared to fit the inclusion criteria, we evaluated whether excluding the study might result in language bias (e.g., if the findings differ from other included studies.) If language bias seemed unlikely, the study was excluded.

\section{Study Selection}

We followed the PICOTS (Table 1) framework to develop the inclusion criteria for studies. We included studies of adults with a diagnosis of asthma who underwent BT. Studies had to report on the outcomes prespecified in our PICOTS. Study inclusion was not restricted by language of publication or treatment duration. Randomized controlled trials (RCTs) and nonrandomized interventional studies with concurrent controls (e.g., nonrandomized trials) were considered for inclusion for assessment of benefits. Single-arm extensions of RCTs were included to describe long-term changes in efficacy or safety in patients treated with BT. Case reports or case series that describe adverse events were also considered for inclusion for reporting adverse events. In vivo, in vitro, and animal studies were excluded. 
Table 1. PICOTS (populations, interventions, comparisons, outcomes, timing, and setting) criteria for including studies in the review

\begin{tabular}{|c|c|}
\hline PICOTS & Criteria \\
\hline Populations & $\begin{array}{ll}\text { - } & \text { Asthma } \\
\text { - } & \geq 18 \text { years old }\end{array}$ \\
\hline Interventions & - $\quad$ Bronchial thermoplasty \\
\hline Comparators & $\begin{array}{l}\text { Treatments used in patients with asthma excluding thermoplasty } \\
\text { - } \quad \text { Standard care: medical management as determined by treating physician } \\
\text { - } \quad \text { Sham: bronchoscopy without thermoplasty }\end{array}$ \\
\hline Outcomes & 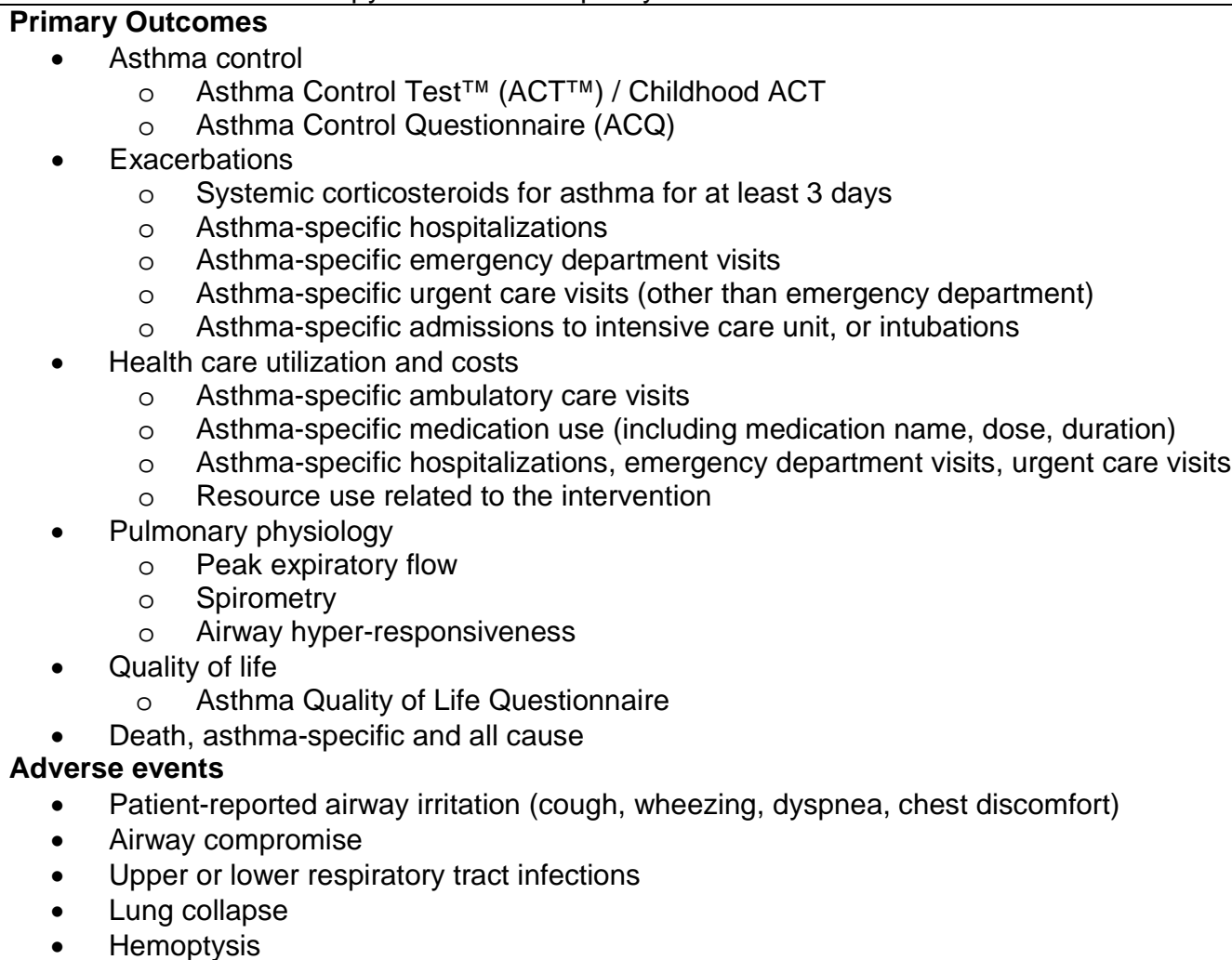 \\
\hline Timing & - $\quad$ Studies with all lengths of followup duration will be considered \\
\hline Setting & - $\quad$ Clinical settings \\
\hline
\end{tabular}

\section{Data Extraction}

Data were extracted using Microsoft Word. All extracted data were double-checked by a second investigator. All discrepancies were resolved by consensus discussion among the two investigators and an additional person as needed. Elements abstracted included general study characteristics, patient characteristics, details of interventions, outcomes data, and risk of bias items.

\section{Risk of Bias Assessment of Individual Studies}

We used the Cochrane Collaboration's tool for assessing risk of bias in RCTs. ${ }^{17}$ Study characteristics were rated as introducing "low," "high,” or “unclear” risk of bias. Two independent reviewers assessed risk of bias, and discrepancies were addressed through consensus discussion.

We considered the funding source of individual studies as presenting a potentially important risk of bias. Therefore, we noted in the risk of bias table any study that reported receiving all or 
part of its funding from a commercial manufacturer of an intervention or was coauthored by one or more of its employees. We rated the "Other Sources of Bias" component in the Cochrane scale as "high" in cases in which study funding presented a potential conflict of interest.

We created a summary assessment of “Overall Risk of Bias” by grouping the criteria included in the Cochrane tool into four categories based on the nature of their respective threats to validity. The four categories address: (1) participant enrollment (comprising "sequence generation" and "allocation concealment"), (2) blinding ("blinding of participants, personnel and outcome assessors"), (3) outcome data ("incomplete outcome data" and "selective outcome reporting”), and (4) other sources of bias. We then concluded that an individual study was at "high" overall risk of bias if it was assigned a "high" risk rating for one or more discrete criteria in at least two different categories. A study was determined to be at "medium" overall risk of bias if it was assigned a "high" risk rating in only one discrete criterion, or in two criteria within the same category. For example, if a study was at "high" risk of bias for both "sequence generation" and "incomplete outcome data," the overall risk would be "high" because there is concern about two different categories. Conversely, if a study was at "high" risk of bias for "sequence generation" and "allocation concealment," then the overall risk would be "medium" because the two criteria are in the same category. If no criteria were assessed to be at "high" risk, then the overall risk of bias was "low." However, if we rated the risk as "Unclear" in two or more categories, then the overall risk was "unclear."

\section{Data Synthesis}

We synthesized the data qualitatively. Due to the clinical heterogeneity and the small number of included studies, we did not attempt to combine data from the studies quantitatively using meta-analyses.

We have described outcomes as statistically significant when identified as such by the authors of the primary studies or by the EPC's calculations from reported data. Statistical significance, however, does not always equate with clinically significant changes in outcomes. In the strength of evidence (SOE) tables, we note any cases in which a statistically significant result was not associated with a minimum important difference (see Appendix D). We calculated effect sizes and 95\% confidence intervals for within study comparisons when the publications provided sufficient data.

Critical outcomes for the KQ included the following validated outcomes: asthma-control measures (Asthma Control Questionnaire), asthma-exacerbation measures, asthma-related health care utilization and costs (use of rescue medication), asthma-related pulmonary physiology (forced expiratory volume in 1 second [or as \% predicted] and morning peak expiratory flow), and the Asthma Quality of Life Questionnaire. We also considered symptoms reported in other ways and adverse events as critical outcomes.

\section{Strength of Body of Evidence}

We graded the SOE based on the methods guidance established by the EPC program. This approach incorporates five key domains: study limitations, consistency, directness, precision, and reporting bias.

We determined study limitations by appraising the degree to which the included studies had adequate protection against bias (i.e., good internal validity). We downgraded for study limitations when 50 percent or more of the studies evaluated for a given outcome were at "high" overall risk of bias as described above. If the evidence permits a conclusion, then, all else being 
equal, a set of studies at low risk of bias yields a higher SOE rating than a set of studies at high risk of bias.

We assessed consistency of results for the same outcome among the available studies in terms of the direction and magnitude of effect. We downgraded for inconsistency when there was heterogeneity in the effects of an intervention across studies for a given outcome that could not be explained through identifiable differences in study characteristics. We downgraded for unknown consistency when only a single study was included for an outcome.

The evidence was considered indirect if the populations, interventions, comparisons, or outcomes used within studies did not directly correspond to the comparisons we were evaluating, and we suspected there may be differences in effect based on that indirectness.

Precision is the degree of certainty surrounding an effect estimate with respect to a given outcome and is affected by sample size and number of events and most commonly represented by the width of confidence intervals. We also considered the evidence to be imprecise when key components of the outcome data that studies provided were not fully reported (e.g., measures of variance were not included) or when it was not possible to derive an estimate of effect based on the available data.

Reporting bias includes publication bias, outcome-reporting bias, and analysis-reporting bias. Given the small number of studies we evaluated, we did not examine funnel plots. We downgraded for reporting bias when we detected a likelihood of outcome-reporting bias (important clinical outcomes appear to have been collected but not reported by the studies within a comparison) or analysis reporting bias (important comparisons were not analyzed).

\section{Applicability}

Several a priori factors of this evidence base may limit the applicability of findings. We evaluated the available literature in context with our specific PICOTS criteria and have described differences between them in the Discussion chapter. The major issues related to applicability of this evidence base include patient selection criteria and characteristics as well as the choice of comparators and outcomes reported in the studies.

\section{Peer Review and Public Commentary}

Experts in clinical management of asthma, and strategies to minimize the presence and effect of indoor inhalant allergens, were invited to provide external peer review of the draft report. Agency for Healthcare Research and Quality (AHRQ) staff, an Associate Editor, and representatives from NHLBI reviewed the draft report before it was distributed for peer review. The draft report was also posted on the AHRQ Web site from April 26, 2017, to May 25, 2017, to enable public comment. We revised the report based on peer and public feedback, and noted these revisions in the Disposition of Comments Report. The disposition report is made available 3 months after the final review is posted on the AHRQ Web site.

Several important revisions were made to the report in response to peer review and public comment. As noted above, this review was initially designed to include the current Key Question as well as an additional Key Question addressing the effectiveness of indoor allergen reduction. We separated the larger review into two independent reports in response to substantial feedback. We clarified some of the study characteristics, outcomes, and terminology used throughout the review, and reorganized the results to increase clarity. Finally, we expanded the Discussion to address the important need for further sham-controlled studies. 


\section{Results}

\section{Introduction}

We begin by describing the results of our literature searches. We then provide a brief description of the included studies. We provide a detailed description of the studies, key summary points, a detailed analysis of the results, and a table that presents the strength of evidence (SOE).

\section{Results of Literature Searches}

The literature searches identified three randomized controlled trials (RCTs) and 12 additional studies (see Figure 2). Articles that were excluded at the full-text level with reasons for their exclusion are listed in Appendix B.

Figure 2. Literature flow diagram

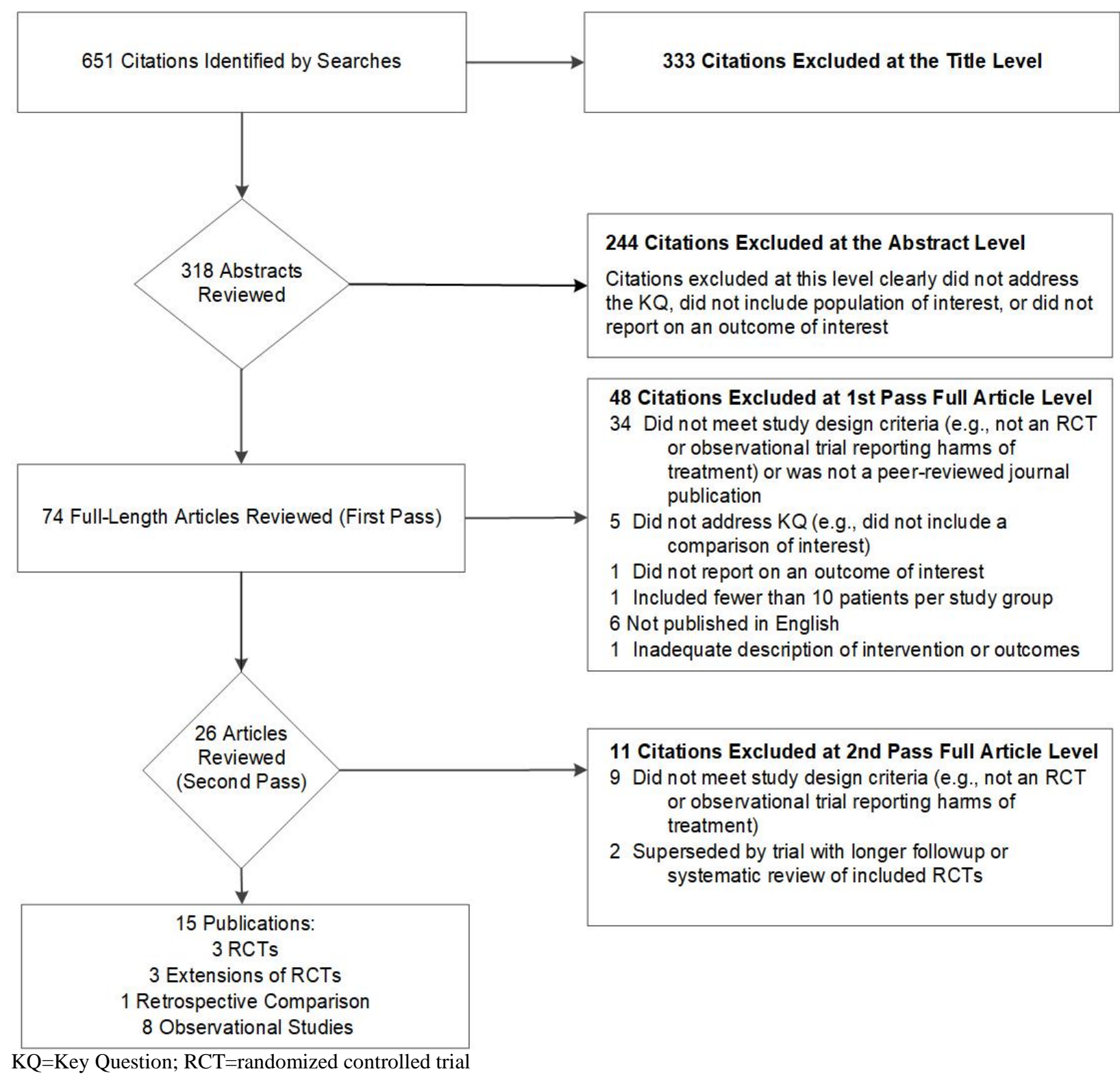




\section{Key Question 1. What are the benefits and harms of using bronchial thermoplasty in addition to standard treatment for the treatment of adult ( $\geq 18$ years) patients with asthma? \\ Description of Included Studies}

Fifteen studies were included to address the benefits and harms of bronchial thermoplasty (BT). Six trials, including three RCTs $(n=432)^{18-20}$ and their 5-year, single-arm extension studies, ${ }^{21-23}$ provided outcomes related to safety and efficacy. One of the extension studies also reported data for the control arm through 3 years. Two of the RCTs (Research In Severe Asthma [RISA $^{20}[\mathrm{n}=32]$ and Asthma Intervention Research [AIR] $\left.{ }^{19}[\mathrm{n}=112]\right)$ compared BT plus standard care (i.e., medical management as determined by treating physician) to standard care alone for up to 12 months. The third $\mathrm{RCT}^{18}$ (AIR 2, n=288) compared BT (with standard care) with bronchoscopic sham procedures (i.e., bronchoscopy without thermoplasty, along with standard care) as a control for up to 12 months. The manufacturer of the Alair BT system, Boston Scientific, funded all three RCTs. To better assess the generalizability of these studies, we included an additional study comparing outcomes of patients receiving BT as part of an RCT with those of "real-world" patients not enrolled in an RCT who were receiving BT at the same clinic. ${ }^{24}$ For additional consideration of the potential harms of BT, eight descriptive studies were included, consisting of six case studies ${ }^{25-30}$ and two case series. ${ }^{31,32}$

The U.S. Food and Drug Administration (FDA)-approved indication for the Alair system is for severe, persistent asthma in adults whose asthma is not controlled by inhaled corticosteroids (ICS) and long-acting beta agonists (LABA). However, the RCTs included patients with a range of asthma severity. We provide the detailed study inclusion criteria in Table 2. 
Table 2. Patient inclusion criteria for the randomized controlled trials of bronchial thermoplasty

\begin{tabular}{|c|c|}
\hline Study & Study Inclusion Criteria \\
\hline $\begin{array}{l}\left.\text { RISA Study (Pavord } 2007^{20}\right) \\
\text { BT and standard care vs. standard care } \\
N=34\end{array}$ & $\begin{array}{l}\text { Asthma severity: severe, requiring daily ICS at }>750 \mathrm{mcg} \text { fluticasone } \\
\text { equivalent and LABA } 100 \text { mcg salmeterol equivalent; } \leq 30 \mathrm{mg} / \mathrm{d} \\
\text { prednisone equivalent; } \\
\text { Spirometry: prebronchodilator FEV } \mathrm{F}_{1} \geq 50 \% \text { predicted; airway } \\
\text { hyperresponsiveness (methacholine challenge or response to } \\
\text { bronchodilator) } \\
\text { Additional: Uncontrolled symptoms while on maintenance therapy - } \\
\text { rescue medication used on } 8 \text { of } 14 \text { days prior to enrollment or daytime } \\
\text { symptoms on } 10 \text { of } 14 \text { days; nonsmoker } \geq 1 \text { year }\end{array}$ \\
\hline $\begin{array}{l}\text { AIR Study }\left(\operatorname{Cox} 2007^{19}\right) \\
\text { BT and standard care vs. standard care } \\
N=112\end{array}$ & $\begin{array}{l}\text { Asthma severity: moderate or severe, requiring daily ICS at }>200 \text { mcg } \\
\text { BPD equivalent and LABA } 100 \text { mcg salmeterol equivalent; stable } \\
\text { disease in } 6 \text { weeks prior to entry } \\
\text { Spirometry: prebronchodilator } F E V_{1} 60 \text { to } 85 \% \text { predicted; } \\
\text { Methacholine } \mathrm{PC}_{20}<8 \mathrm{mg} / \mathrm{mL} \\
\text { Additional: Worsening of } A C Q \geq 0.5 \text { when off LABA for } 2 \text { weeks; }<3 \\
\text { lower respiratory tract infections requiring antibiotics in previous } 12 \\
\text { months, none in prior } 6 \text { weeks; nonsmoker } \geq 1 \text { year; }<4 \text { puffs/day short- } \\
\text { acting beta- } 2 \text { agonist }\end{array}$ \\
\hline $\begin{array}{l}\text { AIR } 2 \text { (Castro } 2010^{18} \text { ) } \\
\text { BT and standard care vs. sham } \\
\text { (bronchoscopy without thermoplasty) and } \\
\text { standard care } \\
N=297\end{array}$ & $\begin{array}{l}\text { Asthma severity: severe asthma requiring daily ICS at }>1,000 \mathrm{mcg} \\
\text { BPD equivalent and LABA } 100 \text { mcg salmeterol equivalent; }<10 \mathrm{mg} \\
\text { OCS/day; } \geq 2 \text { symptomatic days in prior } 4 \text { weeks } \\
\text { Spirometry: prebronchodilator } \mathrm{FEV}_{1} \geq 60 \% \text { predicted; Methacholine } \\
\mathrm{PC}_{20}<8 \mathrm{mg} / \mathrm{mL} \\
\text { Additional: AQLQ } \leq 6.25 ;<3 \text { hospitalizations for asthma; }<3 \text { lower } \\
\text { respiratory tract infections and <4 pulses of OCS in prior year; } \\
\text { Additional exclusions: "life threatening" asthma; use of } \\
\text { immunosuppressants, beta-adrenergic blocking agents or } \\
\text { anticoagulants; chronic sinus disease or emphysema; smoking in past } \\
\text { year or } \geq 10 \text { pack-year smoking history }\end{array}$ \\
\hline
\end{tabular}

ACQ: Asthma Control Questionnaire (Range 0-6); AIR: Asthma Intervention Research; AQLQ: Asthma Quality of Life Questionnaire (Range 1-7); BT: bronchial thermoplasty; ED: emergency department; FEV 1 : forced expiratory volume in 1 second; ICS: inhaled corticosteroid; LABA: long-acting beta-2 agonist; mcg: microgram; mg/mL: milligrams per milliliter; OCS: oral corticosteroids; $\mathrm{PC}_{20}=$ provocative concentration of methacholine causing a $20 \%$ drop in FEV 1 ; RISA: Research In Severe Asthma

The standard care provided during the course of the studies was a continuation of maintenance treatments (e.g., ICS with or without oral corticosteroids, LABA) at entry. Patients in the AIR study received prednisone $50 \mathrm{mg}$ the day of and day after each BT procedure, then maintenance therapy until month 3, at which point the LABA was withdrawn for at least 2 weeks. If symptoms emerged, the LABA was resumed, and additional attempts were made to withdraw it at 6 months and 12 months. ${ }^{19}$ In the RISA study, patients in both groups were given $50 \mathrm{mg}$ of prednisone per day for 5 days starting 3 days before each BT procedure (or comparable clinic visit for controls). Steroid dose was kept stable until 22 weeks ("steroid stable phase"), then attempts were made to reduce the dose of oral corticosteroids and ICS gradually over the remaining 30 weeks ("steroid wean phase," weeks 22-36; "reduced steroid phase," weeks 3652). ${ }^{20}$ The AIR 2 study publications do not describe a specific protocol for changes to maintenance medications during follow up. ${ }^{18}$

The schedule for BT procedures was uniform across studies, i.e., three procedures were performed 3 weeks apart. The 6 weeks after the third BT procedure was also considered a part of the "treatment period" in all of the studies.

Detailed evidence tables presenting information on the design of the studies, study inclusion criteria, study population descriptions, findings, risk-of-bias assessments and detailed strength of evidence assessments are located in Appendix C. A table of minimum important differences in asthma-related outcomes is provided in Appendix D. A table of ongoing clinical trials is presented as Appendix E. 


\section{Key Points}

- Patients treated with BT and standard care (medical management) showed statistically greater improvements in asthma control (as measured by the Asthma Control Questionnaire [ACQ]), and quality of life (as measured by the Asthma Quality of Life Questionnaire [AQLQ]) compared with patients undergoing standard care (medical management) only (SOE: low). However, the clinical importance of the changes is unclear.

- Evidence as to whether patients treated with BT and standard care versus standard care alone experienced different rates of severe exacerbations following the treatment period (3 procedures over 6 weeks, followed by an additional 6 weeks) was inconclusive (SOE: insufficient). While rates of mild exacerbations improved to a greater extent in the BT and standard care group than in the standard care only group, the clinical importance of the difference is unclear. (SOE: low).

- Patients treated with BT and standard care used statistically significantly less rescue medication than patients receiving standard care alone, but the clinical importance of the difference is unclear. (SOE: low).

- Patients given BT and standard care had no difference in asthma control scores, as measured by ACQ; in hospitalizations for respiratory symptoms; in use of rescue medication; in number of days rescue medications were required; or in pulmonary physiology measures (forced expiratory volume in 1 second [FEV 1 ] and morning peak expiratory flow $[\mathrm{PEF}]$ ) compared with patients given the sham bronchoscopic procedure and standard care (SOE for all outcomes: low).

- Patients treated with BT and standard care experienced statistically significantly fewer exacerbations (those requiring systemic corticosteroids or doubling of inhaled corticosteroid dose) compared with those receiving the sham bronchoscopic procedure and standard care after the treatment period (3 procedures over 6 weeks, followed by an additional 6 weeks) was complete through the 12-month followup (post-treatment period), but the clinical importance of this difference was unclear (SOE: low).

- Patients treated with BT and standard care had fewer emergency department (ED) visits compared with those receiving the sham bronchoscopic procedure and standard care during the post-treatment period. (SOE: moderate).

- Evidence as to whether patients receiving BT and standard care versus the sham bronchoscopic procedure and standard care had different quality of life (AQLQ) scores was inconclusive (SOE: insufficient). Analysis of results for the intention-to-treat population found no improvement, but analysis of results for the per-protocol population found a difference that may not be clinically important, as it did not achieve the minimum important difference for this measure. A responder analysis (proportion of patients who achieved the minimum important difference) favored the BT and standard care intervention, but this outcome was not prespecified.

- Patients treated with BT developed the following common adverse events: bronchial irritation, chest discomfort, cough, discolored sputum, dyspnea, night awakenings, and wheezing. Serious adverse events occurred more frequently in BT treated patients than in patients receiving the sham bronchoscopic procedure and/or standard care during the 12week treatment period. No deaths were attributed to BT. 


\section{Detailed Synthesis}

\section{Asthma Control}

Low-strength evidence from two RCTs (AIR [n=112] and RISA [n=32]) suggests that patients with moderate to severe asthma (AIR) and severe asthma (RISA) treated with BT and standard care have greater improvement in ACQ scores than patients treated with standard care alone. (We calculated the following from data in the publications: AIR: Standardized mean difference [SMD] in ACQ change score:-0.78, 95\% Confidence Interval [CI]: -1.17 to -0.39; RISA: SMD in ACQ score change=-0.96, 95\% CI: -1.69 to -0.23 . $)^{19,20}$ The clinical significance of this finding is uncertain as the upper bounds of the CI is less than the minimum important difference of 0.5 (See Table D-1 in Appendix D). In contrast, low-strength evidence in the AIR 2 trial comparing BT and standard care with a sham bronchoscopic procedure and standard care found no difference in ACQ scores. (We calculated SMD in ACQ change score:-0.05, 95\% CI: 0.29 to 0.19$).^{18}$

A small retrospective study $(n=25)$ compared 10 patients presenting at a clinic for BT treatment with 15 patients treated at the same institution who enrolled in RCTs of BT. The study suggests that patients treated with BT while enrolled in an RCT at this site saw statistically greater but not clinically important, improvement in ACQ than those treated with BT outside an RCT (clinic: mean change $=-0.5$; 95\% CI: -1.5 to 0.4; RCT: mean change $=-0.8$; 95\% CI:-1.4 to -0.1, [upper bound below the minimum important difference]). ${ }^{24}$ However, due to limitations related to the study design, lack of precision in the results (small sample size), and unknown consistency, insufficient evidence exists to determine whether differences in patient characteristics explain lower rates of success in the clinic patients. For example, patients not in RCTs who received BT were allowed to be on omalizumab, high-dose oral prednisolone, and were not excluded based on frequency of exacerbations, characteristics that could have made some patients ineligible for the RCTs. They were also on higher doses of ICS and were more likely to be at Step 5 than patients enrolled in RCTs.

\section{Exacerbations}

In the AIR RCT, investigators derived exacerbation data from daily diaries that recorded any of the following on two consecutive days during a 2-week period of abstinence from LABA at 3, 6, and 12 months:

- Reduction in the morning PEF of at least 20\% below the average (based on the value measured in the week prior to withdrawal of LABA at baseline)

- Requiring three or more puffs of rescue medication above their average use (based on the average number of puffs per day prior to withdrawal of LABA at baseline)

- $\quad$ Night awakening due to asthma symptoms.

The evidence from the AIR RCT comparing BT and standard care to standard care alone $(n=112)$ was inconclusive regarding differences in rates of severe exacerbations (those requiring systemic corticosteroids or a reduction in PEF of at least 30\% below average) at 12 months. ${ }^{19}$ The study found a statistically significant reduction in mild exacerbations in the BT and standard care group compared to the change in mild exacerbations in the standard care only group (calculated mean difference $=-0.20,95 \% \mathrm{CI}=-0.95$ to -0.15 mild exacerbations per patient per week, or approximately 10 fewer mild exacerbations per year, 95\% CI=3 to 18 fewer per year) at 12 months. We assessed the SOE as low given the study limitations, unknown consistency, and indirectness of measuring exacerbations only while patients were abstaining from LABA for 2 weeks.

The AIR RCT comparing BT and standard care to standard care alone $(n=112)$ reported no difference in rates of hospitalization for respiratory events (3 hospitalizations in 3 patients in BT 
and standard care group vs. 3 hospitalizations in 2 patients in the standard care group) during the post-treatment period (up to 12 months after the last treatment). ${ }^{19}$ The single-arm extension study reported that the rate of hospitalizations "did not get worse compared to year 1 after BT ( $\mathrm{p}=0.15$; repeated measures analysis for proportion of subjects)."22

The RISA RCT comparing BT and standard care to standard care alone $(n=32)$ also found no between-group difference in hospitalizations for respiratory events (BT: 5 hospitalizations vs. standard care: 4 hospitalizations, reported p-value $=0.32$ ) during the post-treatment period (6 weeks after the third BT procedure through 52 weeks). ${ }^{20}$ In the single-arm extension of this study, overall respiratory-related hospitalizations decreased in patients treated with BT and standard care over 5 years compared with baseline, but the change was not statistically significant. ${ }^{23}$ Similarly, while the rate of ED visits over 5 years declined compared to the baseline rate, the change was not statistically significant in this small study. ${ }^{23}$

Low-strength evidence from the AIR 2 trial $(n=288)$ found that patients treated with BT and standard care had fewer severe exacerbations (those requiring systemic corticosteroids or doubling of ICS dose) in the post-treatment period (i.e., 6 weeks after the last BT procedure through 12 months) than patients treated with the sham bronchoscopic procedure and standard care. The posterior probability of superiority (PPS) for this result was 95.5 percent, meeting the study's criterion for statistical significance for this outcome. ${ }^{18}$ However, the FDA statistician noted in his presentation to the Anesthesiology and Respiratory Therapy Devices Panel that the credible interval for the difference crossed 0 (i.e., difference in severe exacerbations per subject per year $=0.48$ in the BT group versus 0.70 in the sham group, credible interval for the difference of -0.31 to 0.52$).{ }^{33}$ Use of the PPS to determine statistical significance is a less stringent criterion than considering the width of the credible interval. After considering the data presented by FDA, we determined that the findings were imprecise.

In the AIR 2 extension study, the reductions in the proportion of BT-treated patients experiencing severe exacerbations in each of the 5 years compared to the proportion in year 1 were not significantly different, since the upper 95\% confidence limits for the differences in proportions were each less than the pre-defined noninferiority margin of 20 percent. However, exacerbations during years 2 to 5 were only ascertained at annual visits and confirmed by medical record review. This method of data collection differed from the use of diaries for recording exacerbations during the original study, and there was no information provided on the completeness or reliability of exacerbation reporting at the annual visits. ${ }^{21}$

The AIR 2 study found no difference in respiratory-related hospitalizations (10.5\% vs. 5.1\%; PPS for the rate in the sham bronchoscopic procedure group being higher than for the BT group, $57.2 \%)$ through 12 months. ${ }^{18}$ Compared with the sham bronchoscopic procedure and standard care, the AIR 2 RCT found that BT and standard care reduced the rate of ED visits for respiratory symptoms by 84 percent, (0.45 visits per subject over 12 months in the sham and standard care group versus 0.13 visits per subject over 12 months in the BT and standard care group; PPS 99.9\%, meeting the study's criterion for statistical significance for this outcome) (moderate SOE). ${ }^{18}$ In the long-term extension of this RCT, ED visits (per subject per year) for respiratory symptoms were reduced in patients treated with BT and standard care by 88 percent over 5 years compared with 12 months before the procedure. ${ }^{21}$ ED visits and hospitalizations were reported by patients only at annual visits during years 2 to 5 .

\section{Other Measures of Health Care Utilization}

Two RCTs suggested that BT and standard care reduced rescue medication use compared with standard care alone at 12 months but the difference did not meet the minimally important difference (MID). ${ }^{19,20}$ Inconclusive evidence from the AIR 2 RCT found no difference between BT with standard care and the sham bronchoscopic procedure with standard care in reducing 
rescue medication or percentage of days with use of rescue medication at the 12-month followup (PPS: $81.3 \%$ and $68.0 \%)^{18}$

\section{Pulmonary Physiology}

The three RCTs with 5-year followup and a retrospective comparative trial reported spirometry data (either $\mathrm{FEV}_{1}$ or PEF). When measured prior to administration of a bronchodilator, $\mathrm{FEV}_{1}$ improved transiently in the patients treated with BT and standard care in the RISA trial $(n=30)$ compared with standard care alone at 22 weeks from baseline (i.e., during the steroid stable phase; between-group mean difference calculated based on reported data: 15.8\%, 95\% CI:1.8: 1.8\% to 29.8\%). However, there was no significant difference between groups in $\mathrm{FEV}_{1}$ when measured postbronchodilator or at a later followup once steroids had been weaned and stabilized (i.e., by 52 weeks). ${ }^{20}$ In the RISA extension, postbronchodilator FEV 1 (\% predicted) did not significantly decline in the group receiving BT and standard care over 5 years of followup or in the control group over 3 years of followup. ${ }^{23}$

In the AIR study $(n=112)$, patients treated with BT and standard care had greater increases in morning and evening PEF compared with standard care alone) from baseline to 12 months; differences in $\mathrm{FEV}_{1}$ (\% predicted, prebronchodilator) were not significant. ${ }^{19}$ This evidence from the AIR and RISA trials was considered inconclusive (SOE: insufficient). Mean FEV 1 (\% predicted, postbronchodilator) remained stable in the control group (i.e. in the 24 of 49 who agreed to long-term followup) over 3 years of followup and in BT-treated patients through the 5year followup. ${ }^{22}$

In the AIR 2 RCT ( $\mathrm{n}=288)$ comparing BT and standard care to the sham bronchoscopic procedure and standard care treatment, there was no change in $\mathrm{FEV}_{1}$ (\% predicted, prebronchodilator) or morning PEF (L/min) between baseline and 12 months (PPS 24.1\% and 80.6\%, respectively) (SOE: low). No statistically significant change in FEV 1 occurred in BTtreated patients from the 12-month through the 5-year followup. ${ }^{18,21}$

In the comparison of clinic patients treated with BT to randomized patients treated with BT, $\mathrm{FEV}_{1}$ (\% predicted, prebronchodilator) change at 12 months was not significantly different. ${ }^{24}$

The AIR RCT found that BT and standard care did not improve airway hyper-responsiveness (defined by a provocative concentration of methacholine required to lower the FEV1 by 20\% (PC20) of less than $8 \mathrm{mg}$ per milliliter), compared with standard care alone between baseline and 12 months. ${ }^{19}$ But in the AIR extension study, airway hyper-responsiveness remained relatively stable in patients treated with BT and standard care while it worsened in the control group treated with standard care alone who agreed to followup in years 2 and $3 .^{22}$

\section{Asthma-Related Quality of Life}

Two studies (AIR and RISA) with low-strength evidence suggested that BT and standard care significantly improved AQLQ scores compared with standard care alone at 12 months from baseline. $^{19,20}$ The mean difference in improvement exceeded the MID in both studies, but the lower bounds of the 95\% CI for the estimate from the AIR study did not exceed the MID. Consequently, we consider the result imprecise and the clinical importance uncertain (SOE: low).

The AIR 2 RCT found a statistically greater increase in AQLQ score with BT and standard care compared with the sham bronchoscopic procedure and standard care in the per-protocol population (PPS, 97.9\%), but not in the intent-to-treat population (PPS, 96.0\% [target PPS for this outcome was 96.4\%]). The difference between groups in the change in AQLQ from baseline to the 12-month followup was less than the MID of 0.5 in both intent-to-treat and per-protocol populations (see Table D-1 in Appendix D). The proportion of patients with improvement in AQLQ score greater than the MID was higher after BT and standard care than after the sham bronchoscopic procedure and standard care (PPS, 99.6\%). However, this was not a prespecified 
outcome, raising concern about the possibility of outcome reporting bias. ${ }^{18}$ Given the differences in results from these three different analytic approaches, we assessed the findings as inconclusive and the SOE as insufficient.

In the observational study comparing two populations undergoing BT, no difference was observed in AQLQ between patients treated with BT in the context of a RCT compared with patients treated with BT outside the RCTs. ${ }^{24}$ However, due to limitations related to the observational nature of the study design, lack of precision in the results, and unknown consistency, insufficient evidence exists to determine whether differences in patient populations factor significantly into patient outcomes in RCTs of BT.

\section{Asthma Symptoms (Secondary Outcome)}

Low-quality evidence from the AIR RCT $(n=112)$ suggests that BT and standard care statistically significantly improved total symptom score from baseline to 12 months compared with standard care alone (between-group mean difference in total symptom score [range 0 to 18] calculated from reported data: $-1.20,95 \% \mathrm{CI}$ : -2.10 to -0.30.$).{ }^{19}$ We did not identify a minimum important difference for this outcome, but calculating the effect size using Hedges g suggests that this is not an important difference $(-0.52,95 \%$ CI -0.91 to -0.12$)$ as the confidence interval is not fully within a margin of 0.2 from 0 .

In the AIR 2 study comparing BT and standard care to the sham bronchoscopic procedure and standard care, self-reported symptom scores improved in both groups from baseline. There were no differences between the treatment conditions at 12-month followup (between-group mean difference in total symptom score [range 0 to 18 ] calculated from reported data: $-0.10,95 \%$ CI: -0.66 to 0.46 ) (SOE: low). ${ }^{18}$

Table 3 presents the findings and SOE ratings for all the comparisons and outcomes assessed.

Table 3. Strength of evidence for bronchial thermoplasty interventions

\begin{tabular}{|c|c|c|c|c|}
\hline Comparison & Outcome $^{a}$ & Conclusion & $\begin{array}{l}\text { Study Design } \\
\text { and Sample Size }\end{array}$ & $\begin{array}{c}\text { Overall } \\
\text { Evidence } \\
\text { Strength } \\
\text { (Limitations }^{b} \text { ) }\end{array}$ \\
\hline \multirow[t]{3}{*}{$\begin{array}{l}\text { BT and } \\
\text { standard care } \\
\text { (medical } \\
\text { management) } \\
\text { vs. standard } \\
\text { care alone }\end{array}$} & Asthma control & $\begin{array}{l}\text { Favors BT, but clinical importance } \\
\text { unclear: ACQ scores improved in patients } \\
\text { who underwent BT compared to those who } \\
\text { received standard medical management, } \\
\text { but the upper bounds of the confidence } \\
\text { interval was less than the MID. }\end{array}$ & $\begin{array}{l}2 \text { RCTs }^{19,20} \\
n=144\end{array}$ & $\begin{array}{l}\text { Low } \\
\text { (Medium study } \\
\text { limitations } \\
\text { Imprecise; MID } \\
\text { not met) }\end{array}$ \\
\hline & $\begin{array}{l}\text { Exacerbations } \\
\text { Severe }\end{array}$ & $\begin{array}{l}\text { Inconclusive: Rates of severe } \\
\text { exacerbations per patient per week did not } \\
\text { vary between treatment conditions. } \\
\text { Exacerbations were counted during } 2 \text { - } \\
\text { week periods at } 3,6 \text { and } 12 \text { months when } \\
\text { LABA were discontinued. }\end{array}$ & $\begin{array}{l}1 \mathrm{RCT}^{19} \\
\mathrm{n}=112\end{array}$ & $\begin{array}{l}\text { Insufficient } \\
\text { (Medium }{ }^{\text {study }} \\
\text { limitations, } \\
\text { indirect } \\
\text { [measured } \\
\text { while off LABA], } \\
\text { unknown } \\
\text { consistency, } \\
\text { Imprecise) } \\
\end{array}$ \\
\hline & $\begin{array}{l}\text { Exacerbations } \\
\text { Mild }\end{array}$ & $\begin{array}{l}\text { Favors BT, but clinical importance } \\
\text { unclear: Rates of mild exacerbations per } \\
\text { patient per week were lower at } 3 \text { and } 12 \\
\text { months but not at } 6 \text { months in patients } \\
\text { who received BT and standard care. } \\
\text { Exacerbations were counted only during 2- } \\
\text { week periods at } 3,6 \text { and } 12 \text { months when } \\
\text { LABA were discontinued. }\end{array}$ & $\begin{array}{l}1 \mathrm{RCT}^{19} \\
\mathrm{n}=112\end{array}$ & $\begin{array}{l}\text { Low } \\
\text { (Medium study } \\
\text { limitations, } \\
\text { indirect } \\
\text { [measured } \\
\text { while off LABA], } \\
\text { unknown } \\
\text { consistency) }\end{array}$ \\
\hline
\end{tabular}




\begin{tabular}{|c|c|c|c|c|}
\hline Comparison & Outcome $^{a}$ & Conclusion & $\begin{array}{c}\text { Study Design } \\
\text { and Sample Size }\end{array}$ & $\begin{array}{c}\text { Overall } \\
\text { Evidence } \\
\text { Strength } \\
\left.\text { (Limitations }^{b}\right) \\
\end{array}$ \\
\hline & $\begin{array}{l}\text { Hospitalizations } \\
\text { (after treatment } \\
\text { period) }\end{array}$ & $\begin{array}{l}\text { No difference: Rates of hospitalizations } \\
\text { were not different in patients who received } \\
\text { BT and standard care versus those treated } \\
\text { with standard care alone. }\end{array}$ & $\begin{array}{l}1 \text { RCT } \\
n=32\end{array}$ & $\begin{array}{l}\text { Low } \\
\text { (Medium }{ }^{\text {study }} \\
\text { limitations } \\
\text { Imprecise) }\end{array}$ \\
\hline & $\begin{array}{l}\text { Health care } \\
\text { utilization (other } \\
\text { than } \\
\text { exacerbations) }\end{array}$ & $\begin{array}{l}\text { Favors BT, but clinical importance } \\
\text { unclear: Use of rescue medication (puffs } \\
\text { per week) was reduced to a greater extent } \\
\text { in the BT group than standard care group } \\
\text { but does not meet the MID criterion } \\
\text { The overall reduction in oral or inhaled } \\
\text { corticosteroid dose was not different } \\
\text { between treatment groups in } 1 \text { small trial. }{ }^{20}\end{array}$ & $\begin{array}{l}2 \text { RCTs }^{19,20} \\
n=144\end{array}$ & $\begin{array}{l}\text { Low } \\
\text { (Medium study }^{c} \\
\text { limitations, } \\
\text { Imprecise) }\end{array}$ \\
\hline & $\begin{array}{l}\text { Pulmonary } \\
\text { physiology: } \\
\text { Spirometry }\end{array}$ & $\begin{array}{l}\text { Inconclusive: In } 1 \text { small trial, BT and } \\
\text { standard care improved FEV } 1 \text { at } 22 \text { weeks } \\
\text { from baseline; the between-group } \\
\text { difference was not significant at } 52 \\
\text { weeks. }^{20} \\
\text { In the other study, patients treated with BT } \\
\text { and standard care had greater increases } \\
\text { in morning and evening peak flow } \\
\text { compared with standard care alone from } \\
\text { baseline to } 12 \text { months. Between-group } \\
\text { change in FEV } V_{1} \text { was not significant. }{ }^{19} \\
\end{array}$ & $\begin{array}{l}2 \operatorname{RCTs}^{19,20} \\
n=144\end{array}$ & $\begin{array}{l}\text { Insufficient } \\
\text { (Medium }{ }^{\mathrm{C}} \text { study } \\
\text { limitations, } \\
\text { Inconsistent, } \\
\text { Imprecise) }\end{array}$ \\
\hline & $\begin{array}{l}\text { Pulmonary } \\
\text { physiology: } \\
\text { Airway hyper- } \\
\text { responsiveness }\end{array}$ & $\begin{array}{l}\text { Inconclusive: Airway hyper- } \\
\text { responsiveness did not vary between } \\
\text { treatment groups }\end{array}$ & $\begin{array}{l}1 \mathrm{RCT}^{19} \\
\mathrm{n}=112\end{array}$ & $\begin{array}{l}\text { Insufficient } \\
\text { (Medium study } \\
\text { limitations, } \\
\text { unknown } \\
\text { consistency, } \\
\text { imprecise) } \\
\end{array}$ \\
\hline & Quality of life & $\begin{array}{l}\text { Favors BT, but clinical importance } \\
\text { unclear: AQLQ scores improved in } \\
\text { patients who underwent BT and received } \\
\text { standard care compared to those who } \\
\text { received standard medical management } \\
\text { alone. The result from the larger study did } \\
\text { not exceed the minimum important } \\
\text { difference criterion (lower bounds of the } \\
95 \% \mathrm{Cl} \text { was less than 0.5). }\end{array}$ & $\begin{array}{l}2 \operatorname{RCTS}^{19,20} \\
n=144\end{array}$ & $\begin{array}{l}\text { Low } \\
\text { (Medium } \text { study } \text { limitations, } \\
\text { Imprecise) }\end{array}$ \\
\hline & $\begin{array}{l}\text { Symptoms } \\
\text { (Secondary } \\
\text { outcome) }\end{array}$ & $\begin{array}{l}\text { Favors BT, but clinical importance } \\
\text { unclear: BT and standard care improved } \\
\text { total symptom score from baseline to } 12 \\
\text { months compared with medical } \\
\text { management alone but the difference may } \\
\text { not be clinically important. }\end{array}$ & $\begin{array}{l}1 \mathrm{RCT}^{19} \\
\mathrm{n}=112\end{array}$ & $\begin{array}{l}\text { Low } \\
\text { (Medium }{ }^{c} \text { study } \\
\text { limitations, } \\
\text { unknown } \\
\text { consistency) }\end{array}$ \\
\hline $\begin{array}{l}\text { BT and } \\
\text { standard care } \\
\text { vs. } \\
\text { the sham }\end{array}$ & Asthma control & $\begin{array}{l}\text { No difference: ACQ scores did not differ } \\
\text { at } 12 \text { months after either BT and standard } \\
\text { care or the sham bronchoscopic procedure } \\
\text { and standard care }\end{array}$ & $\begin{array}{l}1 \mathrm{RCT}^{18} \\
\mathrm{n}=288\end{array}$ & $\begin{array}{l}\text { Low } \\
\text { (unknown } \\
\text { consistency, } \\
\text { imprecise) }\end{array}$ \\
\hline
\end{tabular}




\begin{tabular}{|c|c|c|c|c|}
\hline Comparison & Outcome $^{\mathrm{a}}$ & Conclusion & $\begin{array}{c}\text { Study Design } \\
\text { and Sample Size }\end{array}$ & $\begin{array}{c}\text { Overall } \\
\text { Evidence } \\
\text { Strength } \\
\text { (Limitations }^{b} \text { ) } \\
\end{array}$ \\
\hline \multirow[t]{8}{*}{$\begin{array}{l}\text { bronchoscopic } \\
\text { procedure and } \\
\text { standard care }\end{array}$} & $\begin{array}{l}\text { Exacerbations: } \\
\text { Severe events } \\
\text { (after treatment } \\
\text { period) }\end{array}$ & $\begin{array}{l}\text { Favors BT, but clinical importance } \\
\text { unclear: Patients who underwent BT and } \\
\text { standard care had fewer severe } \\
\text { exacerbations per patient per year than } \\
\text { the sham bronchoscopic procedure and } \\
\text { standard care during weeks } 12 \text { to } 52 \text {. } \\
\text { Fewer patients experienced severe } \\
\text { exacerbations in the BT and standard care } \\
\text { group than in the sham group. }\end{array}$ & $\begin{array}{l}1 \mathrm{RCT}^{18} \\
\mathrm{n}=288\end{array}$ & $\begin{array}{l}\text { Low } \\
\text { (Unknown } \\
\text { consistency, } \\
\text { imprecise } \\
\text { [credible } \\
\text { interval crosses } \\
\text { 0]) }\end{array}$ \\
\hline & $\begin{array}{l}\text { Exacerbations: } \\
\text { Severe events } \\
\text { (during } \\
\text { treatment } \\
\text { period) }\end{array}$ & $\begin{array}{l}\text { Favors the sham bronchoscopic } \\
\text { procedure and standard care: During the } \\
\text { treatment period (up to } 6 \text { weeks following } \\
\text { the } 3^{\text {rd }} \text { BT or sham treatment), the number } \\
\text { of patients experiencing severe } \\
\text { exacerbations was higher in the BT group } \\
\text { than in the sham group. }\end{array}$ & $\begin{array}{l}1 \mathrm{RCT}^{18} \\
\mathrm{n}=288\end{array}$ & $\begin{array}{l}\text { Moderate } \\
\text { (Unknown } \\
\text { consistency) }\end{array}$ \\
\hline & $\begin{array}{l}\text { Exacerbations: } \\
\text { ED visits (after } \\
\text { treatment } \\
\text { period) }\end{array}$ & $\begin{array}{l}\text { Favors BT: Rates of ED visits for } \\
\text { respiratory symptoms were lower over } \\
12 \text { months following BT and standard care } \\
\text { relative to the sham bronchoscopic } \\
\text { procedure and standard care }\end{array}$ & $\begin{array}{l}1 \mathrm{RCT}^{18} \\
\mathrm{n}=288\end{array}$ & $\begin{array}{l}\text { Moderate } \\
\text { (Unknown } \\
\text { consistency) }\end{array}$ \\
\hline & $\begin{array}{l}\text { Exacerbations: } \\
\text { Hospitalizations } \\
\text { (after treatment } \\
\text { period) }\end{array}$ & $\begin{array}{l}\text { No difference: Hospitalizations for } \\
\text { respiratory symptoms at } 12 \text { month } \\
\text { followup }\end{array}$ & $\begin{array}{l}1 \mathrm{RCT}^{18} \\
\mathrm{n}=288\end{array}$ & $\begin{array}{l}\text { Low } \\
\text { (Unknown } \\
\text { consistency, } \\
\text { imprecise) }\end{array}$ \\
\hline & $\begin{array}{l}\text { Exacerbations: } \\
\text { Hospitalizations } \\
\text { (during } \\
\text { treatment } \\
\text { period) }\end{array}$ & $\begin{array}{l}\text { No difference: Hospitalizations for } \\
\text { respiratory symptoms during the treatment } \\
\text { period (up to } 6 \text { weeks following the } 3^{\text {rd }} \text { BT } \\
\text { or sham bronchoscopic procedure) were } \\
\text { higher in the BT group than the sham } \\
\text { group (but the RR crossed } 1 \text { ) }\end{array}$ & $\begin{array}{l}1 \mathrm{RCT}^{18} \\
\mathrm{n}=288\end{array}$ & $\begin{array}{l}\text { Low } \\
\text { (Unknown } \\
\text { consistency, } \\
\text { imprecise) }\end{array}$ \\
\hline & $\begin{array}{l}\text { Health care } \\
\text { utilization: } \\
\text { Rescue } \\
\text { medication } \\
\text { actuations }\end{array}$ & $\begin{array}{l}\text { No difference: Use of rescue medication } \\
\text { at } 12 \text { month followup }\end{array}$ & $\begin{array}{l}1 \mathrm{RCT}^{18} \\
\mathrm{n}=288\end{array}$ & $\begin{array}{l}\text { Low } \\
\text { (Unknown } \\
\text { consistency, } \\
\text { imprecise) }\end{array}$ \\
\hline & $\begin{array}{l}\text { Health care } \\
\text { utilization: } \\
\text { Days rescue } \\
\text { medication } \\
\text { required }\end{array}$ & $\begin{array}{l}\text { No difference: } \% \text { days rescue medication } \\
\text { used at } 12 \text { month followup }\end{array}$ & $\begin{array}{l}1 \mathrm{RCT}^{18} \\
\mathrm{n}=288\end{array}$ & $\begin{array}{l}\text { Low } \\
\text { (Unknown } \\
\text { consistency, } \\
\text { imprecise) }\end{array}$ \\
\hline & $\begin{array}{l}\text { Pulmonary } \\
\text { physiology }\end{array}$ & $\begin{array}{l}\text { No difference: } F E V_{1} \text { and morning peak } \\
\text { flow in patients treated with BT and } \\
\text { standard care compared with the sham } \\
\text { bronchoscopic procedure and standard } \\
\text { care from baseline to } 12 \text { months }\end{array}$ & $\begin{array}{l}1 \mathrm{RCT}^{18} \\
\mathrm{n}=288\end{array}$ & $\begin{array}{l}\text { Low } \\
\text { (Unknown } \\
\text { consistency, } \\
\text { imprecise) }\end{array}$ \\
\hline
\end{tabular}




\begin{tabular}{|c|c|c|c|c|}
\hline Comparison & Outcome $^{a}$ & Conclusion & $\begin{array}{l}\text { Study Design } \\
\text { and Sample Size }\end{array}$ & $\begin{array}{l}\text { Overall } \\
\text { Evidence } \\
\text { Strength } \\
\text { (Limitations }^{b} \text { ) }\end{array}$ \\
\hline & Quality of life & $\begin{array}{l}\text { Inconclusive: } \\
\text { Change in AQLQ scores did not differ in } \\
\text { intent-to-treat patients } 12 \text { months after } \\
\text { either BT and standard care or the sham } \\
\text { bronchoscopic procedure and standard } \\
\text { care } \\
\text { AQLQ improved in per-protocol patients } \\
\text { treated with BT and standard care } \\
\text { compared with the sham bronchoscopic } \\
\text { procedure and standard care at } 12 \\
\text { months. However the difference did not } \\
\text { achieve the minimum important difference. } \\
\text { The proportion of patients with } \\
\text { improvement in AQLQ score greater than } \\
\text { the minimum important difference was } \\
\text { higher after BT and standard care than } \\
\text { after the sham bronchoscopic procedure } \\
\text { and standard care. However, this was not } \\
\text { a prespecified outcome. }\end{array}$ & $\begin{array}{l}\text { 1 } \mathrm{RCT}^{18} \text { intent-to- } \\
\text { treat=288 } \\
\text { per protocol }=268\end{array}$ & $\begin{array}{l}\text { Insufficient } \\
\text { (Medium study } \\
\text { limitations for } \\
\text { per protocol } \\
\text { analysis, } \\
\text { unknown } \\
\text { consistency, } \\
\text { Imprecise [95\% } \\
\text { credible interva } \\
\text { for continuous } \\
\text { measure } \\
\text { crosses 0; } \\
\text { upper bound is } \\
\text { less than MID], } \\
\text { selective } \\
\text { reporting } \\
\text { possible). }\end{array}$ \\
\hline & $\begin{array}{l}\text { Symptoms } \\
\text { (Secondary } \\
\text { outcome) }\end{array}$ & $\begin{array}{l}\text { No difference: Symptom scores improved } \\
\text { over time in both treatment groups but did } \\
\text { not differ as a function of treatment } \\
\text { condition }\end{array}$ & $\begin{array}{l}1 \mathrm{RCT}^{18} \\
\mathrm{n}=288\end{array}$ & $\begin{array}{l}\text { Low } \\
\text { (Unknown } \\
\text { consistency, } \\
\text { imprecise) }\end{array}$ \\
\hline \multirow[t]{5}{*}{$\begin{array}{l}\text { BT in RCT } \\
\text { patients vs. BT } \\
\text { in "real world" } \\
\text { clinic patients }\end{array}$} & Asthma control & $\begin{array}{l}\text { Inconclusive: Although ACQ scores were } \\
\text { significantly better following BT in patients } \\
\text { who were enrolled in the RCTs compared } \\
\text { to the patients from clinic who underwent } \\
\text { BT, this } 1 \text { small nonrandomized study is } \\
\text { insufficient for drawing a conclusion. The } \\
\text { change from baseline in each group was } \\
\text { clinically significant. }\end{array}$ & $\begin{array}{l}1 \text { non-RCT } \\
n=25\end{array}$ & $\begin{array}{l}\text { Insufficient } \\
\text { (High study } \\
\text { limitations, } \\
\text { unknown } \\
\text { consistency, } \\
\text { Imprecise) }\end{array}$ \\
\hline & Exacerbations & $\begin{array}{l}\text { Inconclusive: Rates of exacerbations } \\
\text { were low in both treatment groups and did } \\
\text { not vary statistically }\end{array}$ & $\begin{array}{l}1 \text { non-RCT } \\
n=25\end{array}$ & $\begin{array}{l}\text { Insufficient } \\
\text { (High study } \\
\text { limitations, } \\
\text { unknown } \\
\text { consistency, } \\
\text { Imprecise) }\end{array}$ \\
\hline & $\begin{array}{l}\text { Health care } \\
\text { utilization }\end{array}$ & $\begin{array}{l}\text { Not evaluable: Data on hospitalizations } \\
\text { and medication use not reported in a } \\
\text { comparable manner for treatment groups }\end{array}$ & NA & NA \\
\hline & $\begin{array}{l}\text { Pulmonary } \\
\text { physiology }\end{array}$ & $\begin{array}{l}\text { Inconclusive: } \mathrm{FEV}_{1} \text { did not differ } \\
\text { significantly between groups }\end{array}$ & $\begin{array}{l}1 \text { non-RCT } \\
\mathrm{n}=25\end{array}$ & $\begin{array}{l}\text { Insufficient } \\
\text { (High study } \\
\text { limitations, }^{d} \\
\text { unknown } \\
\text { consistency, } \\
\text { Imprecise) }\end{array}$ \\
\hline & Quality of life & $\begin{array}{l}\text { Inconclusive: AQLQ scores improved to a } \\
\text { clinically significant degree in both } \\
\text { treatment groups; difference between } \\
\text { groups not significantly different, but } \\
\text { sample size was small }\end{array}$ & $\begin{array}{l}1 \text { non-RCT } \\
n=24\end{array}$ & $\begin{array}{l}\text { Insufficient } \\
\text { (High study } \\
\text { limitations, }^{d} \\
\text { unknown } \\
\text { consistency, } \\
\text { Imprecise) }\end{array}$ \\
\hline
\end{tabular}




\begin{tabular}{|c|c|c|c|c|}
\hline Comparison & Outcome $^{a}$ & Conclusion & $\begin{array}{l}\text { Study Design } \\
\text { and Sample Size }\end{array}$ & $\begin{array}{c}\text { Overall } \\
\text { Evidence } \\
\text { Strength } \\
\text { (Limitations }^{\text {b }} \text { ) }\end{array}$ \\
\hline & $\begin{array}{l}\text { Symptoms } \\
\text { (Secondary } \\
\text { outcome) }\end{array}$ & Not evaluable: Not reported & NA & NA \\
\hline
\end{tabular}

${ }^{a}$ Outcomes of Asthma control, Exacerbations, Health care utilization, and Pulmonary physiology as defined by Asthma Outcomes workshop;33 outcomes of Quality of life and Symptoms as defined by study authors.

bStudy limitations derived from Risk of Bias assessments in Appendix C.

'Study limitations: Lack of participant and outcome assessor blinding were the main concerns. Lack of clarity regarding the role of the funding entity was also considered in this domain, but deemed a lesser concern.

${ }^{\mathrm{d}}$ Observational study, retrospective, groups not comparable on baseline characteristics

ACQ: Asthma Control Questionnaire (Range 0-6); AQLQ: Asthma Quality of Life Questionnaire (Range 1-7); BT: bronchial thermoplasty; CI: confidence interval; ED: emergency department; FEV 1 : forced expiratory volume in 1 second; ; LABA: longacting beta-2 agonist; MID: minimallym important difference; NA: not available; PEF: peak expiratory flow; PPS: posterior probability of superiority; RCT: randomized controlled trial; RR: relative risk

\section{Adverse Events and Mortality}

Two RCTs (RISA and AIR) that compared BT to standard care reported that the most common adverse events in patients treated with BT up to six weeks following the third BT procedure (treatment period) were bronchial irritation, chest discomfort, cough, discolored sputum, dyspnea, night awakenings, and wheezing. ${ }^{19,20}$ In both studies, respiratory adverse events were higher in the BT group during the treatment period, but rates did not differ between BT and standard care groups in either study during the post-treatment period through 12-month followup. The RISA RCT $(n=32)$ found that during the 12-week treatment period (i.e., 6 weeks during which 3 BT procedures were performed 3 weeks apart, followed by an additional 6 weeks), 4 of 15 patients treated with BT experienced 7 hospitalizations due to respiratory adverse events compared with no hospitalizations in 17 patients treated with standard care alone. ${ }^{20}$ In the AIR RCT, 4 of 52 patients undergoing BT required 6 hospitalizations during the 12-week treatment period compared to 2 of 48 patients requiring 1 hospitalization each in the standard care control group. ${ }^{19}$

During the AIR extension study, patients from the BT group $(n=45)$ and control group $(n=24)$ were followed for 3 years. During years 2 and 3, there were no significant differences between BT (1.1 to 1.3 events/subject/year) and control group rates (1.2 and 1.3 events/subject/year) of respiratory related events, ascertained at annual visits. ${ }^{22}$

At year 5 of the RISA extension, adverse event rates in patients treated with BT were chest discomfort (8.3\%), cough (0\%), discolored sputum (0\%), and wheezing (8.3\%). ${ }^{23}$ The control group was not included in the 5-year followup. At year 5 of the AIR extension, rates of these common adverse events were bronchial irritation (2.4\%), chest discomfort (4.8\%), cough (4.8\%), discolored sputum (0\%), dyspnea (9.5\%), productive cough (2.4\%), night awakenings (0\%), and wheezing (4.8\%). The control group was not included in the 5-year followup. ${ }^{19,20}$

We supplemented the information on the comparison of adverse events in the AIR 2 trial comparing BT and standard care to a sham bronchoscopic procedure and standard care reported in the journal publication ${ }^{18}$ with data from the FDA presentation to the Anesthesiology and Respiratory Therapy Devices Panel on October 28, 2009. ${ }^{33}$ During the 12-week treatment period, there were 0.20 respiratory adverse events per patient per week in the BT group versus 0.14 in the sham group (169/190 [84\%] of patients in the BT group vs. 74/98 [76\%] in the sham group experienced a respiratory adverse event). Of these, serious respiratory adverse events constituted 0.007 events per patient per week in the BT group versus 0.002 in the sham group (15/190 [8\%] 
of patients in the BT group vs. 2/98 [2\%] in the sham group). The adverse events occurring more frequently during the treatment period in those treated with BT versus those undergoing the. sham bronchoscopic procedure were asthma (defined as multiple symptoms; 52\% vs. 39\%), upper-respiratory-tract infections (20\% vs. 11\%), wheezing (15\% vs. 6\%), dyspnea (11\% vs. $6 \%$ ), lower respiratory tract infection (8\% vs. $2 \%$ ), anxiety (4\% vs. $0 \%$ ), atelectasis (4\% vs. $0 \%$ ), and hemoptysis (3\% vs. 0\%). ${ }^{18,33}$ Among the six patients who experienced hemoptysis, five had mild to moderate hemoptysis that was self-limiting; however, one patient had severe hemoptysis (defined as $>100 \mathrm{cc}$ ) at 31 days following the procedure, and required intervention. ${ }^{33}$

During the treatment period (up to six weeks after last BT or sham bronchoscopic procedure) in the AIR 2 study, 16 of 190 patients in the BT group required 19 hospitalizations for respiratory adverse events versus only 2 of 98 patients in the sham group. The BT-treated patients requiring hospitalization included ten patients hospitalized for worsening of asthma symptoms, two patients for segmental atelectasis, one for lower respiratory tract infection, one for low $\mathrm{FEV}_{1}$, one for aspirated prosthetic tooth, and one for hemoptysis. In the sham-treated subjects, the two hospitalizations during the treatment period were for worsening of asthma. ${ }^{18}$ The investigators state that all adverse events were treated with "standard therapy" (including bronchial artery embolization for hemoptysis). In the 5-year extension that followed the BT arm of the study, respiratory adverse events and asthma symptoms were reduced compared to the first year. Respiratory adverse events occurring at an incidence rate of $\geq 3 \%$ of patients in any of the years 1 through 5 were similar to those listed in the RISA and AIR RCTs above, and included influenza, nasopharyngitis, pneumonia, rhinitis, and sinusitis. There were no cases of pneumothorax, mechanical ventilation, cardiac arrhythmias, or death attributed to BT in the AIR 2 trial. $^{21}$

The nonserious adverse events (e.g., cough, throat irritation, headache, hoarseness) reported in descriptive studies were consistent with those reported in RCTs, although no event rates can be determined from these reports. The serious adverse events reported in the 30 patients described in five case reports and two small case series (including one published in 2006) included five cases of hemoptysis, four cases of atelectasis (often described as due to mucus plugging and requiring hospitalization), two cases of lower respiratory tract infection requiring hospitalization, and one case of lung abscess in the treated lung segment requiring prolonged antibiotic therapy. Additionally, one patient with atelectasis also experienced acute respiratory failure on two occasions, with severe bronchospasm and tachypnea. One patient developed a pulmonary embolism with pleural effusion and bilateral lower-extremity deep venous thrombi following BT. During anticoagulation, she developed a mediastinal hematoma and bloody pleural effusion and was found to have hemorrhaged from a pseudoaneurysm of the bronchial artery thought possibly due to thermal injury from BT. Further details are provided in Appendix Table C-5.

Finally, no deaths were attributed to BT in any of the 15 studies. 


\section{Discussion}

\section{Key Findings and Strength of Evidence}

We identified three primary randomized controlled trials (RCTs, $n=432)^{18-20}$ of bronchial thermoplasty (BT), as well as their associated extension studies $(n=245) .{ }^{21-23}$ One retrospective comparison $^{24}$ and eight descriptive studies $(n=55)^{25-32}$ also reported outcomes associated with BT. Two multicenter RCTs compared BT with standard care (medical management), ${ }^{19,20}$ and one multicenter RCT compared BT to a sham bronchoscopic procedure with standard care continued in both groups. ${ }^{18}$

Compared with standard care alone, the evidence from two RCTs suggests that BT with standard care improved asthma control (defined by the Asthma Control Questionnaire [ACQ], rates of mild exacerbations change from baseline to 12 months), utilization of rescue medication and quality of life (low strength of evidence [SOE]), but the clinical importance of the findings for each of these outcomes is unclear. Rates of hospitalizations for respiratory symptoms were not different for these comparators during the post-treatment period (6 weeks after the third BT treatment through 12-month followup) (SOE: low). The evidence base was insufficient to draw conclusions about BT's effects on severe exacerbations or pulmonary physiologic measures compared with standard care. ${ }^{19,20}$

Compared with the sham bronchoscopic procedure and standard care, the intention-to-treat analysis in a single RCT suggests that BT with standard care had no effect on asthma control (defined as improvement in ACQ from baseline), hospitalizations for respiratory symptoms, rescue medication usage, pulmonary physiologic measures, or other asthma symptom scores (low SOE). Reduced risk of severe exacerbations was suggested (low SOE), but the clinical importance of the degree of the reduction was unclear. Rates of emergency department visits for exacerbations during the post-treatment period were significantly lower in patients receiving the BT and standard care than in those who received the sham bronchoscopic procedure and standard care (moderate SOE) ${ }^{18}$ Serious adverse events attributed to BT occurred during the 12-week treatment period, and no deaths were reported.

\section{Findings Compared to What Is Already Known}

A 2014 Cochrane review ${ }^{34}$ of BT examined the same three RCTs as we did and described the benefits of BT as modest but not clinically significant. Unlike the Cochrane review authors, we did not pool the trial results because of differences in study designs and populations. We also had greater concern about risk of bias in the trials, and therefore graded outcomes more conservatively. These findings are consistent with other systematic reviews and technology assessments. $^{35-37}$

Current clinical practice guidelines suggest a cautious approach to use of BT. For example, the American Thoracic Society (ATS)-European Respiratory Society (ERS) guidelines on definition, evaluation and treatment of severe asthma recommends BT be "performed in adults with severe asthma only in the context of an Institutional Review Board-approved independent systematic registry or a clinical study."38 The authors state that they placed greater weight on avoiding adverse effects and increased use of resources, while noting the uncertainty of benefit in terms of symptoms and quality of life, the lack of data on patients with more severe asthma (forced expiratory volume in 1 second $\left[\mathrm{FEV}_{1]}<60 \%\right.$ of predicted value), and the need for ways to determine which patients might benefit. ${ }^{39}$ Although BT has been approved for use in Japan since 2015, the Japanese Society for Allergology guidelines recommend further study of BT. 
Describing the AIR 2 study, they note that despite the 5-year results, longer term efficacy and safety should still be examined. ${ }^{38}$

The United Kingdom National Institute for Health and Care Excellence (NICE) guidance also calls for longer term safety data, and requires clinicians performing BT to submit patient details to a centralized registry. They state that clinicians should "Ensure that patients understand the uncertainty about the procedure's efficacy and long-term safety, and the possibility of initial worsening of their symptoms, and provide them with clear written information." 40 Similarly, the 2011 British Thoracic Society guideline describes the procedure as "a possible treatment option in selected patients with severe persistent asthma already on maximal therapy, although its place in the treatment of asthma remains to be established." 41 The 2014 Scottish Intercollegiate Guidelines Network also describes BT as a procedure that "may be considered for patients with poorly controlled asthma despite optimal therapy." 42

Finally, the Guideline from the Global Initiative for Asthma states:

[F]or highly-selected adult patients with uncontrolled asthma despite use of recommended therapeutic regimens and referral to an asthma specialty center (Step 5), bronchial thermoplasty is a potential treatment option in some countries. (Evidence level B [RCTs. Limited body of data]) Caution should be used in selecting patients for this procedure as the number of studies is small, and people with chronic sinus disease, frequent chest infections or $\mathrm{FEV}_{1}<60 \%$ predicted were excluded. (Evidence D [panel consensus judgment])"43

\section{Applicability}

Although BT is approved for treating patients with severe persistent asthma, there was heterogeneity in the severity of asthma in the populations included in the three RCTs. The evidence from one of the RCTs is applicable to adult patients with asthma who require $\leq 30 \mathrm{mg}$ per day of prednisone for maintenance while on high-dose inhaled corticosteroids (ICS) and long-acting beta-2 agonists (Research in Severe Asthma Trial [RISA]). ${ }^{20}$ One small trial was designed to compare "real-world" patients, including those with high rates of exacerbations and with no limitation on medication use, and reported that the clinical response was lower and more variable than in the RCTs. ${ }^{24}$ The number of patients in the comparison was too small to draw firm conclusions about the relative benefits of BT in patients who are sicker than those in the RCTs or about the possibility of selection bias in RCTs.

One study enrolled patients on lower doses of ICS (200 mcg/day), but the mean dose at baseline was similar to that in the other trials (Asthma Intervention Research Trial [AIR]). ${ }^{19}$ Some studies restricted enrollment to patients on $<10 \mathrm{mg}$ per day of oral corticosteroid, fewer than three hospitalizations (AIR-2), ${ }^{18}$ fewer than four episodes requiring systemic steroids in the prior year (AIR) and use of no more than four puffs of short-acting beta-2 agonist per day (AIR and AIR-2).

The BT procedure itself appears to be similar across these studies, and was performed in several countries, in settings comparable to those in most bronchoscopy centers. Additional information about the concomitant medical therapy in the BT groups as well as in the control groups would be helpful for translating the findings to practice.

\section{Implications for Clinical and Policy Decisionmaking}

Clinicians whose patients are potential candidates for BT may want to consider the evidence presented in this review, including the highly selected and yet heterogeneous study populations, 
limited improvement in outcomes, and rates of adverse events (including asthma worsening and respiratory tract infections during the treatment period) when determining BT's appropriateness for their patients. Only one small RCT included patients taking more than $10 \mathrm{mg}$ per day of oral corticosteroids and patients with $\mathrm{FEV}_{1}$ as low as 50 percent predicted.

Current guidelines stress the importance of assessing patients' adherence to prescribed therapies and their technique in using inhalers prior to considering BT. One of the U.S. Food and Drug Administration (FDA) presenters to the Anesthesiology and Respiratory Therapy Devices Panel noted that patients in the AIR 2 trial at sites in Brazil, who made up 30 percent of the study population, were all given maintenance medications at no cost. The intention-to-treat analysis of Asthma Quality of Life Questionnaire (AQLQ) results for the patients in Brazil found greater improvement in the group receiving the sham bronchoscopic procedure than in the group undergoing BT. ${ }^{33}$

The primary efficacy endpoint used for BT's regulatory filings with FDA was the AQLQ score change from baseline to the average of 6-, 9-, and 12-month followup from the pivotal AIR 2 sham-controlled trial. ${ }^{33}$ The improvement did not meet the prespecified level of statistical significance in the intention-to-treat population, but did in the per protocol analysis. Nonetheless, the degree of improvement was less than the MID, so it may not be clinically important. While the sham bronchoscopic procedure in this study was associated with some post-procedure respiratory events, there were more adverse events and more events requiring hospitalization in the BT group during the treatment period, although the latter was not a statistically significant difference. Clinicians and patients must balance this risk of adverse events in the treatment period against the evidence for later modest improvements in rates of severe exacerbations and more robust evidence for reduction in emergency department visits for exacerbation.

\section{Limitations of the Systematic Review Process}

The scope of this review may have introduced some important limitations. First, we included only trials with concurrent controls when assessing BT's effectiveness. Similarly, conference abstracts without subsequent full publications were excluded because it is difficult to assess study risk of bias and selective outcome reporting from abstracts, and because results presented in abstracts are frequently different in final publications.

\section{Limitations of the Evidence Base}

This evidence base contains several limitations. Only one of three trials was a blinded, shamcontrolled trial. As seen in our evidence analysis, this study did not show similar findings to the nonblinded, RCTs comparing BT to standard care. Outcome measures were not ascertained using the same assessment procedures. In one study, for example, exacerbations were counted only during 2-week periods when patients were asked to abstain from use of maintenance long-acting beta agonist therapy.

\section{Evidence Gaps}

Several types of evidence gaps could be addressed in future research. Our conclusions for several outcomes were limited by the small number of studies and low numbers of patients. In some instances, the effect sizes had fairly wide confidence intervals (exceeding minimally important differences) which led us to assess the evidence as imprecise. While the RCTs were multicenter, there was only one RCT using a sham control. Given the difference in findings when the sham control was used, and the subjective nature of the majority of outcomes, it would 
be informative to have data from additional studies enrolling similar patients and using the same design.

Two of the three RCTs were assessed as having medium risk of bias, and one low risk of bias. The risk of bias in future studies could be improved by describing both appropriate allocation of treatment and concealment, blinding patients and outcome assessors, and clarifying the role of funders.

Studies using a standard care or medical management control could be improved by reporting concomitant therapies more clearly. Greater uniformity in outcome measures, particularly for exacerbations, would be helpful. In addition, studies could address clinically important differences in outcomes, using data that have been validated by other investigators not involved in the trial (as in Appendix D).

As noted above, only one sham-controlled trial of BT has been published. Given that BT is an invasive procedure and that patients receiving the sham treatment appeared to improve on certain outcomes, further studies using a sham comparison are needed to strengthen the evidence base and help guide appropriate use of BT. Studies could also be undertaken to test BT in other populations, especially patients with poor asthma control who experience higher rates of exacerbations. The studies included in this analysis also did not examine the efficacy of BT stratified by asthma phenotype (e.g., eosinophilic, neutrophilic, paucigranulocytic). Future studies might better elucidate whether BT is more effective in certain asthma phenotypes. As of July 19, 2017, ClinicalTrials.gov listed 18 trials investigating BT that are ongoing, planned, or of unknown status. (See Appendix E.) Most are single-arm observational studies. The randomized trials examine BT administered with traditional bronchoscopy or with other image-guided interventions. No sham-controlled trials are currently registered.

\section{Conclusions}

Three RCTs and several descriptive studies meeting our inclusion criteria have evaluated BT. Based on the available literature, BT may be modestly beneficial in some patients with asthma, but is not without risks in any population. The risk of adverse events is higher during the treatment period and for several weeks afterward. Benefit is typically observed weeks to months after therapy and can last for at least 5 years, after which the duration of effect is unknown. 


\section{References}

1. National Heart, Lung, and Blood Institute. Expert panel report 3: guidelines for the diagnosis and management of asthma. [internet]. Bethesda (MD): National Institutes of Health (NIH); 2007 Jan 01 [accessed 2013 Jun 01]. Available: http://www.nhlbi.nih.gov/guidelines/asthma/

2. Most recent asthma data. [internet]. Atlanta (GA): Centers for Disease Control and Prevention (CDC); [accessed 2016 Jul 05]. Available:

http:www.cdc.gov/asthma/most_recent_data .htm.

3. Trends in asthma morbidity and mortality. Chicago (IL): American Lung Association; 2012 Sep. 26 p. Also available:

http://www.lung.org/assets/documents/resea rch/asthma-trend-report.pdf.

4. The global asthma report 2014. Aukland, New Zealand: Global Asthma Network; 2014. 92 p. Also available: http://www.globalasthmareport.org/resource s/Global_Asthma_Report_2014.pdf.

5. Asthma national health statistics. [internet]. Atlanta (GA): Centers for Disease Control and Prevention (CDC); [accessed $2016 \mathrm{Apr}$ 01]. Available:

http://www.cdc.gov/nchs/fastats/asthma.htm

6. ECRI Institute. Bronchial thermoplasty (Alair System) for treating adult patients with severe symptomatic asthma. Plymouth Meeting (PA): ECRI Institute; 2014 Oct. 34 p. (Emerging Technology Evidence Report).

7. Draft needs assessment report for potential update of the Expert Panel Report-3 (2007): guidelines for the diagnosis and management of asthma. Bethesda (MD): National Heart, Lung, and Blood Institute (NHLBI); 2015 Jan. 14 p. Also available: https://www.nhlbi.nih.gov/sites/www.nhlbi. nih.gov/files/NHLBAC_Asthma-WGReport-2015[1].pdf.
8. The effectiveness of indoor allergen reduction and the role of bronchialthermoplasty in the management of asthma. Rockville (MD): Agency for Healthcare Research and Quality (AHRQ); 2016 Oct 4. 18 p. (Evidence-based Practice Center Systematic Review Protocol; Also available: https://effectivehealthcare.ahrq.gov/ehc/prod ucts/643/2318/asthma-nonpharmacologictreatment-protocol-161004.pdf.

9. Leas B, D'Anci K, Apter A, et al. The effectiveness of indoor allergen reduction and the role of bronchial thermoplasty in the management of asthma. PROSPERO 2017:CRD42017055547\&nbsp;Available from $<$ a href="http://www.crd.york.ac.uk/PROSPER O/display record.asp?ID=CRD4201705554 7" target="PROSPERO">http://www.crd.york. ac.uk/PROSPERO/display record.asp?ID= $\underline{\text { CRD42017055547 }</ \mathrm{a}>}$.

10. Chalmers I, Adams M, Dickersin K, et al. A cohort study of summary reports of controlled trials. JAMA. 1990 Mar 9;263(10):1401-5. PMID: 2304219.

11. Neinstein LS. A review of Society for Adolescent Medicine abstracts and Journal of Adolescent Health Care articles. J Adolesc Health Care. 1987 Mar;8(2):198203. PMID: 3818406.

12. Dundar Y, Dodd S, Williamson P, et al. Case study of the comparison of data from conference abstracts and full-text articles in health technology assessment of rapidly evolving technologies: does it make a difference? Int J Technol Assess Health Care. 2006 Jul;22(3):288-94.

13. De Bellefeuille C, Morrison CA, Tannock IF. The fate of abstracts submitted to a cancer meeting: factors which influence presentation and subsequent publication. Ann Oncol. 1992 Mar;3(3):187-91. PMID: 1586615.

14. Scherer RW, Langenberg P. Full publication of results initially presented in abstracts. In: Cochrane Library [Cochrane methodology review]. Issue 2. Oxford: Update Software; 2001 [accessed 2001 Apr 23]. [35 p].

Available:

http://www.cochrane.org/index.htm. 
15. Yentis SM, Campbell FA, Lerman J. Publication of abstracts presented at anaesthesia meetings. Can J Anaesth. 1993 Jul;40(7):632-4. PMID: 8403137.

16. Marx WF, Cloft HJ, Do HM, et al. The fate of neuroradiologic abstracts presented at national meetings in 1993: rate of subsequent publication in peer-reviewed, indexed journals. AJNR Am J Neuroradiol. 1999 Jun-Jul;20(6):1173-7. PMID: 10445467.

17. Cochrane handbook for systematic reviews of interventions. Version 5.1.0. [database online]. Hoboken (NJ): John Wiley \& Sons, Ltd.; 2011 Mar 20 [accessed 2012 Dec 04]. [various p.]. Available: http://handbook.cochrane.org/.

18. Castro M, Rubin AS, Laviolette M, et al. Effectiveness and safety of bronchial thermoplasty in the treatment of severe asthma: a multicenter, randomized, doubleblind, sham-controlled clinical trial. Am J Respir Crit Care Med. 2010 Jan 15;181(2):116-24. Also available: http://dx.doi.org/10.1164/rccm.2009030354OC. PMID: 19815809.

19. Cox G, Thomson NC, Rubin AS, et al. Asthma control during the year after bronchial thermoplasty. New Eng J Med. 2007 Mar 29;356(13):1327-7. Also available:

http://dx.doi.org/10.1056/NEJMoa064707. PMID: 17392302.

20. Pavord ID, Cox G, Thomson NC, et al. Safety and efficacy of bronchial thermoplasty in symptomatic, severe asthma. Am J Respir Crit Care Med. 2007 Dec 15;176(12):1185-91. Also available: http://dx.doi.org/10.1164/rccm.2007045710C. PMID: 17901415.

21. Wechsler ME, Laviolette M, Rubin AS, et al. Bronchial thermoplasty: long-term safety and effectiveness in patients with severe persistent asthma. J Allergy Clin Immunol. 2013 Dec;132(6):1295-302. Epub 2013 Aug 30. PMID: 23998657.
22. Thomson NC, Rubin AS, Niven RM, et al. Long-term (5 year) safety of bronchial thermoplasty: asthma intervention research (AIR) trial. BMC Pulm Med. 2011 Feb 11;11:8. Also available: http://dx.doi.org/10.1186/1471-2466-11-8. PMID: 21314924.

23. Pavord ID, Thomson NC, Niven RM, et al. Safety of bronchial thermoplasty in patients with severe refractory asthma. Ann Allergy Asthma Immunol. 2013 Nov;111(5):402-7. Also available: http://dx.doi.org/10.1016/j.anai.2013.05.002. PMID: 24125149.

24. Bicknell S, Chaudhuri R, Lee N, et al. Effectiveness of bronchial thermoplasty in severe asthma in 'real life' patients compared with those recruited to clinical trials in the same centre. Ther Adv Respir Dis. 2015 Dec;9(6):267-71. Epub 2015 Aug 24. Also available:

http://dx.doi.org/10.1177/175346581560133 2. PMID: 26307767.

25. McCambridge J, Kruklitis R. Transient bronchial wall thickening after bronchial thermoplasty for asthma. J Bronchology Interv Pulmonol. 2016 Jan;23(1):51-3. Also available:

http://dx.doi.org/10.1097/LBR.0000000000 000240. PMID: 26705012.

26. Nguyen DV, Murin S. Bronchial artery pseudoaneurysm with major hemorrhage after bronchial thermoplasty. Chest. 2016 Apr;149(4):e95-7. Also available: http://dx.doi.org/10.1016/j.chest.2015.09.01 6. PMID: 27055718.

27. Balu A, Ryan D, Niven R. Lung abscess as a complication of bronchial thermoplasty. J Asthma. 2015 Aug 9;52(7):740-2. Also available:

http://dx.doi.org/10.3109/02770903.2015.10 05844. PMID: 25766745.

28. Facciolongo N, Menzella F, Lusuardi M, et al. Recurrent lung atelectasis from fibrin plugs as a very early complication of bronchial thermoplasty: a case report. Multidiscip Respir Med. 2015;10(1):9. Also available: http://dx.doi.org/10.1186/s40248015-0002-7. PMID: 25852934. 
29. Doeing DC, Husain AN, Naureckas ET, et al. Bronchial thermoplasty failure in severe persistent asthma: a case report. J Asthma. 2013 Sep;50(7):799-801. Also available: http://dx.doi.org/10.3109/02770903.2013.79 6974. PMID: 23651158.

30. Mahajan AK, Hogarth DK. Bronchial thermoplasty: therapeutic success in severe asthma associated with persistent airflow obstruction. J Asthma. 2012 Jun;49(5):5279. Also available:

http://dx.doi.org/10.3109/02770903.2012.67 6124. PMID: 22515527.

31. Doeing DC, Mahajan AK, White SR, et al. Safety and feasibility of bronchial thermoplasty in asthma patients with very severe fixed airflow obstruction: a case series. J Asthma. 2013 Mar;50(2):215-8. Also available: http://dx.doi.org/10.3109/02770903.2012.75 1997. PMID: 23252954.

32. Cox G, Miller JD, McWilliams A, et al. Bronchial thermoplasty for asthma. Am J Respir Crit Care Med. 2006 May;173(9):965-9. Also available: http://dx.doi.org/10.1164/rccm.2005071162OC. PMID: 16456145.

33. Anesthesiology and Respiratory Therapy Devices Panel meeting. Alair ${ }^{\circledR}$ Bronchial Thermoplasty System. Asthmatx, Inc. [P080032]. [slide presentation]. Sliver Spring (MD): U.S Food and Drug Administration (FDA); 2009 Oct 28 [90 p]. Available:

https://www.fda.gov/downloads/AdvisoryCo mmittees/CommitteesMeetingMaterials/Med icalDevices/MedicalDevicesAdvisoryComm ittee/AnesthesiologyandRespiratoryTherapy DevicesPanel/UCM286219.pdfAnesthesiolo gy and Respiratory.

34. Torrego A, Sola I, Munoz AM, et al. Bronchial thermoplasty for moderate or severe persistent asthma in adults. Cochrane Database Syst Rev. 2014;3(3):CD009910. PMID: 24585221.

35. Wu Q, Xing Y, Zhou X, et al. Meta-analysis of the efficacy and safety of bronchial thermoplasty in patients with moderate-tosevere persistent asthma. J Int Med Res. 2011;39(1):10-22. PMID: 21672303.
36. Zhou JP, Feng Y, Wang Q, et al. Long-term efficacy and safety of bronchial thermoplasty in patients with moderate-tosevere persistent asthma: a systemic review and meta-analysis. J Asthma. 2016 Jan 2;53(1):94-100. Also available: http://dx.doi.org/10.3109/02770903.2015.10 $\underline{65424}$.

37. Grant MD, Blue Cross Blue Shield Asssociation. Bronchial thermoplasty for treatment of inadequately controlled severe asthma. Technol Eval Cent Asses Program Exec Summ. 2015 Mar;29(12):1-5. PMID: 25962190.

38. Ichinose $\mathrm{M}$, Sugiura $\mathrm{H}$, Nagase $\mathrm{H}$, et al. Japanese guidelines for adult asthma 2017. Allergol Int. 2017 Apr;66(2):163-89. Epub 2017 Feb 11. Also available: http://dx.doi.org/10.1016/j.alit.2016.12.005. PMID: 28196638.

39. Chung KF, Wenzel SE, Brozek JL, et al. International ERS/ATS guidelines on definition, evaluation and treatment of severe asthma. Eur Respir J. 2014 Feb 1;43(2):343-73. Also available: http://dx.doi.org/10.1183/09031936.002020 13. PMID: 24337046.

40. National Institute for Health and Clinical Excellence (NICE). Bronchial thermoplasty for severe asthma. London (UK): National Institute for Health and Clinical Excellence (NICE); 2012 Jan. 9 p. (Interventional procedure guidance; no.419). Also available: http://www.nice.org.uk/nicemedia/live/1277 4/57927/57927.pdf.

41. Du Rand IA, Barber PV, Goldring J, et al. British Thoracic Society guideline for advanced diagnostic and therapeutic flexible bronchoscopy in adults. Thorax. 2011 Nov;66(Suppl 3):iii1-21. Also available: http://thorax.bmj.com/content/66/Suppl_3/iii 1.full.pdf+html. PMID: 21987439.

42. Scottish Intercollegiate Guidelines Network (SIGN), British Thoracic Society. British guideline on the management of asthma. A national clinical guideline. Edinburgh (Scotland): Scottish Intercollegiate Guidelines Network (SIGN); 2014 Oct. 199 p.

43. Global strategy for asthma management and prevention. Vancouver (WA): Global Initiative for Asthma (GINA); 2014. 146 p. 


\section{Abbreviations and Acronyms}

ACQ: Asthma Control Questionnaire

ACT: Asthma Control Test

AHRQ: Agency for Healthcare Research and Quality

AIR: Asthma Intervention Research Trial

AIR 2: Asthma Intervention Research Trial 2

AQLQ: Asthma Quality of Life Questionnaire

BT: bronchial thermoplasty

CI: confidence interval

ED: emergency department

EPC: $\quad$ Evidence-based Practice Center

EPR: Expert Panel Report

FDA: U.S. Food and Drug

Administration

$\mathrm{FEV}_{1}$ : forced expiratory volume in one second

KQ: $\quad$ Key Question

GRADE: Grading of Recommendations Assessment, Development and Evaluation
MID: minimally important difference

NAEPP: National Asthma Education and Prevention Program

NHLBI: National Heart, Lung, and Blood Institutes

PEF: peak expiratory flow

PICOTS: patient populations, interventions, comparators, outcomes, timing, and settings

PPS: $\quad$ posterior probability of superiority

RCT: $\quad$ randomized clinical trial

RISA: $\quad$ Research in Severe Asthma Trial

SOE: $\quad$ strength of evidence

TEP: $\quad$ Technical Expert Panel 


\section{Appendix A. Search Strategies}

\section{Resources Searched}

ECRI Institute information specialists searched the following databases for relevant information. Search terms and strategies for each resource appear below.

Table A-1. Databases searched

\begin{tabular}{|c|c|c|}
\hline Name & Date Limits & Platform/Provider \\
\hline $\begin{array}{l}\text { The Cochrane Central Register of } \\
\text { Controlled Trials (CENTRAL) }\end{array}$ & Inception [1999] through April 20, 2017 & Wiley \\
\hline $\begin{array}{l}\text { The Cochrane Database of Systematic } \\
\text { Reviews (Cochrane Reviews) }\end{array}$ & Inception [1999] through April 20, 2017 & Wiley \\
\hline $\begin{array}{l}\text { Cumulative Index of Nursing and Allied } \\
\text { Health Literature (CINAHL) }\end{array}$ & Inception [1981] through April 20, 2017 & EBSCOhost \\
\hline $\begin{array}{l}\text { Database of Abstracts of Reviews of Effects } \\
\text { (DARE) (part of the Cochrane Library) }\end{array}$ & Inception [1999] through April 20, 2017 & Wiley \\
\hline EMBASE (Excerpta Medica) & Inception [1966] through April 20, 2017 & Embase.com \\
\hline $\begin{array}{l}\text { Health Technology Assessment Database } \\
\text { (HTA) (part of the Cochrane Library) }\end{array}$ & Inception [1999] through April 20, 2017 & Wiley \\
\hline MEDLINE & Inception [1966] through April 20, 2017 & Embase.com \\
\hline PUBMED (In Process citations) & Inception [1966] through April 20, 2017 & NLM \\
\hline $\begin{array}{l}\text { U.K. National Health Service Economic } \\
\text { Evaluation Database (NHS EED) (part of } \\
\text { the Cochrane Library) }\end{array}$ & Inception [1999] through April 20, 2017 & Wiley \\
\hline \multicolumn{3}{|l|}{ Associations and Societies } \\
\hline $\begin{array}{l}\text { American Academy of Allergy, Asthma, and } \\
\text { Immunology }\end{array}$ & June 29, 2016 & https://www.aaaai.org/ \\
\hline Asthma and Allergy Foundation of America & June 30,2016 & http://www.aafa.org/ \\
\hline $\begin{array}{l}\text { American College of Allergy, Asthma, and } \\
\text { Immunology }\end{array}$ & June 29,2016 & http://acaai.org/ \\
\hline $\begin{array}{l}\text { Agency for Healthcare Research and } \\
\text { Quality Technology Assessment Program }\end{array}$ & June 29, 2016 & $\frac{\text { http://www.ahrq.gov/resea }}{\text { rch/findings/ta/index.html }}$ \\
\hline American Lung Association & June 29, 2016 & http://www.lung.org/ \\
\hline American Thoracic Society & June 29,2016 & https://www.thoracic.org/ \\
\hline Centers for Disease Control and Prevention & June 28,2016 & https://www.cdc.gov/ \\
\hline National Academy of Medicine & June 28,2016 & https://nam.edu/ \\
\hline National Heart, Lung, and Blood Institute & June 30, 2016 & https://www.nhlbi.nih.gov/ \\
\hline \multicolumn{3}{|l|}{ Other Gray Literature Resources } \\
\hline ClinicalTrials.gov & Searched April 20, 2017 & $\mathrm{NIH}$ \\
\hline $\begin{array}{l}\text { Centers for Medicare and Medicaid (CMS) - } \\
\text { Medicare Coverage Database }\end{array}$ & Searched July 14, 2016 & CMS \\
\hline ECRI Institute Library Catalog & Searched June 24, 2016 & ECRI Institute \\
\hline ECRI Institute Members Website & Searched June 24, 2016 & ECRI Institute \\
\hline Health Devices & Searched June 24, 2016 & ECRI Institute \\
\hline Healthcare Standards & Searched June 24, 2016 & ECRI Institute \\
\hline Internet & Searched June 27, 2016 & Google; Bing \\
\hline Manufacturers & Searched June 24, 2016 & Boston Scientific \\
\hline Medscape & Searched June 22, 2016 & WebMD \\
\hline National Guideline Clearinghouse ${ }^{\mathrm{TM}}$ & Searched June 24, 2016 & AHRQ \\
\hline $\begin{array}{l}\text { National Institute for Health and Care } \\
\text { Excellence, U.K. }\end{array}$ & Searched June 24, 2016 & NHS \\
\hline $\begin{array}{l}\text { TRIP (Turning Research Into Practice) } \\
\text { Database }\end{array}$ & Searched June 27, 2016 & Trip Database, Ltd. \\
\hline $\begin{array}{l}\text { U.S. Food and Drug Administration (FDA), } \\
\text { including Medical Device databases }\end{array}$ & Searched April 20, 2017 & FDA \\
\hline
\end{tabular}




\section{Reimbursement}

The following Web sites were searched for reimbursement policies: Aetna, Anthem BCBS, BCBS Florida, BCBS of Illinois, BCBS of Texas, BCBS of California, CIGNA, Humana, United Healthcare, Regence.

\section{Hand Searches of Journal and Gray Literature}

Journals and supplements maintained in ECRI Institute's collections were routinely reviewed. Nonjournal publications from professional organizations, private agencies, and government agencies were also screened. Other mechanisms used to retrieve additional relevant information included review of bibliographies/reference lists from peer-reviewed and gray literature. (Gray literature consists of reports, studies, articles, and monographs produced by federal and local government agencies, private organizations, educational facilities, consulting firms, and corporations. These documents do not appear in the peer-reviewed journal literature.)

\section{Topic-Specific Search Terms}

The search strategies employed combinations of free-text keywords as well as controlled vocabulary terms including (but not limited to) the following concepts. Strategies for each bibliographic database follow this table.

Table A-2. Topic-specific search terms

\begin{tabular}{|c|c|c|}
\hline Concept & Controlled Vocabulary & Keywords \\
\hline Asthma & $\begin{array}{l}\text { EMBASE (EMTREE) } \\
\text { asthma/exp } \\
\text { 'allergic asthma'/exp } \\
\text { 'asthmatic state'/exp } \\
\text { 'extrinsic asthma'/exp } \\
\text { 'intrinsic asthma'/exp } \\
\text { 'mild intermittent asthma'/exp } \\
\text { 'mild persistent asthma'/exp } \\
\text { 'nocturnal asthma'/exp } \\
\text { 'occupational asthma'/exp } \\
\text { 'severe persistent asthma'/exp } \\
\text { MEDLINE/PubMed(MeSH) } \\
\text { Asthma[mh] } \\
\text { CINAHL } \\
\text { (MH "Asthma+") } \\
\text { (MH "Asthma, Occupational") }\end{array}$ & Asthma* \\
\hline
\end{tabular}




\begin{tabular}{|c|c|c|}
\hline Concept & Controlled Vocabulary & Keywords \\
\hline General Allergy terms & $\begin{array}{l}\text { EMBASE (EMTREE) } \\
\text { allergen/exp } \\
\text { 'disease exacerbation'/exp } \\
\text { 'environmental exposure'/exp } \\
\text { 'health hazard'/exp } \\
\text { MEDLINE/PubMed (MeSH) } \\
\text { Allergens[mh] } \\
\text { "environmental exposure"[mh] } \\
\text { CINAHL } \\
\text { (MH "Allergens+") } \\
\text { (MH "Disease Exacerbation") } \\
\text { (MH "Environmental Exposure+") }\end{array}$ & $\begin{array}{l}\text { Allergen } \\
\text { exacerbation } \\
\text { exacerbate } \\
\text { irritant } \\
\text { sensitive } \\
\text { sensitivity } \\
\text { trigger }\end{array}$ \\
\hline Bronchial Thermoplasty & $\begin{array}{l}\text { EMBASE (EMTREE) } \\
\text { 'bronchial thermoplasty device'/exp } \\
\text { MEDLINE/PubMed (MeSH) } \\
\text { No equivalent MeSH terms } \\
\text { CINAHL } \\
\text { No equivalent controlled term }\end{array}$ & $\begin{array}{l}\text { Alair* } \\
\text { asthmatx } \\
\text { Bronchial thermoplasty } \\
\text { bronchiothermoplasty }\end{array}$ \\
\hline Bronchial Disease & $\begin{array}{l}\text { EMBASE (EMTREE) } \\
\text { bronchoscopy/exp } \\
\text { bronchoscope/exp } \\
\text { bronchoconstriction/exp } \\
\text { bronchospasm/exp } \\
\text { 'bronchus disease'/exp } \\
\text { bronchus/exp } \\
\text { bronchoplasty/exp } \\
\text { 'airway smooth muscle cell'/exp } \\
\text { MEDLINE/PubMed (MeSH) } \\
\text { bronchoscopy[mh] } \\
\text { bronchoscopes[mh] } \\
\text { bronchoconstriction[mh] or } \\
\text { "bronchial spasm"[mh] } \\
\text { "bronchial diseases"[mh] } \\
\text { bronchi[mh] } \\
\text { CINAHL } \\
\text { (MH "Bronchoscopy") } \\
\text { (MH "Bronchoconstriction") } \\
\text { (MH "Bronchial Diseases+") } \\
\text { (MH "Bronchial Spasm") } \\
\text { (MH "Bronchi+") }\end{array}$ & $\begin{array}{l}\text { airway smooth muscle } \\
\text { bronchial constriction } \\
\text { bronchial spasm } \\
\text { bronchoscope } \\
\text { bronchoconstriction } \\
\text { bronchospasm } \\
\text { bronchus constriction } \\
\text { bronchus spasm }\end{array}$ \\
\hline
\end{tabular}




\begin{tabular}{|l|l|l|}
\hline \multicolumn{1}{|c|}{ Concept } & \multicolumn{1}{|c|}{ Controlled Vocabulary } & \multicolumn{1}{c|}{ Keywords } \\
\hline \hline $\begin{array}{l}\text { Radiofrequency ablation } \\
\text { terms }\end{array}$ & $\begin{array}{l}\text { EMBASE (EMTREE) } \\
\text { 'radiofrequency ablation'/exp } \\
\text { 'radiofrequency ablation device'/exp } \\
\text { 'catheter ablation'/exp } \\
\text { 'pulsed radiofrequency treatment'/exp } \\
\text { MEDLINE/PubMed (MeSH) } \\
\text { "Catheter Ablation"[mh] } \\
\text { "Pulsed Radiofrequency Treatment"[mh] }\end{array}$ & $\begin{array}{l}\text { catheter ablation } \\
\text { heat ablation } \\
\text { radiofrequency ablation } \\
\text { rf ablation } \\
\text { thermal ablation } \\
\text { thermoplasty }\end{array}$ \\
& $\begin{array}{l}\text { CINAHL } \\
\text { (MH "Catheter Ablation") }\end{array}$ & \\
\hline
\end{tabular}




\section{Search Strategies}

Table A-3. Embase/MEDLINE

\begin{tabular}{|c|c|c|}
\hline $\begin{array}{c}\text { Set } \\
\text { Number }\end{array}$ & Concept & Search Statement \\
\hline 1 & $\begin{array}{l}\text { Bronchial } \\
\text { Thermoplasty }\end{array}$ & $\begin{array}{l}\text { 'bronchial thermoplasty device'/exp OR Alair* OR bronchothermoplast* OR } \\
\text { asthmatx* OR bronchiothermoplast* OR (bronchial AND thermoplast*) }\end{array}$ \\
\hline 2 & Asthma & asthma/exp OR asthma* \\
\hline 3 & Bronchial disease & $\begin{array}{l}\text { 'bronchoscopy'/exp OR 'bronchoscope'/exp OR 'bronchoconstriction'/exp OR } \\
\text { 'bronchospasm'/exp OR 'bronchus disease'/exp OR 'bronchus'/exp OR } \\
\text { 'bronchoplasty'/exp OR 'airway smooth muscle cell'/exp OR bronchoscop* OR } \\
\text { bronchoconstrict* OR bronchospasm* OR ((bronchial OR bronchus OR } \\
\text { bronchi) NEAR/4 (constrict OR spasm*)) OR "airway smooth muscle" }\end{array}$ \\
\hline 4 & $\begin{array}{l}\text { Combine Sets - } \\
\text { asthma and/or } \\
\text { bronchial disease }\end{array}$ & 2 OR 3 \\
\hline 5 & $\begin{array}{l}\text { Radiofrequency } \\
\text { ablation terms }\end{array}$ & $\begin{array}{l}\text { 'radiofrequency ablation'/exp OR 'radiofrequency ablation device'/exp OR } \\
\text { 'catheter ablation'/exp OR 'pulsed radiofrequency treatment'/exp OR } \\
\text { thermoplast* OR ((radiofrequency OR thermal OR heat OR catheter* OR "RF") } \\
\text { NEAR/4 ablat*) }\end{array}$ \\
\hline 6 & Combine sets & 4 AND 5 \\
\hline 7 & Combine sets & 1 OR 6 \\
\hline 8 & $\begin{array}{l}\text { Remove unwanted } \\
\text { publication types }\end{array}$ & $\begin{array}{l}7 \text { NOT (abstract:nc OR annual:nc OR book/de OR conference:nc OR } \\
\text { 'conference abstract':it OR 'conference paper'/de OR 'conference paper':it OR } \\
\text { 'conference proceeding':pt OR 'conference review':it OR congress:nc OR } \\
\text { editorial/de OR editorial:it OR erratum/de OR letter:it OR note/de OR note:it OR } \\
\text { meeting:nc OR sessions:nc OR 'short survey'/de OR symposium:nc) }\end{array}$ \\
\hline 9 & Limit 8 to Humans; & 8 AND [humans]/lim \\
\hline
\end{tabular}

\section{EMBASE.com Syntax:}

* $\quad=$ truncation character (wildcard)

$\mathrm{NEAR} / n=$ search terms within a specified number $(n)$ of words from each other in any order

$\mathrm{NEXT} / n=$ search terms within a specified number $(n)$ of words from each other in the order specified

/ $\quad=$ search as a subject heading

$\exp \quad=$ "explodes” controlled vocabulary term (e.g., expands search to all more specific related terms in the vocabulary's hierarchy)

mj = denotes a term that has been searched as a major subject heading

:de $\quad=$ search in the descriptors field (controlled terms and keywords)

:lnk $\quad=$ floating subheading

/lim $=$ limiter

:it,pt. $\quad=$ source item or publication type

:ti. $\quad=$ limit to title

:ti,ab. $\quad=$ limit to title and abstract fields 


\section{PubMed (PreMEDLINE)}

Table A-4. PubMed in process citations

\begin{tabular}{|c|c|c|}
\hline $\begin{array}{c}\text { Set } \\
\text { Number }\end{array}$ & Concept & Search Statement \\
\hline 1 & Bronchial Thermoplasty & $\begin{array}{l}\text { Alair* OR bronchothermoplast* OR asthmatx }{ }^{\star} \text { OR } \\
\text { bronchiothermoplast }^{\star} \text { OR (bronchial AND thermoplast }{ }^{\star} \text { ) }\end{array}$ \\
\hline 2 & Asthma & Asthma[mh] OR asthma* \\
\hline 3 & Bronchial disease & $\begin{array}{l}\text { "Bronchoscopy"[Mesh] OR "Bronchoscopes"[Mesh] OR } \\
\text { "Bronchoconstriction"[Mesh] OR "Bronchial Spasm"[Mesh] OR } \\
\text { "Bronchial Diseases"[Mesh] OR "Bronchi"[Mesh] OR } \\
\text { bronchoscop^ OR bronchoconstrict* OR bronchospasm OR } \\
\text { ((bronchial[tiab] OR bronchus[tiab] OR bronchi[tiab]) AND } \\
\text { (constrict[tiab] OR spasm[tiab])) OR "airway smooth muscle" }\end{array}$ \\
\hline 4 & $\begin{array}{l}\text { Combine Sets - asthma and/or } \\
\text { bronchial disease }\end{array}$ & 2 OR 3 \\
\hline 5 & RF ablation terms & $\begin{array}{l}\text { "Catheter Ablation"[Mesh] OR "Pulsed Radiofrequency } \\
\text { Treatment"[Mesh] OR thermoplast* OR ((radiofrequency OR } \\
\text { thermal OR heat OR catheter*) AND ablat*) OR "rf ablation" }\end{array}$ \\
\hline 6 & Combine sets & 4 AND 5 \\
\hline 7 & Combine sets & 1 OR 6 \\
\hline 8 & Remove unwanted publication types & $\begin{array}{l}7 \text { NOT (comment[pt] OR editorial[pt] OR letter[pt] OR news[pt] } \\
\text { OR "Textbooks" [pt] OR "Book Reviews"[pt]OR "Book } \\
\text { Illustrations"[pt] OR book OR books OR textbook*) }\end{array}$ \\
\hline 9 & In process citations & $\begin{array}{l}8 \text { AND ("inprocess"[sb] OR publisher[sb] OR } \\
\text { pubmednotmedline[sb]) }\end{array}$ \\
\hline
\end{tabular}

\section{PubMed Syntax:}

$\begin{array}{rll}* & \text { truncation character (wildcard) } \\ {[\mathrm{mh}] /[\mathrm{MesH}]} & =\text { controlled vocabulary term } \\ {[\mathrm{sb}]} & = & \text { subset } \\ {[\mathrm{ti}]} & = & \text { limit to title field } \\ {[\mathrm{tiab}]} & = & \text { limit to title and abstract fields } \\ {[\mathrm{tw}]} & = & \text { text word }\end{array}$




\section{CINAHL}

Table A-5. CINAHL

\begin{tabular}{|c|c|c|}
\hline Set Number & Concept & Search Statement \\
\hline 1 & Bronchial Thermoplasty & $\begin{array}{l}\text { Alair* OR bronchothermoplast* OR asthmatx* OR } \\
\text { bronchiothermoplast* OR (bronchial AND thermoplast*) }\end{array}$ \\
\hline 2 & Asthma & (MH "Asthma+") OR asthma* \\
\hline 3 & Bronchial disease & $\begin{array}{l}\text { (MH "Bronchoscopy") OR (MH "Bronchoconstriction") OR (MH } \\
\text { "Bronchial Diseases+") OR (MH "Bronchial Spasm") OR (MH } \\
\text { "Bronchi+") OR bronchoscop* OR bronchoconstrict* OR } \\
\text { bronchospasm OR ((bronchial OR bronchus OR bronchi) } \\
\text { AND (constrict* OR spasm)) OR "airway smooth muscle" }\end{array}$ \\
\hline 4 & $\begin{array}{l}\text { Combine Sets - asthma and/or } \\
\text { bronchial disease }\end{array}$ & 2 OR 3 \\
\hline 5 & RF ablation terms & $\begin{array}{l}\text { (MH "Catheter Ablation") OR thermoplast* OR } \\
\text { ((radiofrequency OR thermal OR heat OR catheter*) AND } \\
\text { ablat*) OR "rf ablation" OR "rf-ablation" }\end{array}$ \\
\hline 6 & Combine sets & 4 AND 5 \\
\hline 7 & Combine sets & 1 OR 6 \\
\hline 8 & Remove Medline records & \\
\hline
\end{tabular}

\section{CINAHL Syntax:}

$\ldots^{+}=$explode

* $=$ truncation character (wildcard)

$\mathrm{N} n=$ search terms within a specified number ( $n$ ) of words from each other in any order

$\mathrm{TI}=$ limit to title field

$\mathrm{AB}=$ limit to title and abstract fields

$\mathrm{MH}=$ MeSH heading

$\mathrm{MJ}=\mathrm{MeSH}$ heading designated as major topic

$\mathrm{PT}=$ publication type 


\section{Appendix B. Excluded Studies}

Ryan DM, Fowler SJ, Niven RM. Reduction in peripheral blood eosinophil counts after bronchial thermoplasty. J Allergy Clin Immunol. 2016 Mar 4. Also available: http://dx.doi.org/10.1016/j.jaci.2015.11.044. PMID: 26953157. Single-arm study; no adverse events

Zhou JP, Feng Y, Wang Q, et al. Long-term efficacy and safety of bronchial thermoplasty in patients with moderate-to-severe persistent asthma: A systemic review and meta-analysis. J Asthma. 2016 Jan 2;53(1):94-100. Also available:

http://dx.doi.org/10.3109/02770903.2015.1065424. Systematic review of included individual studies $^{1-3}$

Ansarin K, Attaran D, Jamaati H, et al. Approach to patients with severe asthma: a consensus statement from the Respiratory Care Experts' Input Forum (RC-EIF), Iran. Tanaffos. 2015;14(2):73-94. PMID: 26528362. Consensus statement

Chakir J, Haj-Salem I, Gras D, et al. Effects of bronchial thermoplasty on airway smooth muscle and collagen deposition in asthma. Ann Am Thorac Soc. 2015 Sep 1;12(11):1612-8. Also available: http://dx.doi.org/10.1513/AnnalsATS.201504-208OC. PMID: 26325484. Single-arm study; no adverse events

Denner DR, Doeing DC, Hogarth DK, et al. Airway inflammation after bronchial thermoplasty for severe asthma. Ann Am Thorac Soc. 2015 Sep 1;12(9):1302-9. Also available: http://dx.doi.org/10.1513/AnnalsATS.201502-082OC. Single-arm study; no adverse events

Dheda K, Koegelenberg CF, Esmail A, et al. Recommendations for the use of bronchial thermoplasty in the management of severe asthma. S Afr Med J. 2015 Sep;105(9):726-32. PMID: 26428967. Systematic review of included individual studies ${ }^{1-3}$

Grant MD, Blue Cross Blue Shield Association. Bronchial thermoplasty for treatment of inadequately controlled severe asthma. Technol Eval Cent Asses Program Exec Summ. 2015 Mar;29(12):1-5. PMID: 25962190. Systematic review of included individual studies ${ }^{1-3}$

Torrego A, Sola I, Munoz AM, et al. Bronchial thermoplasty for moderate or severe persistent asthma in adults. Cochrane Database Syst Rev. 2014;3(3):CD009910. PMID: 2458522.

Systematic review of included individual studies ${ }^{1-3}$

Castro M, Rubin A, Laviolette M, et al. Persistence of effectiveness of bronchial thermoplasty in patients with severe asthma. Ann Allergy Asthma Immunol. 2011 Jul;107(1):65-70. Also available: http://dx.doi.org/10.1016/j.anai.2011.03.005. PMID: 21704887. Superseded by related study with longer followup ${ }^{4}$

Wu Q, Xing Y, Zhou X, et al. Meta-analysis of the efficacy and safety of bronchial thermoplasty in patients with moderate-to-severe persistent asthma. J Int Med Res. 2011;39(1):10-22. PMID: 21672303. Systematic review of included individual studies ${ }^{1-3}$ 


\section{Appendix C. Evidence Tables}

\section{Key Question: What are the benefits and harms of using bronchial thermoplasty in addition to standard treatment for the treatment of adult ( $\geq 18$ years) patients with severe asthma?}

\begin{tabular}{|c|c|c|c|c|c|}
\hline Study & Intervention & Study Design & Study Inclusion Criteria & Demographic Factors & Clinical Characteristics at Baseline \\
\hline $\begin{array}{l}\text { Bicknell et al. } \\
2016^{5}\end{array}$ & $\begin{array}{l}\text { BT in clinic } \\
\text { population } \\
\text { vs. BT in } \\
\text { patients } \\
\text { participating } \\
\text { in RCTs }\end{array}$ & $\begin{array}{l}\text { Type of study: } \\
\text { Retrospective, } \\
\text { comparative } \\
\text { Total population: } \\
\mathrm{N}=10 \text { clinic patients } \\
\mathrm{N}=15 \text { patients from this } \\
\text { site participating in RCTs } \\
\text { of BT (Cox et al. } 2007^{3} \text {, } \\
\text { Pavord et al. } 2007^{2} \text {, and } \\
\text { Castro et al. } 2010^{1} \text { ) } \\
\text { Country: U.K. } \\
\text { Followup: } 1 \text { year }\end{array}$ & $\begin{array}{l}\text { Clinic patient inclusion } \\
\text { criteria described as } \\
\text { similar but not identical to } \\
\text { Cox et al. } 2007^{3} \text {, Pavord } \\
\text { et al. } 2007^{2} \text {, and Castro } \\
\text { et al. } 2010^{1} \\
\text { (RCT participants from } \\
\text { this site met individual } \\
\text { study criteria) } \\
\text { Asthma severity in non- } \\
R C T \text { patients (clinic): } \\
\text { requiring daily ICS at } \\
>1,000 \text { mcg BPD } \\
\text { equivalent and LABA } 100 \\
\text { mcg salmeterol } \\
\text { equivalent; No restriction } \\
\text { on OCS dose, use of } \\
\text { omalizumab, or } \\
\text { frequency of } \\
\text { exacerbations }\end{array}$ & $\begin{array}{l}\text { Age (mean [SD]): } \\
\text { Clinic: } 48 \text { (10) years } \\
\text { RCT: } 43 \text { (12) years } \\
\text { \% Male: } \\
\text { Clinic: } 70 \% \\
\text { RCT: } 67 \% \\
\text { Race: } \\
\text { Clinic: \% NR } \\
\text { RCT: \% NR }\end{array}$ & $\begin{array}{l}\text { Inhaled corticosteroid dose: } \\
\text { Clinic: BDP equivalent } 2,580(\mathrm{SD} 1,425) \mathrm{mcg} / \mathrm{d} \\
\text { RCT: BDP equivalent } 1,757(\mathrm{SD} 1,578) \mathrm{mcg} / \mathrm{d} \\
\text { Oral corticosteroids: } 4 \text { of } 10 \text { clinic patients on oral } \\
\text { prednisolone (dose not reported) } \\
\text { Omalizumab treatment: used in } 2 / 10 \text { clinic patients for } \\
\text { >3years } \\
\text { FEV } 1 \text { (mean [range]): \% predicted: } \\
\text { Clinic: } 72 \%( \pm 16) \\
\text { RCT: } 74 \%( \pm 12) \\
\text { PC } 20 \text { (mg/mI [SD]): } \\
\text { Clinic: NR } \\
\text { RCT: } 0.54(0.84) \\
\text { Asthma severity: British Thoracic Society Steps } 4 \text { and } 5 \\
\text { Comorbidity: NR }\end{array}$ \\
\hline $\begin{array}{l}\text { Pavord et al. } \\
2013^{6} \\
\text { RISA } \\
\text { Extension } \\
\text { Study } \\
\text { 5-year } \\
\text { followup of } \\
\text { Pavord et al. } \\
2007^{2}\end{array}$ & BT alone & $\begin{array}{l}\text { Type of study: } \mathrm{RCT} \\
\text { Extension-1 arm } \\
\text { Total population: } \mathrm{N}=14 \\
\text { BT } \\
\text { Country: U.K. } \\
\text { Followup: } 4 \text { years (years } \\
2-5 \text { ) }\end{array}$ & $\begin{array}{l}\text { Age: } 18-65 \text { y/o } \\
\text { Asthma severity: } \\
\text { severe, requiring daily } \\
\text { ICS at }>750 \text { mcg } \\
\text { fluticasone equivalent } \\
\text { and LABA } 100 \text { mcg } \\
\text { salmeterol equivalent; } \\
\leq 30 \text { mg/d prednisone } \\
\text { equivalent; } \\
\text { Spirometry: } \\
\text { prebronchodilator FEV1 } \\
\geq 50 \% \text { predicted; airway } \\
\text { hyperresponsiveness } \\
\text { (methacholine challenge }\end{array}$ & $\begin{array}{l}\text { Age (mean years [SD]): } \\
38.6 \text { (13.3) } \\
\text { \% Male: } 43 \% \\
\text { Race: } 100 \% \text { Caucasian }\end{array}$ & $\begin{array}{l}\text { Inhaled corticosteroid dose (SD): } \\
\text { BT: fluticasone equivalent 1,166.7 (421) mcg/d } \\
\text { FEV } 1 \text { (mean [SD]): \% predicted: } \\
\text { BT: } 63.5 \%(12.5) \\
\text { PC } 20 \text { (mg/ml geometric mean [range]): } \\
\text { BT: } 0.24(0.1-1.1) \\
\text { Asthma severity: All met the Global Initiative for Asthma } \\
\text { (GINA) criteria for severe persistent asthma } \\
\text { All but one met the American Thoracic Society criteria for } \\
\text { refractory asthma } \\
\text { Comorbidity: Seasonal allergies } 71 \%\end{array}$ \\
\hline
\end{tabular}




\begin{tabular}{|c|c|c|c|c|c|}
\hline Study & Intervention & Study Design & Study Inclusion Criteria & Demographic Factors & Clinical Characteristics at Baseline \\
\hline & & & $\begin{array}{l}\text { or response to } \\
\text { bronchodilator) } \\
\text { Additional: Uncontrolled } \\
\text { symptoms while on } \\
\text { maintenance therapy - } \\
\text { rescue medication used } \\
\text { on } 8 \text { of } 14 \text { days prior to } \\
\text { enrollment or daytime } \\
\text { symptoms on } 10 \text { of } 14 \\
\text { days; nonsmoker } \geq 1 \text { year }\end{array}$ & & \\
\hline $\begin{array}{l}\text { Wechsler } \\
\text { et al. } 2013^{7} \\
\text { AIR } 2 \\
\text { Extension } \\
\text { 5-year } \\
\text { followup of } \\
\text { Castro et al. } \\
2010^{1}\end{array}$ & BT alone & $\begin{array}{l}\text { Type of study: } \mathrm{RCT} \\
\text { Extension-1 arm } \\
\text { Total population: } \mathrm{N}=162 \\
\text { BT } \\
\text { Country: U.S. } \\
\text { Followup: } 5 \text { years }\end{array}$ & $\begin{array}{l}\text { Age: } 18-65 \text { y/o } \\
\text { Asthma severity:, } \\
\text { requiring daily ICS at } \\
>1,000 \text { mcg BPD } \\
\text { equivalent and LABA } 100 \\
\text { mcg salmeterol } \\
\text { equivalent; <10 mg } \\
\text { OCS/day; } \geq 2 \\
\text { symptomatic days in prior } \\
4 \text { weeks } \\
\text { Spirometry: } \\
\text { prebronchodilator FEV1 } \\
\geq 60 \% \text { predicted; } \\
\text { Methacholine PC } 20 \\
<8 m g / m L \\
\text { Additional: AQLQ } \\
\leq 6.25 ;<3 \text { hospitalizations } \\
\text { for asthma; <3 lower } \\
\text { respiratory infection and } \\
<4 \text { pulses of OCS in prior } \\
\text { year }\end{array}$ & $\begin{array}{l}\text { Age (mean years [SD]): } \\
41.5 \text { (11.8) } \\
\text { \% Male: } 42 \% \\
\text { Race: } 82.7 \% \text { Caucasian }\end{array}$ & $\begin{array}{l}\text { Inhaled corticosteroid dose mean (median): } \\
\text { BT: BDP equivalent } 1,960.7(2000) \mathrm{mcg} / \mathrm{d} \\
\text { Control: BDP equivalent } 1,834.8(2,000) \mathrm{mcg} / \mathrm{d} \\
\text { FEV }(\text { mean [SD]): \% predicted: } \\
\text { BT: } 77.8 \%(15.84) \\
\text { PC } 20 \text { (mg/ml geometric mean [range]): } \\
\text { BT: } 0.27(0.21-0.35) \\
\text { Asthma severity: STEPS } 5 \text { or } 6 \\
\text { Comorbidity: NR }\end{array}$ \\
\hline $\begin{array}{l}\text { Thompson } \\
\text { et al. } 2011^{4} \\
\text { AIR Study } \\
\text { extension } \\
\text { 5-year } \\
\text { followup of } \\
\text { Cox et al. } \\
2007^{3}\end{array}$ & $\begin{array}{l}\text { BT vs. } \\
\text { medical } \\
\text { management }\end{array}$ & $\begin{array}{l}\text { Type of study: RCT } \\
\text { Extension-Both arms } \\
\text { Total population: } \\
\mathrm{N}=45 \text { BT } \\
\mathrm{N}=24 \text { control } \\
\text { Country: U.K. } \\
\text { Followup: } 5 \text { years }\end{array}$ & $\begin{array}{l}\text { Age: } 18-65 \text { y/o } \\
\text { Asthma severity: } \\
\text { moderate or severe, } \\
\text { requiring daily ICS at } \\
>200 \text { mcg BPD } \\
\text { equivalent and LABA } 100 \\
\text { mcg salmeterol } \\
\text { equivalent; stable } \\
\text { disease } \\
\text { Spirometry: } \\
\text { prebronchodilator FEV1 } \\
60 \text { to } 85 \% \text { predicted; }\end{array}$ & $\begin{array}{l}\text { Age (mean years [SD]): } \\
\text { BT: } 40.0(11.2) \\
\text { Control: } 40.8(12.1) \\
\text { \% Male: } \\
\text { BT: } 42 \% \\
\text { Control: } 38 \% \\
\text { Race: } \\
\text { BT: } 91 \% \text { Caucasian } \\
\text { Control: } 92 \% \text { Caucasian }\end{array}$ & $\begin{array}{l}\text { Inhaled corticosteroid dose (SD): } \\
\text { BT: BDP equivalent 1,305 (880) mcg/d } \\
\text { Control: BDP equivalent } 1,141(1,053) \mathrm{mcg} / \mathrm{d} \\
\text { FEV } 1 \text { (mean [SD]): \% predicted: } \\
\text { BT: } 72.5 \%(10.9) \\
\text { Control: } 74.9 \%(8.9) \\
\text { PC } 20 \text { (mg/ml geometric mean [range]): } \\
\text { BT: } 0.25(0.2-0.4) \\
\text { Control: } 0.28(0.1-0.6) \\
\text { Asthma severity: NR } \\
\text { Comorbidity: NR }\end{array}$ \\
\hline
\end{tabular}




\begin{tabular}{|c|c|c|c|c|c|}
\hline Study & Intervention & Study Design & Study Inclusion Criteria & Demographic Factors & Clinical Characteristics at Baseline \\
\hline & & & $\begin{array}{l}\text { Methacholine } \mathrm{PC}_{20} \\
<8 \mathrm{mg} / \mathrm{mL} \\
\text { Additional: Worsening of } \\
\mathrm{ACQ} \geq 0.5 \text { when off LABA } \\
\text { for } 2 \text { weeks; }<3 \text { lower } \\
\text { respiratory tract infections } \\
\text { in previous } 12 \text { months, } \\
\text { none in prior } 6 \text { weeks; } \\
\text { nonsmoker } \geq 1 \text { year; }<4 \\
\text { puffs/day short-acting } \\
\text { beta- } 2 \text { agonist }\end{array}$ & & \\
\hline $\begin{array}{l}\text { Castro et al. } \\
2010^{1} \\
\text { AIR } 2 \text { Study }\end{array}$ & BT vs. sham & $\begin{array}{l}\text { Type of study: RCT } \\
\text { Total population: } \\
\text { N=190 BT } \\
\text { N=98 control } \\
\text { Country: } U . S . \\
\text { Followup: } 1 \text { year }\end{array}$ & $\begin{array}{l}\text { Age: } 18-65 \text { y/o } \\
\text { Asthma severity:, } \\
\text { requiring daily ICS at } \\
>1,000 \text { mcg BPD } \\
\text { equivalent and LABA } 100 \\
\text { mcg salmeterol } \\
\text { equivalent; <10 mg } \\
\text { OCS/day; } \geq 2 \\
\text { symptomatic days in prior } \\
4 \text { weeks } \\
\text { Spirometry: } \\
\text { prebronchodilator FEV1 } \\
\geq 60 \% \text { predicted; } \\
\text { Methacholine PC } 20 \\
<8 \text { mg/mL } \\
\text { Additional: AQLQ } \\
\leq 6.25 ;<3 \text { hospitalizations } \\
\text { for asthma; }<3 \text { lower } \\
\text { respiratory infection and } \\
<4 \text { pulses of OCS in prior } \\
\text { year }\end{array}$ & $\begin{array}{l}\text { Age (mean years [SD]): } \\
\text { BT: } 40.7 \text { (11.89) } \\
\text { Control: } 40.6(11.85) \\
\text { \% Male: } \\
\text { BT: } 43 \% \\
\text { Control: } 39 \% \\
\text { Race: } \\
\text { BT: } 80 \% \text { Caucasian } \\
\text { Control: } 74 \% \text { Caucasian }\end{array}$ & 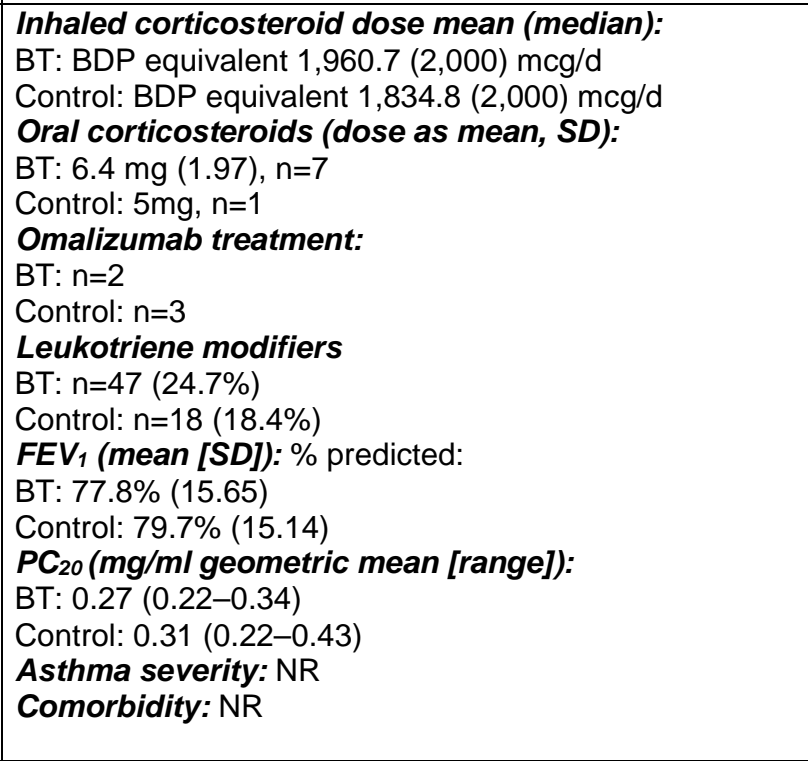 \\
\hline $\begin{array}{l}\text { Cox et al. } \\
2007^{3} \\
\text { AIR Study }\end{array}$ & $\begin{array}{l}\text { BT vs. } \\
\text { medical } \\
\text { management }\end{array}$ & $\begin{array}{l}\text { Type of study: } \mathrm{RCT} \\
\text { Total population: } \\
\mathrm{N}=56 \mathrm{BT} \\
\mathrm{N}=56 \text { control } \\
\text { Country: Canada } \\
\text { Followup: } 1 \text { year }\end{array}$ & $\begin{array}{l}\text { Age: } 18-65 \text { y/o } \\
\text { Asthma severity: } \\
\text { moderate or severe, } \\
\text { requiring daily ICS at } \\
>200 \text { mcg BPD } \\
\text { equivalent and LABA } 100 \\
\text { mcg salmeterol } \\
\text { equivalent; stable } \\
\text { disease } \\
\text { Spirometry: } \\
\text { prebronchodilator FEV1 }\end{array}$ & $\begin{array}{l}\text { Age (mean years [SD]): } \\
\text { BT: } 39.36 \text { (11.18) } \\
\text { Control: } 41.65(11.35) \\
\text { \% Male: } \\
\text { BT: } 44 \% \\
\text { Control: } 43 \% \\
\text { Race: } \\
\text { BT: } 93 \% \text { Caucasian } \\
\text { Control: 93\% Caucasian }\end{array}$ & $\begin{array}{l}\text { Inhaled corticosteroid dose (SD): } \\
\text { BT: BDP equivalent 1,351 (963) mcg/d } \\
\text { Control: BDP equivalent } 1,264(916) \mathrm{mcg} / \mathrm{d} \\
\text { FEV } 1 \text { (mean [SD]): \% predicted: } \\
\text { BT: } 72.65 \%(10.41) \\
\text { Control: } 76.12 \%(9.28) \\
\text { PC }_{20}(\mathbf{m g} / \mathrm{ml}[95 \% \text { Cl]): } \\
\text { BT: } 0.25(0.16-0.40) \\
\text { Control: } 0.35(0.23-0.52) \\
\text { Asthma severity: Moderate persistent- severe persistent } \\
\text { Comorbidity: Seasonal allergies }\end{array}$ \\
\hline
\end{tabular}




\begin{tabular}{|c|c|c|c|c|c|}
\hline Study & Intervention & Study Design & Study Inclusion Criteria & Demographic Factors & Clinical Characteristics at Baseline \\
\hline & & & $\begin{array}{l}60 \text { to } 85 \% \text { predicted; } \\
\mathrm{PC} 20<8 \mathrm{mg} / \mathrm{mL} \\
\text { Additional: Worsening of } \\
\mathrm{ACQ} \geq 0.5 \text { when off } \mathrm{LABA} \\
\text { for } 2 \text { weeks; }<3 \text { lower } \\
\text { respiratory tract infections } \\
\text { in previous } 12 \text { months, } \\
\text { none in prior } 6 \text { weeks and } \\
<4 \text { puffs/day short-acting } \\
\text { beta- } 2 \text { agonist }\end{array}$ & & $\begin{array}{l}\text { BT: } 62 \% \\
\text { Control } 65 \%\end{array}$ \\
\hline $\begin{array}{l}\text { Pavord et al. } \\
2007^{2} \\
\text { RISA Study }\end{array}$ & $\begin{array}{l}\text { BT vs. } \\
\text { medical } \\
\text { management }\end{array}$ & $\begin{array}{l}\text { Type of study: } \mathrm{RCT} \\
\text { Total population: } \\
\mathrm{N}=15 \mathrm{BT} \\
\mathrm{N}=17 \text { control } \\
\text { Country: } \mathrm{U} . \mathrm{K} . \\
\text { Followup: } 1 \text { year }\end{array}$ & $\begin{array}{l}\text { Age: } 18-65 \text { y/o } \\
\text { Asthma severity: } \\
\text { moderate or severe, } \\
\text { requiring daily ICS at } \\
>750 \mathrm{mcg} \text { fluticasone } \\
\text { equivalent and LABA } 100 \\
\text { mcg salmeterol } \\
\text { equivalent; } \leq 30 \mathrm{mg} / \mathrm{d} \\
\text { prednisone equivalent; } \\
\text { Spirometry: } \\
\text { prebronchodilator FEV1 } \\
\geq 50 \% \text { predicted; airway } \\
\text { hyperresponsiveness } \\
\text { (methacholine challenge } \\
\text { or response to } \\
\text { bronchodilator) } \\
\text { Additional: Uncontrolled } \\
\text { symptoms while on } \\
\text { maintenance therapy - } \\
\text { rescue medication used } \\
\text { on } 8 \text { of } 14 \text { days prior to } \\
\text { enrollment or daytime } \\
\text { symptoms on } 10 \text { of } 14 \\
\text { days; nonsmoker } \geq 1 \text { year }\end{array}$ & $\begin{array}{l}\text { Age (mean years [SD]): } \\
\text { BT: } 39.1(13.0) \\
\text { Control: } 42.1(12.6) \\
\text { \% Male: } \\
\text { BT: } 40 \% \\
\text { Control: } 59 \% \\
\text { Race: } \\
\text { BT: } 100 \% \text { Caucasian } \\
\text { Control: } 100 \% \text { Caucasian }\end{array}$ & $\begin{array}{l}\text { Inhaled corticosteroid dose (median): } \\
\text { BT: fluticasone equivalent } 1,166.7(1000) \mathrm{mcg} / \mathrm{d} \\
\text { Control: fluticasone equivalent } 1,058.9(1000) \mathrm{mcg} / \mathrm{d} \\
\text { FEV } 1 \text { (mean [SD]): \% predicted: } \\
\text { BT: } 62.9 \%(12.2) \\
\text { Control: } 66.4 \%(17.8) \\
\text { PC } C_{20} \text { (mg/m/ geometric mean [range]): } \\
\text { BT: } 0.19(0.05-0.76) \\
\text { Control: } 0.31 \text { (0.08-1.26) } \\
\text { Asthma severity: All met the Global Initiative for Asthma } \\
\text { (GINA) criteria for severe persistent asthma } \\
\text { All but one met the American Thoracic Society criteria for } \\
\text { refractory asthma } \\
\text { Comorbidity: Seasonal allergies } \\
\text { BT: } 67 \% \\
\text { Control: } 53 \%\end{array}$ \\
\hline
\end{tabular}

volume; ICS=inhaled corticosteroid; OCS=oral corticosteroid; NR=not reported; $\mathrm{PC}_{20}=$ provocative concentration of methacholine causing a $20 \%$ drop in FEV Study=Research in Severe Asthma Trial Study; SD=standard deviation; U.K.=United Kingdom.; U.S.=United States 
Table C-2 Outcomes of comparative bronchial thermoplasty studies and associated followup studies

\begin{tabular}{|c|c|c|c|c|c|c|c|c|}
\hline Reference & $\begin{array}{l}\text { Attrition } \\
\quad \mathrm{N}, \%\end{array}$ & $\begin{array}{l}\text { Asthma } \\
\text { Control }\end{array}$ & Exacerbations & $\begin{array}{l}\text { Healthcare Utilization } \\
\text { and Costs }\end{array}$ & Quality of Life & $\begin{array}{l}\text { Pulmonary } \\
\text { Physiology }\end{array}$ & Symptoms & Adverse Events \\
\hline $\begin{array}{l}\text { Bicknell et al. } \\
2016^{5}\end{array}$ & $\begin{array}{l}\text { Not } \\
\text { applicable }\end{array}$ & $\begin{array}{l}\text { ACQ7 from } \\
\text { baseline to } \\
12 \text { months } \\
\text { (mean } \\
\text { difference; } \\
\text { MID -0.5) } \\
\text { scores: } \\
\text { Clinic: }-0.5 \\
(-1.5 \text { to } 0.4) \\
\text { RCT: }-0.8 \\
(-1.4 \text { to }-0.1) \\
\text { Clinic vs. } \\
\text { RCT: } p=0.003\end{array}$ & $\begin{array}{l}\text { Exacerbations from } \\
\text { baseline to } \\
12 \text { months (mean } \\
\text { difference; MID 1): } \\
\text { Clinic: }-1 \text { (-2 to } 1) \\
\text { RCT: } 0 \text { (-1 to 0) } \\
\text { Clinic vs. RCT: } \\
\text { p=0.098 } \\
\text { Hospital admissions } \\
\text { in past } 12 \text { months } \\
\text { (MID 1): } \\
\text { Clinic: } 0 \text { (-2 to } 1) \\
\text { RCT: } 0 \text { (0 to 0) } \\
\text { Clinic vs. RCT: } \\
\text { p=0.192 }\end{array}$ & $\begin{array}{l}\text { Hospitalizations: } \\
\text { Clinic: } 3 \text { (2 for asthma; } \\
1 \text { partial lung collapse) } \\
\text { RCT: NR } \\
\text { ICS use BDP } \\
\text { equivalent (mcg [SD]): } \\
\text { Clinic baseline: } 2,980 \\
(1,000) \\
\text { Clinic } 12 \text { months: } 1,757 \\
\text { (1,578) } \\
\text { Clinic change from } \\
\text { baseline: p=0.406 } \\
\text { RCT baseline: } 1,757 \\
\text { (1,578) } \\
\text { RCT } 12 \text { months: NR }\end{array}$ & $\begin{array}{l}\text { AQLQ scores, } \\
\text { change from } \\
\text { baseline } \\
\text { AQLQ (MID } \\
-0.5) \\
\text { Clinic: } 0.7 \\
(-0.1 \text { to } 1.6) \\
\text { RCT: } 1.1(0.4 \text { to } \\
1.7) \\
\text { Clinic vs. RCT: } \\
p=0.085\end{array}$ & $\begin{array}{l}\text { FEV }{ }_{1} \% \text { predicted, } \\
\text { difference from } \\
\text { baseline (range): } \\
\text { Clinic: }-5 \\
\text { (-11 to } 2) \\
\text { RCT: } 6 \text { (-4 to } 15) \\
\text { Clinic vs. RCT: } \\
\text { p=0.632 }\end{array}$ & NR & $\begin{array}{l}\text { Clinic: AEs reported as } \\
\text { similar to events reported } \\
\text { in clinical trials } \\
\text { Clinic: One } \\
\text { hospitalization for a } \\
\text { partial lung collapse } \\
\text { during the periprocedure } \\
\text { period ( } 0-6 \text { weeks) }\end{array}$ \\
\hline
\end{tabular}




\begin{tabular}{|c|c|c|c|c|c|c|c|c|}
\hline Reference & $\begin{array}{l}\text { Attrition } \\
\quad \mathrm{N}, \%\end{array}$ & $\begin{array}{l}\text { Asthma } \\
\text { Control }\end{array}$ & Exacerbations & $\begin{array}{l}\text { Healthcare Utilization } \\
\text { and Costs }\end{array}$ & Quality of Life & $\begin{array}{l}\text { Pulmonary } \\
\text { Physiology }\end{array}$ & Symptoms & Adverse Events \\
\hline $\begin{array}{l}\text { Pavord et al. } \\
2013^{6} \\
\text { RISA } \\
\text { Extension } \\
\text { Study } \\
\text { 5-year } \\
\text { followup of } \\
\text { Pavord et al. } \\
2007^{2}\end{array}$ & 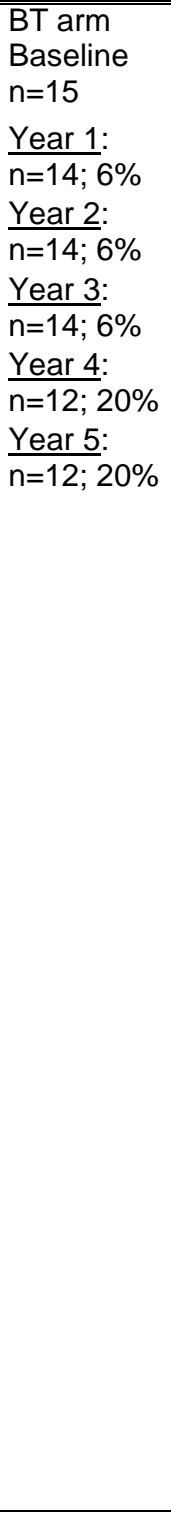 & NR & $\begin{array}{l}\text { Patients requiring } \\
\text { maintenance OCS at } \\
\mathbf{5} \text { years } \\
\text { (baseline } \mathrm{n}=7 \text { ): } \\
\text { Decreased dose: } \mathrm{n}=4 \\
\text { ( } 2 \text { weaned off OCS) } \\
\text { Maintained dose: } \mathrm{n}=2 \\
\text { Increased dose: } \mathrm{n}=1 \\
\text { One patient of those } \\
\text { not taking } \\
\text { maintenance OCS at } \\
\text { baseline ( } \mathrm{n}=7 \text { ) } \\
\text { required maintenance } \\
\text { OCS at year } 5 \\
\text { ED visits per patient } \\
\text { per year: } \\
\text { before BT: } 0.36 \\
5 \text { years after BT: } 0.12 \\
\text { P-value for a } \\
\text { repeated-measures } \\
\text { logistic regression } \\
\text { modeling the } \\
\text { percentage of patients } \\
\text { reporting an ED visit } \\
\text { was } 0.22 \text { for the trend } \\
\text { in the proportion of } \\
\text { patients with ED visits } \\
\text { for respiratory } \\
\text { symptoms across } \\
\text { years } 1 \text { to } 5 \text {. } \\
\text { Respiratory-related } \\
\text { hospitalizations } \\
\text { during followup } \\
\text { period: } \\
11 \text { events in } \\
5 \text { patients from years } \\
2-5 \text { Hospitalizations } \\
\text { for asthma } \\
\text { exacerbations: } \\
7 \text { events ( } 1 \text { lower } \\
\text { respiratory tract } \\
\text { infection, } 1 \text { wheeze, }\end{array}$ & $\begin{array}{l}\text { ICS dose (compared } \\
\text { with baseline): } \\
\text { Unchanged: } n=4 \\
\text { Increased: } n=3 \\
\text { Decreased: } n=5 \\
\text { Maintenance asthma } \\
\text { medication use: } \\
\text { No significant changes } \\
\text { were found in inhaled } \\
\text { maintenance asthma } \\
\text { medication use overall. } \\
\text { LABA dose } 5 \text { years } \\
\text { after BT compared with } \\
\text { baseline: } \\
\text { Unchanged: } n=2 \\
\text { Increased: } n=2 \\
\text { Decreased: } n=2\end{array}$ & $\begin{array}{l}\text { Satisfaction } \\
11 / 12 \\
\text { respondents at } \\
\text { 5-years: } \\
\text { Definitely would } \\
\text { undergo BT } \\
\text { again: n=10 } \\
\text { Would } \\
\text { recommend BT } \\
\text { to a friend or } \\
\text { family member: } \\
\text { n=9 "definitely } \\
\text { yes", n=2 } \\
\text { "probably yes" }\end{array}$ & $\begin{array}{l}\text { Mean pre- } \\
\text { bronchodilator and } \\
\text { post-bronchodilator } \\
\text { FEV }_{1} \text { were unchanged } \\
\text { in the 5-year period } \\
\text { after BT }\end{array}$ & NR & $\begin{array}{l}\text { Respiratory AEs: } \\
\text { \% of patients } \\
\text { experiencing AE: } \\
\text { The rate of respiratory } \\
\text { AEs in people treated } \\
\text { with BT were unchanged } \\
\text { in years } 2 \text { to } 5 \\
\text { Asthma\% Years 1-5: } \\
7.1 \%, 35.7 \%, 50.0 \%, \\
16.7 \%, 41.7 \% \\
\text { Bronchitis Years 1-5: } \\
7.1 \%, 14.3 \%, 21.4 \%, \\
8.3 \%, 8.3 \% \\
\text { Bronchospasm Years } \\
1-5: \\
0 \%, 7.1 \%, 0 \%, 0 \%, 0 \% \\
\text { Chest discomfort Years } \\
1-5: \\
21.4 \%, 0 \%, 0 \%, 8.3 \% \\
\text { Chest pain Years 1-5: } \\
7.1 \%, 0 \%, 5.9 \%, 14.3 \%, \\
8.3 \% \\
\text { Cough Years 1-5: } \\
42.9 \%, 0 \%, 7.1 \%, 0 \%, \\
0 \% \\
\text { Dyspnea Years 1-5: } \\
64.3 \%, 0 \%, 0 \%, 8.3 \%, \\
0 \% \\
\text { Dyspnea exacerbated } \\
\text { Years 1-5: } \\
14.3 \%, 0 \%, 0 \%, 0 \% 0 \% \\
\text { Epistaxis Years 1-5: } \\
14.3 \%, 0 \%, 0 \%, 0 \%, 0 \% \\
\text { Hemoptysis Years 1-5: } \\
7.1 \%, 0 \%, 0 \%, 0 \%, 0 \%, \\
\text { Hoarseness Years 1-5: } \\
7.1 \%, 0 \%, 7.1 \%, 0 \%, 0 \% \\
\text { LRTI Years 1-5: } \\
42.9 \%, 35.7 \%, 28.6 \%, \\
41.7 \%, 58.3 \%\end{array}$ \\
\hline
\end{tabular}




\begin{tabular}{|c|c|c|c|c|c|c|c|c|}
\hline$\overline{\text { Reference }}$ & $\begin{array}{l}\text { Attrition } \\
\mathrm{N}, \%\end{array}$ & $\begin{array}{l}\text { Asthma } \\
\text { Control }\end{array}$ & Exacerbations & $\begin{array}{l}\text { Healthcare Utilization } \\
\text { and Costs }\end{array}$ & Quality of Life & $\begin{array}{l}\text { Pulmonary } \\
\text { Physiology }\end{array}$ & Symptoms & Adverse Events \\
\hline & & & $\begin{array}{l}2 \text { semi-elective for } \\
\text { prophylactic } \\
\text { intravenous infusion } \\
\text { of aminophylline) } \\
1 \text { patient accounted } \\
\text { for } 6 \text { hospitalizations } \\
\text { Respiratory-related } \\
\text { hospitalizations per } \\
\text { patient per year: } \\
12 \text { months before } \\
\text { study: } 0.71 \\
\text { Year 1: } 0.36 \\
\text { Year 2: } 0.43 \\
\text { Year 3: } 0.21 \\
\text { Year 4: } 0.08 \\
\text { Year 5: } 0.08 \\
\text { Overall 5 years after } \\
\text { BT: } 0.23 \text { per patient } \\
\text { per year (68\% } \\
\text { reduction from 12 } \\
\text { months prior to BT) }\end{array}$ & & & & & 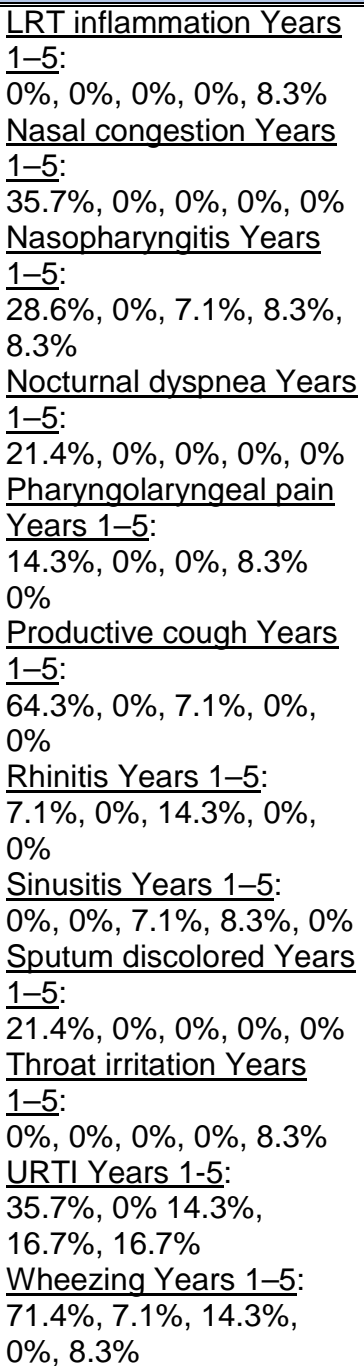 \\
\hline
\end{tabular}




\begin{tabular}{|c|c|c|c|c|c|c|c|c|}
\hline Reference & $\begin{array}{l}\text { Attrition } \\
\mathrm{N}, \%\end{array}$ & $\begin{array}{l}\text { Asthma } \\
\text { Control }\end{array}$ & Exacerbations & $\begin{array}{l}\text { Healthcare Utilization } \\
\text { and Costs }\end{array}$ & Quality of Life & $\begin{array}{l}\text { Pulmonary } \\
\text { Physiology }\end{array}$ & Symptoms & Adverse Events \\
\hline $\begin{array}{l}\text { Wechsler et al. } \\
2013^{7} \\
\text { AIR } 2 \\
\text { Extension } \\
\text { 5-year } \\
\text { followup of } \\
\text { Castro et al. } \\
2010^{1}\end{array}$ & $\begin{array}{l}\text { BT treated } \\
\text { patients } \\
n=162 ; \\
\text { of 190 BT- } \\
\text { treated } \\
\text { patients } \\
\text { from AIR } 2 \\
\text { study, } \\
85.3 \% \\
\text { completed } \\
5 \text {-year } \\
\text { followup } \\
\text { Year 1: } \\
n=181 ; 4 \% \\
\frac{\text { Year 2: }}{n=165 ;} \\
13 \% \\
\frac{\text { Year 3: }}{n=162 ;} \\
14 \% \\
\frac{\text { Year 4: }}{n=159 ;} \\
16 \% \\
\frac{\text { Year 5: }}{n=162 ;} \\
14 \%\end{array}$ & NR & $\begin{array}{l}\text { ED visit for serious } \\
\text { respiratory } \\
\text { symptoms: } \\
\text { Average reduction } 12 \\
\text { months before BT vs. } \\
\text { over the } 5 \text { years after } \\
\text { BT: } 78 \% \\
\text { ED visits: } \\
\text { Average reduction } \\
12 \text { months before BT } \\
\text { vs. over 5 years after } \\
\text { BT: 88\% } \\
\text { Hospitalizations for } \\
\text { respiratory } \\
\text { symptoms } \\
\text { (Events/patient/ } \\
\text { year [95\% CI]): } \\
12 \text { months before BT } \\
0.053 \text { [0.04-0.08] } \\
\text { Year 1: } \\
0.04 \text { [0.025-0.060] } \\
\text { Year: } \\
0.061 \text { [0.042-0.087] } \\
\text { Year } 3: \\
0.068 \text { [0.048-0.096] } \\
\text { Year 4: } \\
0.076 \text { [0.054-0.105] } \\
\text { Year 5: } \\
0.025 \text { [0.014-0.044] } \\
\text { Average over 5 years: } \\
0.053 \text { [0.038-0.073] } \\
\text { The proportion of } \\
\text { respiratory } \\
\text { hospitalizations for } \\
\text { respiratory symptoms } \\
\text { did not increase over } \\
5 \text { years } \\
\text { Severe } \\
\text { exacerbations: } \\
\text { Frequency in years } \\
2-5 \text { compared with }\end{array}$ & 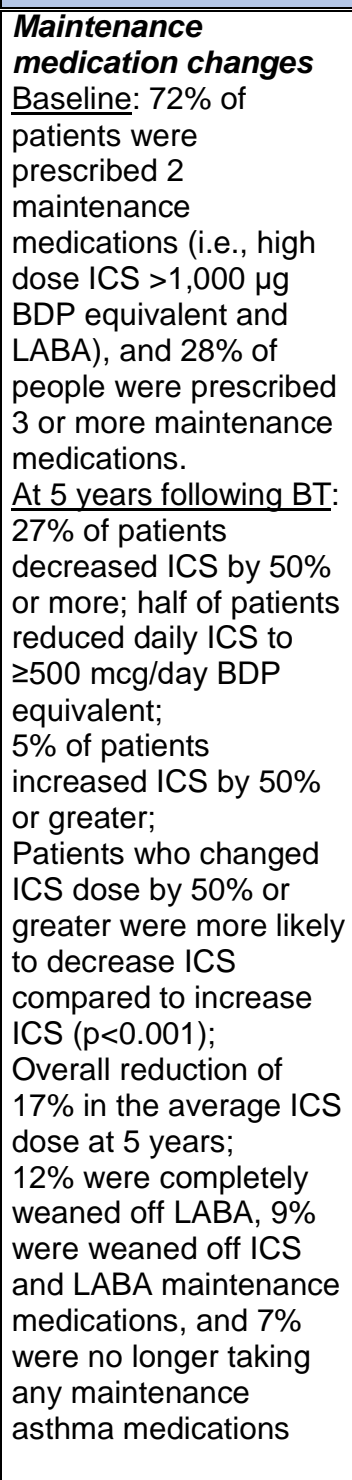 & NR & $\begin{array}{l}\% \text { predicted pre- } \\
\text { bronchodilator FEV } 1 \\
\text { values remained } \\
\text { unchanged over the } \\
5 \text { years } \\
\text { Baseline } \\
\text { BT }(n=190): \\
\text { FEV1 \% } \\
\text { prebronchodilator: } \\
77.8 \pm 15.65 \% \\
\text { At } 5 \text { years following } \\
\text { BT: } \\
\text { BT ( } n=162): \\
\text { FEV1 \% } \\
\text { prebronchodilator: } \\
77.8 \pm 15.84 \\
\% \text { predicted post- } \\
\text { bronchodilator FEV } 1 \\
\text { values remained } \\
\text { unchanged over the } \\
5 \text { years } \\
\text { Baseline } \\
\text { BT ( } n=190): \\
\text { FEV1 \% post- } \\
\text { bronchodilator: } \\
86.1 \pm 15.76 \% \\
\text { At } 5 \text { years following } \\
\text { BT: } \\
\text { BT ( } n=162): \\
\text { FEV1 \% post- } \\
\text { bronchodilator: } \\
85.9 \pm 15.83\end{array}$ & NR & $\begin{array}{l}\text { Respiratory adverse } \\
\text { events occurring in } \\
\geq 3.0 \% \text { of patients in } \\
\text { years } 1 \text { through } 5: \\
\text { Asthma (multiple } \\
\text { symptoms) } \\
\text { Bronchitis } \\
\text { Cough } \\
\text { Influenza } \\
\text { Lower respiratory tract } \\
\text { infections } \\
\text { Nasopharyngitis } \\
\text { Pneumonia } \\
\text { Rhinitis } \\
\text { Sinusitis } \\
\text { Upper respiratory tract } \\
\text { infections } \\
\text { Wheezing } \\
\text { Respiratory AEs } \\
\text { (Events/patient/year } \\
\text { [95\% CI]): } \\
\text { 12 months before BT: NA } \\
\text { Year 1: } 2.02 \\
\text { [1.764-2.318] } \\
\text { Year 2: 1.22 } \\
\text { [1.013-1.465] } \\
\text { Year 3: } 1.25 \\
\text { [1.037-1.499] } \\
\text { Year 4: 1.18 } \\
\text { [0.971-1.424] } \\
\text { Year 5: 0.78 } \\
\text { [0.616-0.982] } \\
\text { Average over } 5 \text { years: } \\
\text { 1.30 [1.149-1.481] } \\
\text { The proportion of } \\
\text { respiratory AEs did not } \\
\text { increase over } 5 \text { years } \\
\text { Asthma AEs } \\
\text { (Events/patient/year } \\
\text { [95\% CI]): } \\
\text { 12 months before BT: NA }\end{array}$ \\
\hline
\end{tabular}




\begin{tabular}{|c|c|c|c|c|c|c|c|c|}
\hline Reference & $\begin{array}{l}\text { Attrition } \\
\mathrm{N}, \%\end{array}$ & $\begin{array}{l}\text { Asthma } \\
\text { Control }\end{array}$ & Exacerbations & $\begin{array}{l}\text { Healthcare Utilization } \\
\text { and Costs }\end{array}$ & Quality of Life & $\begin{array}{l}\text { Pulmonary } \\
\text { Physiology }\end{array}$ & Symptoms & Adverse Events \\
\hline & & & $\begin{array}{l}\text { year } 1 \text { were not } \\
\text { significant } \\
\text { Patients reporting } \\
\text { severe exacerbations } \\
\text { in the year after BT: } \\
30.9 \% \\
12 \text { months before BT: } \\
51.6 \% \\
\text { Reductions } \\
\text { maintained for } 5 \text { years } \\
\text { with an average } \\
\text { decrease of } 44 \% \\
\text { Severe } \\
\text { exacerbations } \\
\text { (matched pairs } \\
\text { analysis n=162 at } \\
\text { years 1, 2, 3, 4, } \\
\text { and 5): } \\
30.9 \%, 23.5 \%, 34.0 \% \text {, } \\
36.4 \%, \text { and } 21.6 \% ; \\
53.1 \% \text { experienced } \\
1 \text { or more } \\
\text { exacerbations } 12 \\
\text { months before BT; } \\
\text { Average reduction } \\
\text { over } 5 \text { years } \\
\text { compared to the } \\
12 \text { months prior to BT: } \\
48 \% \text { (upper 95\% } \\
\text { confidence limit for } \\
\text { Years 2, 3, 4, and } 5 \\
\text { compared to Year 1 } \\
\text { was 0.5, 11.3, 14.0, } \\
\text { and -1.6, respectively; } \\
\text { all less than the } \\
\text { predefined non- } \\
\text { inferiority margin of } \\
20 \% \text { ) }\end{array}$ & & & & & $\begin{array}{l}\text { Year 1: } 0.481 \\
{[0.379-0.609]} \\
\text { Year 2: } 0.461 \\
{[0.357-0.594]} \\
\text { Year 3: } 0.506 \\
{[0.396-0.646]} \\
\text { Year } 4: 0.503 \\
{[0.393-0.644]} \\
\text { Year } 5: 0.321 \\
{[0.236-0.436]} \\
\text { Average over } 5 \text { years: } \\
0.45 \text { [0.374-0.554] } \\
\text { The proportion of asthma } \\
\text { (multiple symptoms) did } \\
\text { not increase over } 5 \text { years }\end{array}$ \\
\hline
\end{tabular}




\begin{tabular}{|c|c|c|c|c|c|c|c|c|}
\hline Reference & $\begin{array}{c}\text { Attrition } \\
\mathrm{N}, \%\end{array}$ & $\begin{array}{l}\text { Asthma } \\
\text { Control }\end{array}$ & Exacerbations & $\begin{array}{c}\text { Healthcare Utilization } \\
\text { and Costs }\end{array}$ & Quality of Life & $\begin{array}{l}\text { Pulmonary } \\
\text { Physiology }\end{array}$ & Symptoms & Adverse Events \\
\hline $\begin{array}{l}\text { Thompson } \\
2011^{4} \\
\text { AIR Study } \\
\text { extension } \\
\text { 5-year } \\
\text { followup of } \\
\text { Cox } 2007^{3}\end{array}$ & $\begin{array}{l}\text { Baseline } \\
\text { BT: } n=52 \\
\text { Control: } \\
\text { n=49 } \\
\text { Year 2: } \\
\text { BT: } n=45 ; \\
13 \% \\
\text { Control: } \\
n=24 ; 51 \% \\
\text { Year 3: } \\
\text { BT: } n=43 ; \\
17 \% \\
\text { Control: } \\
n=21 ; 57 \% \\
\text { Year 4: } \\
\text { BT } n=43 ; \\
17 \% \\
\text { Year } 5: \\
\text { BT: } n=42 ; \\
20 \%\end{array}$ & NR & $\begin{array}{l}\text { Oral corticosteroid } \\
\text { use (high-dose } \\
\text { pulses/patient/year } \\
\text { (\% of patients)): } \\
\text { Year: } \\
\text { BT: } 0.60(24.5 \%) \\
\text { Control: } 0.42(20.8 \%) \\
\text { Year: } \\
\text { BT: } 0.49(24.5 \%) \\
\text { Control: } 0.54 \text { (33.3\%) } \\
\text { Year 3: } \\
\text { BT: 0.33 (25.6\%) } \\
\text { Control: } 0.52(23.8 \%) \\
\text { Year 4: } \\
\text { BT: } 0.63 \text { (27.9\%) } \\
\text { Year 5: } \\
\text { BT: } 0.62 \text { (30.9\%) } \\
\text { Hospitalizations } \\
\text { Year 1: } \\
\text { BT: } 6.7 \% \\
\text { Control: } 0 \% \\
\text { BT vs. control: } p=0.55 \\
\text { Year 2: } \\
\text { BT: } 6.7 \% \\
\text { Control: } 0 \% \\
\text { BT vs. control: } p=0.55 \\
\text { Year 3: } \\
\text { BT: } 2.3 \% \\
\text { Control: } 4.8 \% \\
\text { BT vs. control: } p=1.00 \\
\text { Hospitalizations for } \\
\text { respiratory symptoms } \\
\text { in the BT arm did not } \\
\text { increase over 5-year } \\
\text { followup compared } \\
\text { with year } 1 \text { after BT } \\
\text { (p=0.16; repeated } \\
\text { measures analysis for } \\
\text { proportion of subjects) }\end{array}$ & 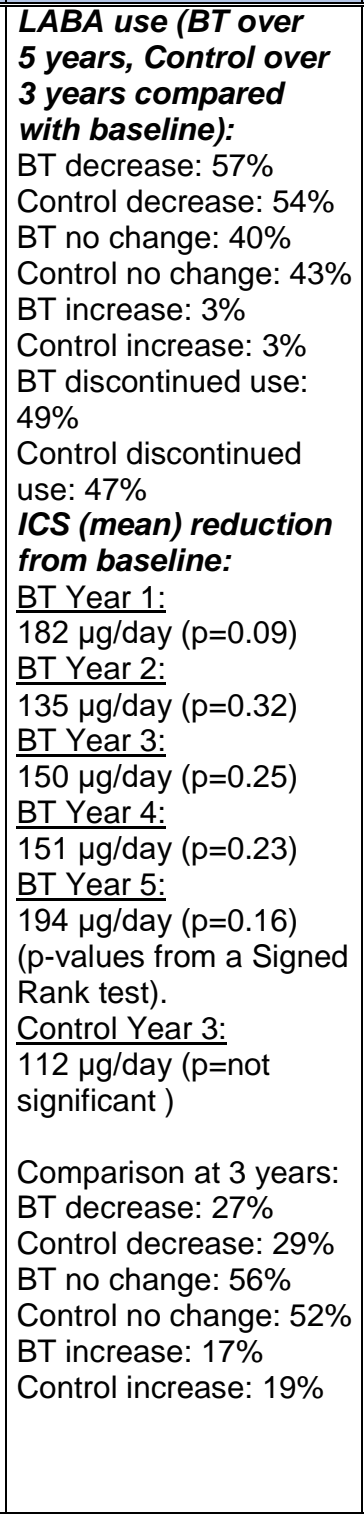 & \begin{tabular}{|c|} 
NR \\
\\
\\
\\
\\
\\
\end{tabular} & $\begin{array}{l}\text { Pulmonary function } \\
\text { tests: } \\
\text { FEV } 1 \text { and } F \text { FC did not } \\
\text { deteriorate over } \\
5 \text { years post-BT } \\
\text { PC20 doublings (SD): } \\
\text { Year 1: } \\
\text { BT: } 1.53(2.29) \\
\text { Control: } 1.00(2.46) \\
\text { BT vs. control: } p=0.378 \\
\text { Year } 2: \\
\text { BT: } 1.21 \text { (2.99) } \\
\text { Control: }-0.47(2.31) \\
\text { BT vs. control: } p=0.024 \\
\text { Year } 3: \\
\text { BT: } 1.31 \text { (2.96) } \\
\text { Control: }-0.44(2.27) \\
\text { BT vs. control: } p=0.025\end{array}$ & None & 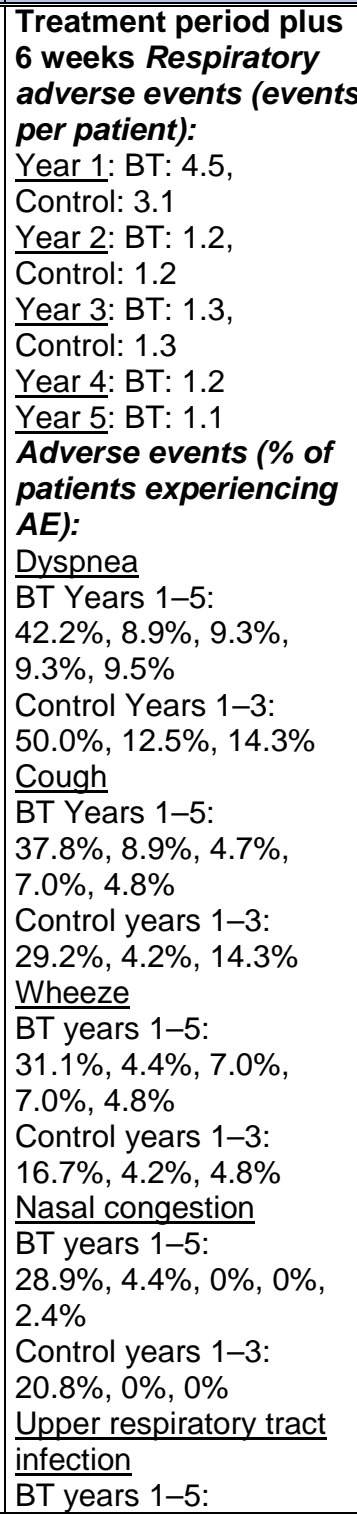 \\
\hline
\end{tabular}




\begin{tabular}{|c|c|c|c|c|c|c|c|c|}
\hline Reference & $\begin{array}{l}\text { Attrition } \\
\mathrm{N}, \%\end{array}$ & $\begin{array}{l}\text { Asthma } \\
\text { Control }\end{array}$ & Exacerbations & $\begin{array}{l}\text { Healthcare Utilization } \\
\text { and Costs }\end{array}$ & Quality of Life & $\begin{array}{l}\text { Pulmonary } \\
\text { Physiology }\end{array}$ & Symptoms & Adverse Events \\
\hline & & & $\begin{array}{l}\text { Emergency } \\
\text { department visits: } \\
\text { Year 1: } \\
\text { BT: } 4.4 \% \\
\text { Control: } 0 \% \\
\text { BT vs. control: } p=0.54 \\
\text { Year 2: } \\
\text { BT: } 6.7 \% \\
\text { Control:12.5\% } \\
\text { BT vs. control: } p=0.41 \\
\text { Year 3: } \\
\text { BT: } 4.7 \% \\
\text { Control: } 4.8 \% \\
\text { BT vs. control: } p=1.00\end{array}$ & & & & & $\begin{array}{l}22.2 \%, 24.4 \%, 18.6 \%, \\
18.6 \%, 9.5 \% \\
\text { Control years 1-3: } \\
8.3 \%, 16.7 \%, 19.1 \% \\
\text { Productive cough } \\
\text { BT year 1-5: } \\
20.0 \%, 4.4 \%, 4.7 \%, 0 \% \text {, } \\
2.4 \% \\
\text { Control years 1-3: } \\
20.8 \%, 4.2 \%, 0 \% \\
\text { Chest discomfort } \\
\text { BT years 1-5: } \\
17.8 \%, 4.4 \%, 7.0 \%, 2.3 \\
\%, 4.8 \% \\
\text { Control years 1-3: } \\
12.5 \%, 8.3 \%, 4.8 \% \\
\text { Nasopharyngitis } \\
\text { BT years 1-5: } \\
13.3 \%, 2.2 \%, 0 \%, 2.3 \%, \\
2.4 \% \\
\text { Control years 1-3: } \\
0 \%, 0 \%, 0 \% \\
\text { Nocturnal dyspnea } \\
\text { BT years 1-5: } \\
13.3 \%, 0 \%, 0 \%, 0 \%, 0 \% \\
\text { Control years 1-3: } \\
8.3 \%, 0 \%, 0 \% \\
\text { Respiratory tract } \\
\text { infection } \\
\text { BT years 1-5: } \\
11.1 \%, 6.7 \%, 11.6 \%, \\
11.6 \%, 9.5 \% \\
\text { Control years 1-3: } \\
\text { 20.8\%, 8.3\%, 4.8\% } \\
\text { Pharyngolaryngeal pain } \\
\text { BT years 1-5: } \\
11.1 \%, 0 \%, 0 \%, 0 \%, 0 \% \\
\text { Control years 1-3: } \\
12.5 \%, 0 \%, 0 \% \\
\text { Respiratory Tract } \\
\text { congestion }\end{array}$ \\
\hline
\end{tabular}




\begin{tabular}{|c|c|c|c|c|c|c|c|c|}
\hline Reference & $\begin{array}{c}\text { Attrition } \\
\mathrm{N}, \%\end{array}$ & $\begin{array}{l}\text { Asthma } \\
\text { Control }\end{array}$ & Exacerbations & $\begin{array}{l}\text { Healthcare Utilization } \\
\text { and Costs }\end{array}$ & Quality of Life & $\begin{array}{l}\text { Pulmonary } \\
\text { Physiology }\end{array}$ & Symptoms & Adverse Events \\
\hline & & & & & & & & 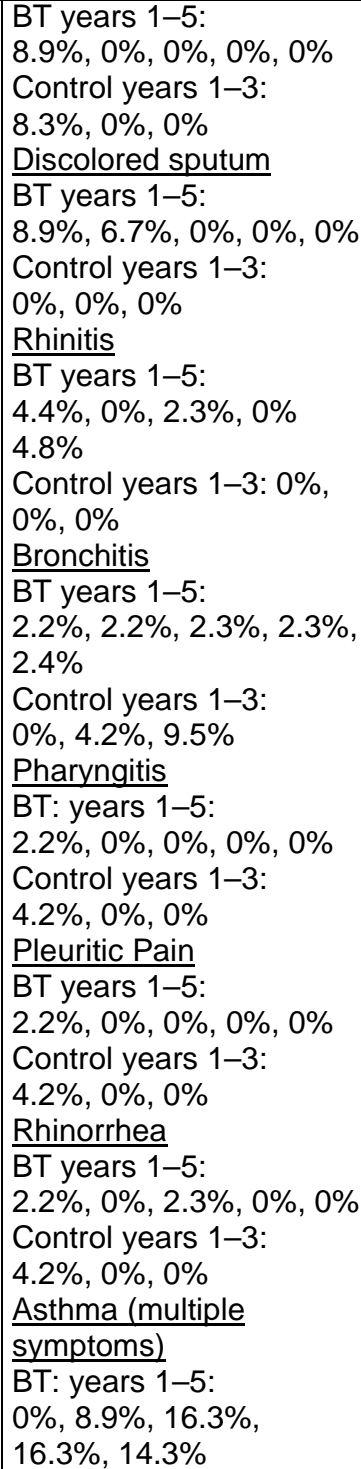 \\
\hline
\end{tabular}




\begin{tabular}{|c|c|c|c|c|c|c|c|c|}
\hline Reference & $\begin{array}{l}\text { Attrition } \\
\mathrm{N}, \%\end{array}$ & $\begin{array}{l}\text { Asthma } \\
\text { Control }\end{array}$ & Exacerbations & $\begin{array}{l}\text { Healthcare Utilization } \\
\text { and Costs }\end{array}$ & Quality of Life & $\begin{array}{l}\text { Pulmonary } \\
\text { Physiology }\end{array}$ & Symptoms & Adverse Events \\
\hline & & & & & & & & $\begin{array}{l}\text { Control years 1-3: } \\
\text { 0\%, 8.3\%, 4.8\% } \\
\text { Sinusitis } \\
\text { BT years 1-5: } \\
0 \%, 2.2 \%, 4.7 \%, 4.7 \% \text {, } \\
4.8 \% \\
\text { Control years 1-3: } \\
0 \%, 4.2 \%, 0 \% \\
\text { Nasal polyps } \\
\text { BT years 1-5: } \\
\text { 0\%, 2.2\%, 0\%, 4.7\%, 0\% } \\
\text { Control years 1-3: 0\%, } \\
\text { 0\%, 0\% } \\
\text { Pneumonia } \\
\text { BT years 1-5: } \\
0 \%, 0 \%, 2.3 \%, 0 \%, 0 \% \\
\text { Control years 1-3: } 0 \% \\
0 \%, 4.8 \%\end{array}$ \\
\hline
\end{tabular}




\begin{tabular}{|c|c|c|c|c|c|c|c|c|}
\hline Reference & $\begin{array}{l}\text { Attrition } \\
\mathrm{N}, \%\end{array}$ & $\begin{array}{l}\text { Asthma } \\
\text { Control }\end{array}$ & Exacerbations & $\begin{array}{l}\text { Healthcare Utilization } \\
\text { and Costs }\end{array}$ & Quality of Life & $\begin{array}{l}\text { Pulmonary } \\
\text { Physiology }\end{array}$ & Symptoms & Adverse Events \\
\hline & & & $\begin{array}{l}\text { BT: } 1.02 \text { (53.6\% of } \\
\text { patients) } \\
\text { Sham: } 0.91 \text { (45.9\% of } \\
\text { patients) } \\
\text { PPS sham >BT: } \\
25.8 \% \\
\text { ED visits for } \\
\text { respiratory } \\
\text { symptoms per } \\
\text { patient over } 12 \\
\text { months: } \\
\text { BT: } 0.13 \text { (8.4\% of } \\
\text { subjects) } \\
\text { Sham: } 0.45 \text { (15.3\% of } \\
\text { subjects) } \\
\text { PPS >BT: } 99.7 \% \\
\text { Number of } \\
\text { respiratory-related } \\
\text { hospitalizations per } \\
\text { subject: } \\
\text { BT: } 0.13 \text { (10.5\% of } \\
\text { subjects) } \\
\text { Sham: } 0.14 \text { (5.1\% of } \\
\text { subjects) } \\
\text { PPS sham >BT: } \\
57.2 \% \\
\text { Risk reduction in ED } \\
\text { visits for respiratory } \\
\text { symptoms BT vs. } \\
\text { sham: } \\
\text { 0.07 vs. 0.43 } \\
\text { visits/subject/year } \\
84 \% \text { reduction } \\
\text { PPS: } 99.9 \%\end{array}$ & $\begin{array}{l}\text { Days lost from } \\
\text { work/school/other } \\
\text { activities due to } \\
\text { asthma at } 12 \text { months: } \\
\text { BT: } 1.315(0.361) \\
\text { Sham: } 3.915(1.553) \\
\text { BT vs. sham: } \\
\text { PPS: } 99.3 \%\end{array}$ & & $\begin{array}{l}\text { PPS: } 80.6 \% \\
\text { Airway } \\
\text { responsiveness, } \\
\text { PC20 } \\
\text { defined by a } \\
\text { provocative } \\
\text { concentration of } \\
\text { methacholine required } \\
\text { to lower the FEV1 by } \\
20 \% \text { (PC20) of less } \\
\text { than } 8 \text { mg per milliliter, } \\
\text { BT baseline: geometric } \\
\text { mean ( } 95 \% \text { C.I.) PC20 } \\
0.24(0.15,0.4) \\
\text { BT } 12 \text { months: } \\
0.61(0.36,1.03) \text { mg/ml, } \\
\text { or } 1.31 \pm 2.39 \text { doubling } \\
\text { concentrations over } \\
\text { baseline } \\
\text { Control baseline: } \\
0.32(0.20,0.51) \\
\text { Control } 12 \text { months: } \\
0.5(0.31,0.80 \text { ) mg/ml, } \\
\text { or } 0.66 \pm 2.69 \text { doublings } \\
\text { “The differences over } \\
\text { baseline between } \\
\text { groups did not reach } \\
\text { statistical significance } \\
\text { at any time point } \\
\text { (P=0.06, } 0.18 \text { and } \\
0.17 \text { for } 3,6 \text { and } 12 \\
\text { months respectively)" } \\
\text { (data supplement) }\end{array}$ & $\begin{array}{l}\text { Sham } \\
\text { baseline: } 3.9 \\
(2.53) \\
\text { Sham } 12 \\
\text { months: } \\
2.3(2.17) \\
\text { BT vs. sham: } \\
\text { PPS: } 63.7 \%\end{array}$ & $\begin{array}{l}\text { During the treatment } \\
\text { period } \\
\text { BT: } 16 \text { people (8.4\%) } \\
\text { required } 19 \\
\text { hospitalizations } \\
\text { (10 occurred on the day } \\
\text { of the procedure) for } \\
\text { respiratory symptoms } \\
\text { (worsening of asthma, } \\
12 \text { in } 10 \text { subjects; } \\
\text { segmental atelectasis, } \\
3 \text { in } 2 \text { subjects; lower } \\
\text { respiratory tract infection, } \\
1 \text { subject; low FEV } 1 \text {, } \\
1 \text { subject; hemoptysis, } \\
1 \text { subject; and aspirated } \\
\text { prosthetic tooth; one } \\
\text { subject) } \\
\text { Sham: Two patients } \\
\text { (2.0\%) required two } \\
\text { hospitalizations (both } \\
\text { worsening of asthma) } \\
\text { During the post treatment } \\
\text { period } \\
\text { BT: } 70 \% \text { reported } \\
\text { respiratory AEs } \\
\text { Sham: } 80 \% \text { reported } \\
\text { respiratory AEs } \\
\text { Proportion of people } \\
\text { reporting worsening of } \\
\text { asthma: } \\
\text { BT: } 27.3 \text {; Sham: } 42.9 \% \\
\text { BT vs. sham: } \\
\text { PPS: } 99.7 \% \\
\text { Rate of upper and } \\
\text { lower respiratory tract } \\
\text { infections requiring } \\
\text { antibiotics (SD): } \\
\text { BT: } 0.007 \text { (0.014) events/ } \\
\text { subject/week (24.1\% of } \\
\text { patients) }\end{array}$ \\
\hline
\end{tabular}




\begin{tabular}{|c|c|c|c|c|c|c|c|c|}
\hline Reference & $\begin{array}{l}\text { Attrition } \\
\mathrm{N}, \%\end{array}$ & $\begin{array}{l}\text { Asthma } \\
\text { Control }\end{array}$ & Exacerbations & $\begin{array}{l}\text { Healthcare Utilization } \\
\text { and Costs }\end{array}$ & Quality of Life & $\begin{array}{l}\text { Pulmonary } \\
\text { Physiology }\end{array}$ & Symptoms & Adverse Events \\
\hline & & & & & & & & $\begin{array}{l}\text { Sham: } 0.006(0.012) \\
\text { events/subject/week } \\
\text { (24.5\% of patients) }\end{array}$ \\
\hline $\begin{array}{l}\text { Cox } 2007^{3} \\
\text { AIR Study }\end{array}$ & $\begin{array}{l}\mathrm{BT}: \mathrm{N}=56 \\
\text { at baseline } \\
7 \% \text { attrition } \\
\text { at } 12 \\
\text { months } \\
\text { Control: } \\
\mathrm{N}=56 \text { at } \\
\text { baseline } \\
12.5 \% \\
\text { attrition at } \\
12 \text { months }\end{array}$ & $\begin{array}{l}\text { ACQ score: } \\
\text { BT baseline: } \\
2.50 \text { (0.92) } \\
\text { BT 12 } \\
\text { months: } 1.32 \\
\text { (0.85) } \\
\text { Control } \\
\text { baseline: } 2.16 \\
(0.86) \\
\text { Control } 12 \\
\text { months: } 1.69 \\
\text { (0.99) } \\
\text { BT vs control: } \\
\text { p=0.001 } \\
\text { SMD=-0.402 } \\
\text { SE=0.201 } \\
\text { Patients } \\
\text { taking high } \\
\text { dose ICS } \\
\text { (post-hoc } \\
\text { analysis } \\
n=32 ; 16 \text { BT, } \\
\text { 16 Control) } \\
\text { who } \\
\text { required } \\
>1,000 \mu \text { g } \\
\text { BDP or } \\
\text { equivalent at } \\
\text { baseline: } \\
\text { ACQ } \\
\text { BT: } 2.88 \\
\text { (0.63) to } 1.34 \\
\text { (0.95) } \\
\text { Control: } 2.20 \\
\text { (0.67) to } 1.99 \\
\text { (1.02) }\end{array}$ & $\begin{array}{l}\text { Severe } \\
\text { exacerbations per } \\
\text { patient per week in } \\
\text { past } 12 \text { months } \\
\text { (Mean } \pm \text { SD) BT vs. } \\
\text { Control: } \\
\text { BT baseline: } \\
0.07 \pm 0.18 \\
\text { BT } 12 \text { months: } \\
0.01 \pm 0.08 \\
\text { Control baseline: } \\
0.09 \pm 0.31 \\
\text { Control } 12 \text { months: } \\
0.06 \pm 0.24 \\
\text { Difference between } \\
\text { the two groups in the } \\
\text { change from baseline } \\
\text { at } 12 \text { months }=n . s . \\
\text { Exacerbations } \\
\text { during the } 2-\text { week } \\
\text { periods at } 3,6, \text { and } \\
12 \text { months when } \\
\text { patients were } \\
\text { treated with ICs } \\
\text { alone compared with } \\
\text { baseline: } \\
\text { BT: }-0.16 \pm 0.37 \\
\text { Control: } 0.04 \pm 0.29 \\
\text { BT vs. control: } \\
\text { p=0.005 } \\
\text { Analysis with } \\
\text { Wilcoxon rank-sum } \\
\text { method (p=0.01 } \\
\text { between the groups) } \\
\text { Mild exacerbations } \\
\text { per patients per } \\
\text { week in past } \\
12 \text { months (Mean } \\
\pm S D \text { ) BT vs. control: }\end{array}$ & $\begin{array}{l}\text { Rescue medication } \\
\text { use (puffs per week) } \\
\text { BT baseline: } 19.8(17.2) \\
\text { BT } 12 \text { months: } 10.9 \\
(15.0) \\
\text { Control baseline: } 16.0 \\
(18.8) \\
\text { Control } 12 \text { months: } 14.8 \\
(21.2) \\
p=0.04\end{array}$ & 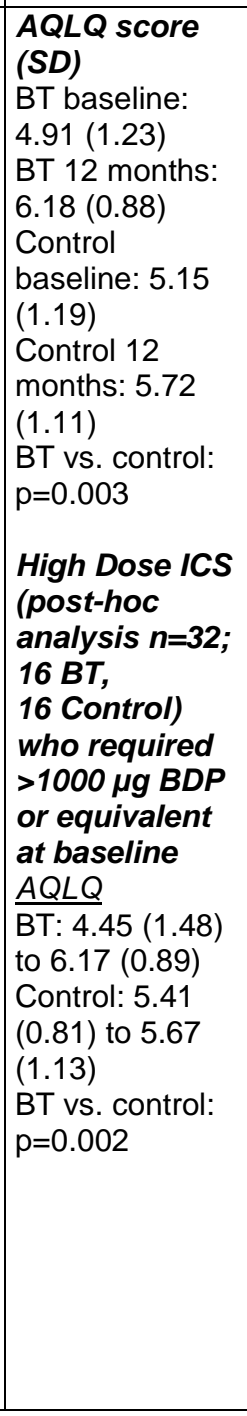 & $\begin{array}{l}\text { Morning PEF, L/min } \\
\text { (SD): } \\
\text { BT baseline: } 349.3 \\
\text { (90.6) } \\
\text { BT 12 months: } 388.6 \\
\text { (105.0) } \\
\text { Control baseline: } 372.4 \\
\text { (99.9) } \\
\text { Control } 12 \text { months: } \\
\text { 380.9 (92.9) } \\
\text { BT vs. control: } p=0.003 \\
\text { Evening PEF: } \\
\text { BT baseline: } 359.7 \\
\text { (88.4) } \\
\text { BT 12 months: } 397.4 \\
(102.8) \\
\text { Control baseline: } 379.1 \\
\text { (98.7) } \\
\text { Control 12 months: } \\
\text { 389.0 (93.9) } \\
\text { BT vs. control: } p=0.006 \\
\text { Pre-bronchodilator } \\
\text { FEV1 \% predicted } \\
\text { (SD), baseline and } 12 \\
\text { months: } \\
\text { BT baseline: } 70.4 \\
\text { (12.1) } \\
\text { BT 12 months: } 75.2 \\
\text { (13.9) } \\
\text { Control baseline: } 70.7 \\
\text { (10.5) } \\
\text { Control 12 months: } \\
\text { 72.4 (12.6) } \\
\text { BT vs. control: not } \\
\text { significant } \\
\text { Airway hyper- } \\
\text { responsivenessPC } 20 \\
\text { geometric mean, } \\
\text { mg/ml (95\% Cl): } \\
\end{array}$ & $\begin{array}{l}\text { Symptom- } \\
\text { free days: } \\
\text { BT baseline: } \\
24.7 \text { (30.5) } \\
\text { BT 12 } \\
\text { months: } 65.4 \\
\text { (40.4) } \\
\text { Control } \\
\text { baseline: } 32.3 \\
\text { (34.3) Control } \\
12 \text { months: } \\
49.4 \text { (41.3) } \\
\text { BT vs. } \\
\text { control: } \\
\text { p=0.005 } \\
\text { Study } \\
\text { extrapolated } \\
\text { that BT group } \\
\text { might gain } \\
148 \\
\text { symptom-free } \\
\text { days per year } \\
\text { compared } \\
\text { with 62 for } \\
\text { control group } \\
\text { Total } \\
\text { symptom } \\
\text { score: } \\
\text { BT baseline: } \\
\text { 3.16 (2.21) } \\
\text { BT 12 } \\
\text { months: } 1.25 \\
\text { (1.97) } \\
\text { Control } \\
\text { baseline: } 2.65 \\
\text { (2.55) Control } \\
\text { 12 months: } \\
2.00 \text { (2.23) }\end{array}$ & $\begin{array}{l}\text { Treatment period plus } \\
6 \text { week } \\
\text { AE frequency } \\
\text { (\% patients with AE) } \\
\text { Dyspnea } \\
\text { BT: } 70.9 \%, \\
\text { Control: } 33.3 \% \\
\text { BT vs. control: } p<0.001 \\
\text { Wheezing } \\
\text { BT: } 61.8 \%, \\
\text { Control: } 13.0 \% \\
\text { BT vs. control: } p<0.001 \\
\text { Cough } \\
\text { BT: } 52.7 \% . \\
\text { Control: } 18.5 \% \\
\text { BT vs. control: } p<0.001 \\
\text { Chest discomfort } \\
\text { BT: } 47.3 \%, \\
\text { Control: } 20.4 \% \\
\text { BT vs. control: } p=0.004 \\
\text { Night awakenings } \\
\text { BT: } 40.0 \%, \text { Control: } 9.3 \% \\
\text { BT vs. control: } p<0.001 \\
\text { Productive cough } \\
\text { BT: } 40.0 \%, \\
\text { Control: } 11.1 \% \\
\text { BT vs. control: } p<0.001 \\
\text { Upper respiratory tract } \\
\text { infection BT: } 12.7 \%, \\
\text { Control: } 3.7 \% \\
\text { BT vs. control: } p=0.16 \\
\text { Bronchial irritation } \\
\text { BT: } 9.1 \%, \text { Control: } 0 \% \\
\text { BT vs. control: } p=0.06 \\
\text { Nasal congestion } \\
\text { BT: } 12.7 \%, \\
\text { Control: } 11.1 \% \\
\text { BT vs. control: } p=1.00 \\
\text { Sputum discolored } \\
\end{array}$ \\
\hline
\end{tabular}




\begin{tabular}{|c|c|c|c|c|c|c|c|c|}
\hline Reference & $\begin{array}{l}\text { Attrition } \\
\mathrm{N}, \%\end{array}$ & $\begin{array}{l}\text { Asthma } \\
\text { Control }\end{array}$ & Exacerbations & $\begin{array}{l}\text { Healthcare Utilization } \\
\text { and Costs }\end{array}$ & Quality of Life & $\begin{array}{l}\text { Pulmonary } \\
\text { Physiology }\end{array}$ & Symptoms & Adverse Events \\
\hline & & $\begin{array}{l}\text { BT vs. } \\
\text { control: } \\
p=0.004\end{array}$ & $\begin{array}{l}\text { BT baseline: } \\
0.35 \pm 0.32 \\
\text { BT } 12 \text { months: } \\
0.18 \pm 0.31 \\
\text { Control baseline: } \\
0.28 \pm 0.31 \\
\text { Control } 12 \text { months: } \\
0.31 \pm 0.46 \\
\text { Difference between } \\
\text { the two groups in the } \\
\text { change from baseline } \\
\text { at } 12 \text { months: } p=0.03\end{array}$ & & & $\begin{array}{l}\text { BT baseline: } 0.24 \\
\text { (0.15-0.4) } \\
\text { BT 12 months: } 0.61 \\
\text { (0.36-1.03) } \\
1.31 \text { (2.39) doubling } \\
\text { concentrations over } \\
\text { baseline } \\
\text { Control baseline: } 0.32 \\
\text { (0.20-0.51) } \\
\text { Control } 12 \text { months: } 0.5 \\
(0.31-0.80) \\
0.66 \text { (2.69) doublings } \\
\text { p=0.17 } \\
\text { Patients taking high } \\
\text { dose ICS (post-hoc } \\
\text { analysis } n=32 ; 16 \text { BT, } \\
16 \text { Control) who } \\
\text { required >1000 } \mu g \\
\text { BDP or equivalent at } \\
\text { baseline: } \\
\text { Morning PEF } \\
\text { BT baseline: } 378.2 \\
\text { (69.8) } \\
\text { BT 12 months: } 441.8 \\
\text { (103.9) } \\
\text { Control baseline: } 321.9 \\
\text { (65.9) } \\
\text { Control } 12 \text { months: } \\
346.2 \text { (66.4) } \\
\text { BT vs. control: } p=0.05 \\
\text { Airway hyper- } \\
\text { responsiveness } \\
\text { BT baseline: } 0.33 \\
\text { (0.11-0.97) } \\
\text { BT 12 months: } \\
1.71 \text { (0.65-4.49) } \\
2.39 \text { (SD } 2.78) \\
\text { doublings from } \\
\text { baseline } \\
\text { Control baseline: } 0.45 \\
\text { (0.19-1.03) }\end{array}$ & $\begin{array}{l}\text { BT vs. } \\
\text { control: } \\
p=0.01 \\
\\
S M D=-0.617 \\
S E=0.204\end{array}$ & $\begin{array}{l}\text { BT: } 10.9 \%, \text { Control: } 0 \% \\
\text { BT vs. control: } p=0.03 \\
\text { Dry mouth } \\
\text { BT: } 3.6 \%, \text { Control: } 0 \% \\
\text { BT vs. control: } p=0.50 \\
\text { Abnormal chest sound } \\
\text { BT: } 5.5 \%, \text { Control: } 0 \% \\
\text { BT vs. control: } p=0.24 \\
\text { Bronchospasm } \\
\text { BT: } 7.3 \%, \text { Control: } 0 \% \\
\text { BT vs. control: } p=0.12 \\
\text { Post-treatment period } \\
\text { (6 weeks-12 months) } \\
\text { Dyspnea } \\
\text { BT: } 49.1 \%, \text { Control: } \\
\text { 53.8\% } \\
\text { BT vs. control: } p=0.70 \\
\text { Cough } \\
\text { BT: } 38.2 \%, \text { Control: } \\
\text { 36.5\% } \\
\text { BT vs. control: } p=1.00 \\
\text { Nasal congestion } \\
\text { BT: } 27.3 \%, \text { Control: } \\
\text { 26.9\% } \\
\text { BT vs. control: } p=1.00 \\
\text { Wheezing } \\
\text { BT: } 29.1 \%, \text { Control: } \\
\text { 23.1\% } \\
\text { BT vs. control: } p=0.52 \\
\text { Productive cough } \\
\text { BT: } 23.6 \%, \text { Control: } \\
\text { 23.1\% } \\
\text { BT vs. control: } p=1.00 \\
\text { Chest discomfort } \\
\text { BT: } 21.8 \%, \text { Control: } \\
\text { 13.5\% } \\
\text { BT vs. control: } p=0.32 \\
\text { Upper respiratory tract } \\
\text { infection BT: } 18.2 \%, \\
\text { Control: } 5.8 \% \\
\text { BT vs. control: } p=0.07\end{array}$ \\
\hline
\end{tabular}




\begin{tabular}{|c|c|c|c|c|c|c|c|c|}
\hline Reference & $\begin{array}{l}\text { Attrition } \\
\mathrm{N}, \%\end{array}$ & $\begin{array}{l}\text { Asthma } \\
\text { Control }\end{array}$ & Exacerbations & $\begin{array}{l}\text { Healthcare Utilization } \\
\text { and Costs }\end{array}$ & Quality of Life & $\begin{array}{l}\text { Pulmonary } \\
\text { Physiology }\end{array}$ & Symptoms & Adverse Events \\
\hline & & & & & & $\begin{array}{l}\text { Control } 12 \text { months: } \\
0.30(0.09-1.01) \\
-0.57 \text { (SD 3.04) } \\
\text { doublings from } \\
\text { baseline } \\
\text { BT vs. control: } p=0.03\end{array}$ & & $\begin{array}{l}\text { Night awakenings } \\
\text { BT: } 12.7 \%, \text { Control: } 9.6 \% \\
\text { BT vs. control: } p=0.76 \\
\text { Pharyngolaryngeal pain } \\
\text { BT: } 10.9 \% \text {, Control: } \\
\text { 13.5\% } \\
\text { BT vs. control: } p=0.77 \\
\text { Nasopharyngitis } \\
\text { BT: } 10.9 \% \text { vs, Control: } \\
5.8 \% \\
\text { BT vs. control: } p=0.49 \\
\text { Respiratory tract } \\
\text { congestion } \\
\text { BT: } 9.1 \%, \text { Control: } 3.8 \% \\
\text { BT vs. control: } p=0.44 \\
\text { Respiratory tract } \\
\text { infection } \\
\text { BT: } 9.1 \%, \text { Control: } 17.3 \% \\
\text { BT vs. control: } p=0.26 \\
\text { Bronchitis } \\
\text { BT: } 1.8 \%, \text { Control: } 0 \% \\
\text { BT vs. control: } p=1.00 \\
\text { Throat irritation } \\
\text { BT: } 3.6 \%, \text { Control: } 3.8 \% \\
\text { BT vs. control: } p=1.00\end{array}$ \\
\hline $\begin{array}{l}\text { Pavord } 2007^{2} \\
\text { RISA Study }\end{array}$ & $\begin{array}{l}\text { BT: } 17 \\
\text { patients } \\
\text { assigned, } \\
2 \text { withdrew } \\
\text { prior to BT; } \\
11 \% \\
\text { attrition by } \\
52 \text { weeks } \\
\text { Control: } 17 \\
\text { assigned; } \\
0 \% \text { attrition }\end{array}$ & $\begin{array}{l}\text { ACQ score } \\
\text { change: } \\
\text { BT: -0.99 } \\
\text { (0.83) } \\
\text { Control: }-0.22 \\
\text { (0.78) } \\
\text { BT vs. } \\
\text { control: } \\
\text { p=0.01 } \\
\text { SMD }=-0.958 \\
\text { SE }=0.374\end{array}$ & $\begin{array}{l}\text { Number of patients } \\
\text { able to wean off } \\
\text { OCS (through week } \\
\text { 52): } \\
\text { BT: } 4 \text { of } 8 \text { patients } \\
\text { Control: } 1 \text { of } 7 \\
\text { patients } \\
\text { BT vs. control: } p=0.28 \\
\text { Mean reduction in } \\
\text { OCS dose: } \\
\text { BT: } 63.5(45.4) \% \\
\text { Control: } 26.2(40.7) \% \\
\text { BT vs. control: } p=0.12 \\
\text { Treatment period } \\
\text { hospitalizations for } \\
\text { respiratory adverse } \\
\text { events: }\end{array}$ & $\begin{array}{l}\text { Overall reduction in } \\
\text { ICS dose } \\
\text { BT: } 28.6(30.4) \% \\
\text { Control: } 20.0(32.9) \% \\
\text { (p=0.59) } \\
\text { Reduction in short- } \\
\text { acting b2-agonist use } \\
\text { at } 52 \text { weeks, } \\
\text { puffs/week: } \\
\text { BT: -25.6 (31.2) } \\
\text { Control: -6.1 (12.4) } \\
\text { BT vs. control: p<0.05 } \\
\text { Rescue medication } \\
\text { use at } 22 \text { weeks } \\
\text { (puffs/week) } \\
\text { BT: -26.6 (40.1) } \\
\text { Control: }-1.5(11.7)\end{array}$ & \begin{tabular}{|l} 
AQLQ score \\
(change from \\
baseline to \\
$\mathbf{1 2}$ months) \\
BT: $1.53(0.79)$ \\
Control: 0.42 \\
(0.82) \\
BT vs. control: \\
p $=0.001$
\end{tabular} & $\begin{array}{l}\text { Mean \% change in } \\
\text { pre-bronchodilator } \\
\text { FEV1 (\% predicted) } \\
\text { BT: } 7.97 \%, \text { SD } 19.13 \% \\
\text { Control group: } 1.89 \%, \\
\text { SD } 15.00 \% \\
(p=0.322)\end{array}$ & NR & $\begin{array}{l}\text { Respiratory AEs during } \\
\text { treatment period } \\
\text { Wheezing } \\
\text { BT: } 17.6 \% \text {, Control: } 7.0 \% \\
\text { BT vs. control: } p=0.072 \\
\text { Cough } \\
\text { BT: } 16.9 \%, \\
\text { Control: } 17.5 \% \\
\text { BT vs. control: } p=1.000 \\
\text { Chest discomfort } \\
\text { BT: } 15.4 \%, \text { Control: } 5.3 \% \\
\text { BT vs. control: } p=0.057 \\
\text { Dyspnea } \\
\text { BT: } 15.4 \%, \\
\text { Control: } 15.8 \% \\
\text { BT vs. control: } p=1.000\end{array}$ \\
\hline
\end{tabular}




\begin{tabular}{|c|c|c|c|c|c|c|c|c|}
\hline Reference & $\begin{array}{l}\text { Attrition } \\
\mathrm{N}, \%\end{array}$ & $\begin{array}{l}\text { Asthma } \\
\text { Control }\end{array}$ & Exacerbations & $\begin{array}{l}\text { Healthcare Utilization } \\
\text { and Costs }\end{array}$ & Quality of Life & $\begin{array}{l}\text { Pulmonary } \\
\text { Physiology }\end{array}$ & Symptoms & Adverse Events \\
\hline & & & $\begin{array}{l}\text { BT: } 7 \text { in } 4 \text { patients } \\
\text { Events were due to } \\
\text { asthma exacerbations } \\
\text { and two events } \\
\text { included partial } \\
\text { collapse of a lower } \\
\text { lobe of the lung } 1 \text { and } \\
2 \text { days after BT, } \\
\text { respectively } \\
\text { Control: No } \\
\text { hospitalizations } \\
\text { Median length of stay } \\
\text { per hospitalization: } \\
2 \text { days } \\
\text { Post-treatment } \\
\text { period } \\
\text { hospitalizations: } \\
\text { BT: } 5 \text { occurred in } \\
3 \text { patients } \\
\text { Control: } 4 \text { in } 1 \text { patient } \\
\text { BT vs. control: } p=0.32 \\
\text { Exacerbations: } \\
\text { Control: } 1 \text { patient on } \\
\text { Day } 42 \text { ICU } \\
\text { (respiratory failure) }\end{array}$ & BT vs. control: $p=0.05$ & & & & 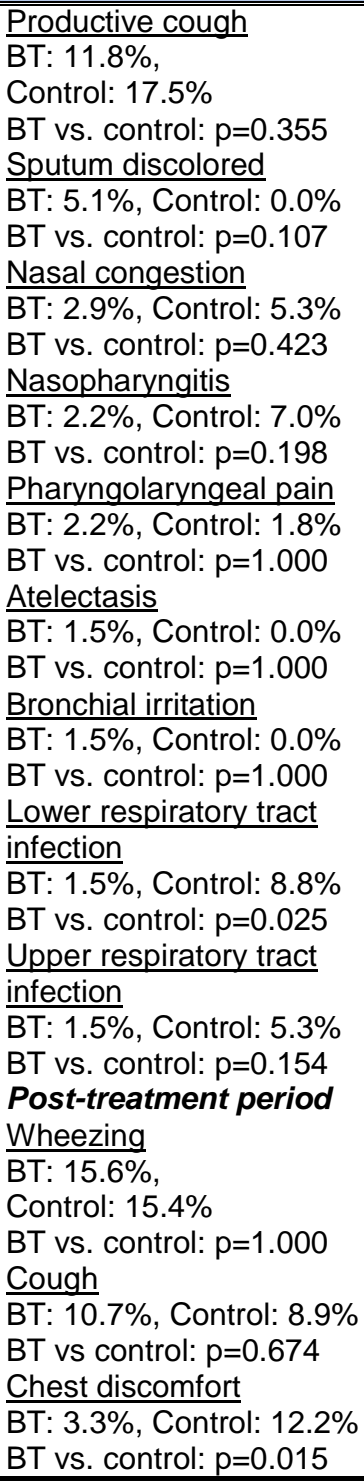 \\
\hline
\end{tabular}




\begin{tabular}{|c|c|c|c|c|c|c|c|c|}
\hline Reference & $\begin{array}{l}\text { Attrition } \\
\mathrm{N}, \%\end{array}$ & $\begin{array}{l}\text { Asthma } \\
\text { Control }\end{array}$ & Exacerbations & $\begin{array}{l}\text { Healthcare Utilization } \\
\text { and Costs }\end{array}$ & Quality of Life & $\begin{array}{l}\text { Pulmonary } \\
\text { Physiology }\end{array}$ & Symptoms & Adverse Events \\
\hline & & & & & & & & 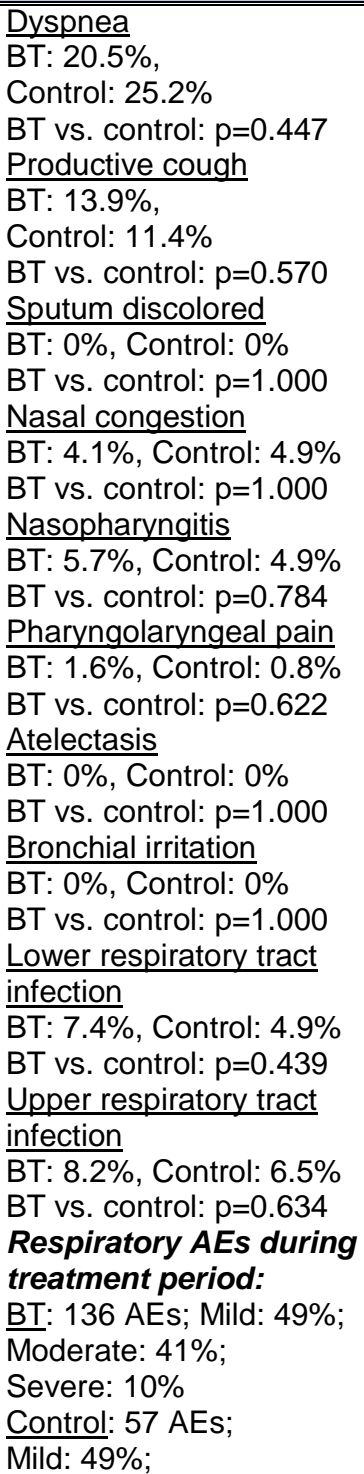 \\
\hline
\end{tabular}




\begin{tabular}{|c|c|c|c|c|c|c|c|c|}
\hline Reference & $\begin{array}{l}\text { Attrition } \\
\mathrm{N}, \%\end{array}$ & $\begin{array}{l}\text { Asthma } \\
\text { Control }\end{array}$ & Exacerbations & $\begin{array}{l}\text { Healthcare Utilization } \\
\text { and Costs }\end{array}$ & Quality of Life & $\begin{array}{l}\text { Pulmonary } \\
\text { Physiology }\end{array}$ & Symptoms & Adverse Events \\
\hline & & & & & & & & $\begin{array}{l}\text { Moderate: 47\%; } \\
\text { Severe: } 4 \% \\
\text { Treatment period } \\
\text { severe respiratory AEs } \\
\text { BT: } 2 \text { people had } 5 \\
\text { events (chest infection, } \\
\text { increased wheeze, } \\
\text { cough, and shortness of } \\
\text { breath on exertion) } \\
\text { Control: } 2 \text { patients } \\
\text { (dyspnea, chest } \\
\text { infection) that did not } \\
\text { require hospitalization } \\
\text { Post-treatment period } \\
\text { severe respiratory AEs } \\
\text { BT: } 2 \text { patients had } 5 \\
\text { severe respiratory AEs } \\
\text { (increased wheeze, } \\
\text { chest tightness, } \\
\text { increased } \\
\text { breathlessness, } \\
\text { nocturnal wheeze, and } \\
\text { chest infection) } \\
\text { Control: } 1 \text { patient had } \\
\text { one severe respiratory } \\
\text { AE (flu-like syndrome) }\end{array}$ \\
\hline
\end{tabular}

ACQ=Asthma Control Questionnaire; ACQ7=Asthma Control Questionnaire 7; AE=adverse event; AQLQ=Asthma Quality of Life Questionnaire; scores range from 1 to 7; BDP= beclomethasone dipropionate equivalent doses; $\mathrm{BT}=$ bronchial thermoplasty; $\mathrm{CT}=$ computed tomography; $\mathrm{ED}=$ =emergency department; $\mathrm{FEV}=$ =forced expiratory volume; ICS=inhaled corticosteroid; ICU=intensive care unit; ITT-intention-to-treat analysis; $\mathrm{LABA}=$ long acting beta-agonist; $\mathrm{MID}=$ minimal clinical important difference; $\mathrm{NR}=$ not reported; OCS=oral corticosteroid; $\mathrm{PC} 20=$ provocative concentration of methacholine causing a 20\% drop in FEV1; PEF=peak expiratory flow; PPS=posterior probability of superiority; RCT=randomized clinical trial; SD=standard deviation; SE=standard error; $\mathrm{SMD}=$ standardized mean difference: Calculated by ECRI Institute 
Table C-3. Risk of bias assessment for included RCTs

\begin{tabular}{|c|c|c|c|c|c|c|c|c|}
\hline Study & $\begin{array}{l}\text { Sequence } \\
\text { Generation }\end{array}$ & $\begin{array}{c}\text { Allocation } \\
\text { Concealment }\end{array}$ & $\begin{array}{c}\text { Blinding of Participants, } \\
\text { Personnel and Outcome } \\
\text { Assessors } \\
\end{array}$ & $\begin{array}{c}\text { Incomplete } \\
\text { Outcome Data }\end{array}$ & $\begin{array}{l}\text { Selective } \\
\text { Outcome } \\
\text { Reporting } \\
\end{array}$ & $\begin{array}{c}\text { Other } \\
\begin{array}{c}\text { Sources of } \\
\text { Bias }\end{array} \\
\end{array}$ & $\begin{array}{c}\text { Overall Risk } \\
\text { of Bias }\end{array}$ & Comments \\
\hline $\begin{array}{l}\text { Castro et al. } \\
2010^{1} \\
\text { AIR } 2 \text { Study }\end{array}$ & Low & Unclear & Low & Low & Low & High & Medium & $\begin{array}{l}\text { Study was randomized, double-blind, } \\
\text { sham-controlled trial; patients and outcome } \\
\text { assessors blinded; intent-to-treat analysis } \\
\text { used; allocation method described but } \\
\text { concealment not explicit; study funded by } \\
\text { BT device manufacturer }\end{array}$ \\
\hline $\begin{array}{l}\text { Cox et al. } \\
2007^{3} \\
\text { AIR Study }\end{array}$ & Low & Low & High & Low & Low & High & High & $\begin{array}{l}\text { Unblinded study; intent-to-treat analysis } \\
\text { used; study funded by BT device } \\
\text { manufacturer }\end{array}$ \\
\hline $\begin{array}{l}\text { Pavord et al. } \\
2007^{2} \\
\text { RISA Study }\end{array}$ & Low & Low & High & Low & Low & High & High & $\begin{array}{l}\text { Unblinded study; full followup of all patients } \\
\text { who began trial; lack of clarity regarding } \\
\text { role of funding entity; study funded by BT } \\
\text { device manufacturer }\end{array}$ \\
\hline
\end{tabular}

AIR=Asthma Intervention Research Trial 2; BT=bronchial thermoplasty; RISA=Research in Severe Asthma Trial 
Table C-4. Strength of evidence assessments

\begin{tabular}{|c|c|c|c|c|c|c|c|c|c|}
\hline Comparison & Outcome $^{a}$ & Study Results & $\begin{array}{c}\text { Study } \\
\text { Design and } \\
\text { Sample Size }\end{array}$ & $\begin{array}{c}\text { Study } \\
\text { Limitations }^{b}\end{array}$ & Directness & Consistency & Precision & $\begin{array}{c}\text { Reporting } \\
\text { Bias }\end{array}$ & $\begin{array}{l}\text { Overall } \\
\text { Evidence } \\
\text { Strength }\end{array}$ \\
\hline \multirow[t]{2}{*}{$\begin{array}{l}\text { BT and } \\
\text { standard care } \\
\text { (medical } \\
\text { management) } \\
\text { vs. standard } \\
\text { care alone }\end{array}$} & Asthma control & $\begin{array}{l}\text { Favors BT, but clinical importance } \\
\text { unclear: ACQ scores (scale } 0 \text { to } 6 \text {; lower } \\
\text { scores indicate better control; MID=0.5) } \\
\text { improved in patients who underwent BT } \\
\text { compared to those who received standard } \\
\text { medical management } \\
\text { Calculated based on data reported in the } \\
\text { publications: } \\
\text { AIR: Mean difference in ACQ change } \\
\text { score:-0.71, } 95 \% \mathrm{Cl} \text { - } 1.05 \text { to }-0.37 \text { (at } 12 \\
\text { months after last BT treatment); upper } \\
\text { bound is less than MID } \\
\text { RISA: Mean difference in ACQ score } \\
\text { change }=-0.77,95 \% \text { Cl: }-1.33 \text { to }-0.21 \text { (at } \\
\text { week 52, which was } 46 \text { weeks after last BT } \\
\text { treatment); upper bound is less than MID }\end{array}$ & $\begin{array}{l}2 \mathrm{RCTs}^{2,3} \\
\mathrm{n}=144\end{array}$ & Medium $^{\mathrm{c}}$ & Direct & Consistent & $\begin{array}{l}\text { Imprecise; } \\
\text { lack of } \\
\text { precision } \\
\text { in } \\
\text { reporting } \\
\text { test } \\
\text { statistics; } \\
\text { MID not } \\
\text { met }\end{array}$ & $\begin{array}{l}\text { Not } \\
\text { detected }\end{array}$ & Low \\
\hline & $\begin{array}{l}\text { Exacerbations } \\
\text { Severe (after } \\
\text { treatment } \\
\text { period) }\end{array}$ & $\begin{array}{l}\text { Inconclusive: Rates of severe } \\
\text { exacerbations per patient per week did not } \\
\text { vary between treatment conditions. } \\
\text { Exacerbations were counted during } 2 \text { - } \\
\text { week periods at } 3,6 \text { and } 12 \text { months while } \\
\text { LABA were withheld from patients who } \\
\text { needed them } \\
\text { Calculated mean difference: }-0.03 \text { severe } \\
\text { exacerbations per subject per week, } 95 \% \\
\text { Cl: }-0.12 \text { to } 0.06 \text { (at } 12 \text { months after last } \\
\text { BT treatment) }\end{array}$ & $\begin{array}{l}1 \mathrm{RCT}^{3} \\
\mathrm{n}=112\end{array}$ & Medium $^{c}$ & $\begin{array}{l}\text { Indirect } \\
\text { (measured } \\
\text { while } \\
\text { patients off } \\
\text { LABA) }\end{array}$ & Unknown & Imprecise & $\begin{array}{l}\text { Not } \\
\text { detected }\end{array}$ & Insufficient \\
\hline
\end{tabular}




\begin{tabular}{|c|c|c|c|c|c|c|c|c|c|}
\hline Comparison & Outcome $^{a}$ & Study Results & $\begin{array}{c}\text { Study } \\
\text { Design and } \\
\text { Sample Size }\end{array}$ & $\begin{array}{c}\text { Study } \\
\text { Limitations }^{b}\end{array}$ & Directness & Consistency & Precision & $\begin{array}{l}\text { Reporting } \\
\text { Bias }\end{array}$ & $\begin{array}{c}\text { Overall } \\
\text { Evidence } \\
\text { Strength }\end{array}$ \\
\hline & $\begin{array}{l}\text { Exacerbations } \\
\text { Mild (after } \\
\text { treatment } \\
\text { period) }\end{array}$ & $\begin{array}{l}\text { Favors BT, but clinical importance } \\
\text { unclear: Rates of mild exacerbations per } \\
\text { patient per week were lower at } 12 \text { months } \\
\text { in patients who received BT and standard } \\
\text { care. } \\
\text { Exacerbations were counted while LABA } \\
\text { were withheld from patients who needed } \\
\text { them } \\
\text { Calculated mean difference: }-0.20 \text { mild } \\
\text { exacerbations per subject per week, } 95 \% \\
\text { Cl=-0.34 to }-0.06 \text { (at } 12 \text { months after last } \\
\text { BT treatment). Translates to } 10 \text { fewer mild } \\
\text { exacerbations per year, } 95 \% \mathrm{Cl}=3 \text { to } 18 \\
\text { fewer exacerbations. }\end{array}$ & $\begin{array}{l}1 \mathrm{RCT}^{3} \\
\mathrm{n}=112\end{array}$ & Medium $^{\mathrm{C}}$ & $\begin{array}{l}\text { Indirect: } \\
\text { measured } \\
\text { while } \\
\text { patients off } \\
\text { LABA for } 2 \\
\text { weeks }\end{array}$ & Unknown & Precise & $\begin{array}{l}\text { Not } \\
\text { detected }\end{array}$ & Low \\
\hline & $\begin{array}{l}\text { Hospitalizations } \\
\text { (after treatment } \\
\text { period) }\end{array}$ & $\begin{array}{l}\text { No difference: Rates of hospitalizations } \\
\text { were not different in patients who received } \\
\text { BT and standard care versus those treated } \\
\text { with standard care alone: } \\
\text { RISA: } 5 \text { hospitalizations in BT and } \\
\text { standard care vs. } 4 \text { hospitalizations in } \\
\text { standard care group, reported } p=0.32 \\
\text { AIR: } 3 \text { hospitalizations in } 3 \text { patients in BT } \\
\text { and standard care vs. } 3 \text { hospitalizations n } \\
2 \text { patients in standard care group, no } \\
\text { statistics reported }\end{array}$ & $\begin{array}{l}2 \mathrm{RCTs}^{2,3} \\
\mathrm{n}=144\end{array}$ & Medium $^{\mathrm{C}}$ & Direct & Consistent & Imprecise & $\begin{array}{l}\text { Not } \\
\text { detected }\end{array}$ & Low \\
\hline
\end{tabular}




\begin{tabular}{|c|c|c|c|c|c|c|c|c|c|}
\hline Comparison & Outcome $^{a}$ & Study Results & $\begin{array}{c}\text { Study } \\
\text { Design and } \\
\text { Sample Size }\end{array}$ & $\begin{array}{c}\text { Study } \\
\text { Limitations }^{b}\end{array}$ & Directness & Consistency & Precision & $\begin{array}{c}\text { Reporting } \\
\text { Bias }\end{array}$ & $\begin{array}{l}\text { Overall } \\
\text { Evidence } \\
\text { Strength }\end{array}$ \\
\hline & $\begin{array}{l}\text { Health care } \\
\text { utilization } \\
\text { (other than } \\
\text { exacerbations) }\end{array}$ & $\begin{array}{l}\text { Favors BT, but clinical importance } \\
\text { unclear: Use of rescue medication (puffs } \\
\text { per week) was reduced to a greater extent } \\
\text { in the BT group than standard care group } \\
\text { but does not meet the MID criterion } \\
\text { Calculated mean difference in number of } \\
\text { puffs per week for BT and standard care } \\
\text { compared to standard care alone: } \\
\text { AIR }^{3}:-7.8 \text { puffs/wk, } 95 \% \mathrm{Cl}=-14.78 \\
\text { to }-0.82 \text { (MID is }-5.67 \text { puffs/wk) } \\
\text { RISA }^{2} \text {-19.49 puffs/wk, } 95 \% \mathrm{Cl}=-35.5 \\
\text { to }-3.41 \text { (MID is }-5.67 \text { puffs/wk) } \\
\\
\text { The overall reduction in oral corticosteroid } \\
\text { dose was not different (p=0.12, Wilcoxon } \\
\text { sum rank test) between treatment groups } \\
\text { in } 1 \text { small trial. }{ }^{2} \text { The reduction in inhaled } \\
\text { corticosteroid dose was not different } \\
\text { (p=0.59, Wilcoxon sum rank test) }\end{array}$ & $\begin{array}{l}2 \mathrm{RCTs}^{2,3} \\
\mathrm{n}=144\end{array}$ & Medium $^{c}$ & Direct & Consistent & $\begin{array}{l}\text { Imprecise: } \\
\text { Upper } \\
\text { bounds of } \\
95 \% \text { Cls is } \\
\text { less than } \\
\text { MID }\end{array}$ & $\begin{array}{l}\text { Not } \\
\text { detected }\end{array}$ & LOW \\
\hline & $\begin{array}{l}\text { Pulmonary } \\
\text { physiology: } \\
\text { Spirometry }\end{array}$ & $\begin{array}{l}\text { Inconclusive: In } 1 \text { small trial, BT and } \\
\text { standard care improved FEV } 1 \text { at } 22 \text { weeks } \\
\text { from baseline; the between-group } \\
\text { difference was not significant at } 52 \text { weeks. }{ }^{2} \\
\text { In the other study, patients treated with BT } \\
\text { and standard care had greater increases in } \\
\text { morning and evening peak flow compared } \\
\text { with standard care alone from baseline to } \\
12 \text { months. Between-group change in } \\
\text { FEV }_{1} \text { was not significant. } \\
\end{array}$ & $\begin{array}{l}2 \mathrm{RCTS}^{2,3} \\
\mathrm{n}=144\end{array}$ & Medium $^{\mathrm{C}}$ & Direct & Inconsistent & Imprecise & $\begin{array}{l}\text { Not } \\
\text { detected }\end{array}$ & Insufficient \\
\hline & $\begin{array}{l}\text { Pulmonary } \\
\text { physiology: } \\
\text { Airway hyper- } \\
\text { responsiveness }\end{array}$ & $\begin{array}{l}\text { Inconclusive: Airway hyper- } \\
\text { responsiveness did not vary between } \\
\text { treatment groups }\end{array}$ & $\begin{array}{l}1 \mathrm{RCT}^{3} \\
\mathrm{n}=112\end{array}$ & Medium $^{c}$ & Direct & Unknown & Imprecise & $\begin{array}{l}\text { Not } \\
\text { detected }\end{array}$ & Insufficient \\
\hline
\end{tabular}




\begin{tabular}{|c|c|c|c|c|c|c|c|c|c|}
\hline Comparison & Outcome $^{a}$ & Study Results & $\begin{array}{c}\text { Study } \\
\text { Design and } \\
\text { Sample Size }\end{array}$ & $\begin{array}{c}\text { Study } \\
\text { Limitations }^{b}\end{array}$ & Directness & Consistency & Precision & $\begin{array}{c}\text { Reporting } \\
\text { Bias }\end{array}$ & $\begin{array}{c}\text { Overall } \\
\text { Evidence } \\
\text { Strength }\end{array}$ \\
\hline & Quality of life & $\begin{array}{l}\text { Favors BT, but clinical importance } \\
\text { unclear: AQLQ scores (scale 1-7, higher } \\
\text { indicating better quality of life, MID 0.5) } \\
\text { improved in patients who underwent BT } \\
\text { and received standard care compared to } \\
\text { those who received standard medical } \\
\text { management alone. } \\
\text { The result from the larger study did not } \\
\text { exceed the MID criterion (calculated mean } \\
\text { difference } 0.7,95 \% \mathrm{Cl}=0.28 \text { to } 1.12 \text { ) } \\
\text { Other calculated values: } \\
\text { AIR ( } n=112): \text { SMD } 0.62,95 \% \mathrm{Cl}=0.24 \text { to } \\
1.01(12 \text { months after last BT treatment) } \\
\text { RISA ( } n=32): \text { SMD } 1.38,95 \% \text { Cl } 0.60 \text { to } \\
2.15 \text { (46 weeks after last BT treatment) }\end{array}$ & $\begin{array}{l}2 \mathrm{RCTS}^{2,3} \\
\mathrm{n}=144\end{array}$ & Medium $^{\mathrm{c}}$ & Direct & Consistent & $\begin{array}{l}\text { Imprecise: } \\
\text { lower } \\
\text { bounds of } \\
\text { the } 95 \% \\
\text { Cl was } \\
\text { less than } \\
0.5, \text { the } \\
\text { MID for } \\
\text { AQLQ for } \\
\text { the larger } \\
\text { study }\end{array}$ & $\begin{array}{l}\text { Not } \\
\text { detected }\end{array}$ & Low \\
\hline & $\begin{array}{l}\text { Symptoms } \\
\text { (Secondary } \\
\text { outcome) }\end{array}$ & $\begin{array}{l}\text { Favors BT, but clinical importance } \\
\text { unclear: BT and standard care } \\
\text { significantly improved total symptom score } \\
\text { [range } 0 \text { to } 18 \text {, higher scores indicating } \\
\text { more symptoms] from baseline to } 12 \\
\text { months compared with medical } \\
\text { management alone } \\
\text { Calculated between-group mean difference } \\
\text { in total symptom score: }-1.20,95 \% \\
\text { Cl: }-2.10 \text { to }-0.30 \text { (no MID available; } \\
\text { Hedges g values suggest this is less than } \\
\text { an important difference) }\end{array}$ & $\begin{array}{l}1 \mathrm{RCT}^{3} \\
\mathrm{n}=112\end{array}$ & Medium $^{c}$ & Direct & Unknown & Precise & $\begin{array}{l}\text { Not } \\
\text { detected }\end{array}$ & Low \\
\hline $\begin{array}{l}\text { BT and } \\
\text { standard care } \\
\text { vs. sham } \\
\text { (bronchoscopy }\end{array}$ & Asthma control & $\begin{array}{l}\text { No difference: ACQ scores did not differ } \\
\text { at } 12 \text { months after either BT and standard } \\
\text { care or sham and standard care. } \\
\text { Calculated SMD:-0.05, } 95 \% \mathrm{Cl}:-0.29 \text { to } \\
0.19\end{array}$ & $\begin{array}{l}1 \mathrm{RCT}^{1} \\
\mathrm{n}=288\end{array}$ & Low & Direct & Unknown & Imprecise & \begin{tabular}{|l} 
Not \\
detected
\end{tabular} & Low \\
\hline
\end{tabular}




\begin{tabular}{|c|c|c|c|c|c|c|c|c|c|}
\hline Comparison & Outcome $^{a}$ & Study Results & $\begin{array}{c}\text { Study } \\
\text { Design and } \\
\text { Sample Size } \\
\end{array}$ & $\begin{array}{c}\text { Study } \\
\text { Limitations }^{b}\end{array}$ & Directness & Consistency & Precision & $\begin{array}{l}\text { Reporting } \\
\text { Bias }\end{array}$ & $\begin{array}{c}\text { Overall } \\
\text { Evidence } \\
\text { Strength }\end{array}$ \\
\hline \multirow[t]{4}{*}{$\begin{array}{l}\text { only) and } \\
\text { standard care }\end{array}$} & $\begin{array}{l}\text { Exacerbations: } \\
\text { Severe events } \\
\text { (after treatment } \\
\text { period) }\end{array}$ & $\begin{array}{l}\text { Favors BT, but clinical importance } \\
\text { unclear: Patients who underwent BT and } \\
\text { standard care had fewer severe } \\
\text { exacerbations per patient per year than } \\
\text { sham and standard care during weeks } 12 \\
\text { to } 52 \text {. Reported as } 0.48 \text { for BT vs. } 0.70 \text { for } \\
\text { Sham exacerbations/subject/year, PPS, } \\
95.5 \% \text {; FDA reports credible interval for } \\
\text { the difference: - } 0.031 \text { to } 0.520 \text {. } \\
\text { The number of patients experiencing } \\
\text { severe exacerbations was significantly less } \\
\text { in the BT group than sham group. } \\
\text { (Calculated RR: } 0.66,95 \% \text { Cl=0.47 to } \\
0.93 \text { ) }\end{array}$ & $\begin{array}{l}1 \mathrm{RCT}^{1} \\
\mathrm{n}=288\end{array}$ & Low & Direct & Unknown & $\begin{array}{l}\text { Imprecise: } \\
\text { reported } \\
\text { credible } \\
\text { interval } \\
\text { crosses } 0\end{array}$ & $\begin{array}{l}\text { Not } \\
\text { detected }\end{array}$ & Low \\
\hline & $\begin{array}{l}\text { Exacerbations: } \\
\text { Severe events } \\
\text { (during } \\
\text { treatment } \\
\text { period) }\end{array}$ & $\begin{array}{l}\text { Favors sham and standard care: During } \\
\text { the treatment period (up to } 6 \text { weeks } \\
\text { following the } 3^{\text {rd }} \text { BT or sham treatment), } \\
\text { the number of patients experiencing } \\
\text { severe exacerbations was significantly } \\
\text { higher in the BT group ( } 52 \text { of } 190) \text { than in } \\
\text { the sham group ( } 6 \text { of } 98) \text {; Calculated } \\
\text { RR: } 4.47,95 \% \mathrm{Cl}=1.99 \text { to } 10.04\end{array}$ & $\begin{array}{l}1 \mathrm{RCT}^{1} \\
\mathrm{n}=288\end{array}$ & Low & Direct & Unknown & Precise & $\begin{array}{l}\text { Not } \\
\text { detected }\end{array}$ & Moderate \\
\hline & $\begin{array}{l}\text { Exacerbations: } \\
\text { ED visits (after } \\
\text { treatment } \\
\text { period) }\end{array}$ & $\begin{array}{l}\text { Favors BT: Rates of ED visits for } \\
\text { respiratory symptoms were lower over } \\
12 \text { months following BT and standard care } \\
\text { relative to sham and standard care. } \\
\text { Reported as } 0.07 \text { vs. } 0.43 \text { visits/subject/yr; } \\
\text { PPS } 99.9 \% \text {; } \\
\text { FDA reported credible interval for sham } \\
\text { minus BT ( } 0.111 \text { to } 0.832)\end{array}$ & $\begin{array}{l}1 \mathrm{RCT}^{1} \\
\mathrm{n}=288\end{array}$ & Low & Direct & Unknown & Precise & $\begin{array}{l}\text { Not } \\
\text { detected }\end{array}$ & Moderate \\
\hline & $\begin{array}{l}\text { Exacerbations: } \\
\text { Hospitalizations } \\
\text { (after treatment } \\
\text { period) }\end{array}$ & $\begin{array}{l}\text { No difference: Hospitalizations for } \\
\text { respiratory symptoms after last BT } \\
\text { treatment to } 12 \text { month followup } \\
\text { Reported as } 5 \text { patients with } 6 \\
\text { hospitalizations in BT group; } 12 \\
\text { hospitalizations in } 4 \text { patients in sham } \\
\text { group; } \\
\text { Calculated RR: } 0.64,95 \% \mathrm{Cl}=0.18 \text { to } 2.35\end{array}$ & $\begin{array}{l}1 \mathrm{RCT}^{1} \\
\mathrm{n}=288\end{array}$ & Low & Direct & Unknown & $\begin{array}{l}\text { Imprecise: } \\
\text { lack of } \\
\text { precision } \\
\text { in } \\
\text { reporting } \\
\text { statistical } \\
\text { findings }\end{array}$ & $\begin{array}{l}\text { Not } \\
\text { detected }\end{array}$ & Low \\
\hline
\end{tabular}




\begin{tabular}{|c|c|c|c|c|c|c|c|c|c|}
\hline Comparison & Outcome $^{a}$ & Study Results & $\begin{array}{c}\text { Study } \\
\text { Design and } \\
\text { Sample Size }\end{array}$ & $\begin{array}{c}\text { Study } \\
\text { Limitations }^{b}\end{array}$ & Directness & Consistency & Precision & $\begin{array}{c}\text { Reporting } \\
\text { Bias }\end{array}$ & $\begin{array}{l}\text { Overall } \\
\text { Evidence } \\
\text { Strength }\end{array}$ \\
\hline & $\begin{array}{l}\text { Exacerbations: } \\
\text { Hospitalizations } \\
\text { (during } \\
\text { treatment } \\
\text { period) }\end{array}$ & $\begin{array}{l}\text { No difference: Hospitalizations for } \\
\text { respiratory symptoms during the treatment } \\
\text { period (up to } 6 \text { weeks following the } 3^{\text {rd }} \text { BT } \\
\text { or sham treatment) were higher in the BT } \\
\text { group than the sham group } \\
\text { Reported as } 16 \text { patients with19 } \\
\text { hospitalizations in BT group, } 2 \text { patients } \\
\text { with } 2 \text { hospitalizations in sham; Calculated } \\
\text { RR: } 4.13,95 \% \mathrm{Cl}=0.97 \text { to } 17.58 \text { ) }\end{array}$ & $\begin{array}{l}1 \mathrm{RCT}^{1} \\
\mathrm{n}=288\end{array}$ & Low & Direct & Unknown & Imprecise & \begin{tabular}{|l|} 
Not \\
detected
\end{tabular} & Low \\
\hline & $\begin{array}{l}\text { Health care } \\
\text { utilization: } \\
\text { Rescue } \\
\text { medication } \\
\text { actuations }\end{array}$ & $\begin{array}{l}\text { No difference: Use of rescue medication } \\
\text { at } 12 \text { month followup (MID is }-5.67 \\
\text { puffs/wk) } \\
\text { Calculated difference in means: }-1.7 \\
\text { puffs/wk, } 95 \% \mathrm{Cl}-5.56 \text { to } 2.16 \text { puffs }\end{array}$ & $\begin{array}{l}1 \mathrm{RCT}^{1} \\
\mathrm{n}=288\end{array}$ & Low & Direct & Unknown & Imprecise & $\begin{array}{l}\text { Not } \\
\text { detected }\end{array}$ & Low \\
\hline & $\begin{array}{l}\text { Health care } \\
\text { utilization: } \\
\text { Days rescue } \\
\text { medication } \\
\text { required }\end{array}$ & $\begin{array}{l}\text { No difference: } \% \text { days rescue medication } \\
\text { used at } 12 \text { month followup } \\
\text { Calculated difference in means: }-2.1 \% \text {, } \\
95 \% \mathrm{Cl}=-10.86 \% \text { to } 6.66 \%\end{array}$ & $\begin{array}{l}1 \mathrm{RCT}^{1} \\
\mathrm{n}=288\end{array}$ & Low & Direct & Unknown & Imprecise & \begin{tabular}{|l} 
Not \\
detected
\end{tabular} & Low \\
\hline & $\begin{array}{l}\text { Pulmonary } \\
\text { physiology }\end{array}$ & $\begin{array}{l}\text { No difference: } \mathrm{FEV}_{1} \text { and morning peak } \\
\text { flow in patients treated with BT and } \\
\text { standard care compared with sham and } \\
\text { standard care from baseline to } 12 \text { months }\end{array}$ & $\begin{array}{l}1 \mathrm{RCT}^{1} \\
\mathrm{n}=288\end{array}$ & Low & Direct & Unknown & Imprecise & $\begin{array}{l}\text { Not } \\
\text { detected }\end{array}$ & Low \\
\hline
\end{tabular}




\begin{tabular}{|c|c|c|c|c|c|c|c|c|c|}
\hline Comparison & Outcome $^{a}$ & Study Results & $\begin{array}{c}\text { Study } \\
\text { Design and } \\
\text { Sample Size }\end{array}$ & $\begin{array}{c}\text { Study } \\
\text { Limitations }^{b}\end{array}$ & Directness & Consistency & Precision & $\begin{array}{c}\text { Reporting } \\
\text { Bias }\end{array}$ & $\begin{array}{c}\text { Overall } \\
\text { Evidence } \\
\text { Strength }\end{array}$ \\
\hline & Quality of life & $\begin{array}{l}\text { Inconclusive: } \\
\text { Change in AQLQ scores did not differ in } \\
\text { intent-to-treat patients } 12 \text { months after } \\
\text { either BT and standard care or sham } \\
\text { intervention and standard care } \\
\text { Reported in FDA presentation as a } \\
\text { difference of 0.21 on the AQLQ 7-point } \\
\text { scale (PPS 96\%) (below MID of 0.5); } \\
\text { credible interval -0.025 to 0.445. } \\
\text { AQLQ improved in per-protocol patients } \\
\text { treated with BT and standard care } \\
\text { compared with sham and standard care at } \\
12 \text { months. Reported in FDA presentation } \\
\text { as a difference of 0.24, PPS 97.9\% (below } \\
\text { MID of 0.5); credible interval 0.009 to, } \\
0.478 . \\
\text { The proportion of patients with } \\
\text { improvement in AQLQ score greater than } \\
\text { the minimum important difference was } \\
\text { higher after BT and standard care than } \\
\text { after the sham intervention and standard } \\
\text { care. Reported in FDA presentation as } \\
\text { "150 of } 190 \text { patients in BT group, } 63 \text { of } 98 \\
\text { in sham group, a difference of } 14.6 \% \\
\text { favoring BT, but with no control for type I } \\
\text { error, and this was not a prespecified } \\
\text { outcome." }\end{array}$ & $\begin{array}{l}1 \mathrm{RCT}^{1} \\
\text { intent-to- } \\
\text { treat: } \mathrm{n}=288 \\
\text { per protocol: } \\
\mathrm{n}=268\end{array}$ & $\begin{array}{l}\text { Low for ITT } \\
\text { analysis and } \\
\text { responder } \\
\text { analysis; } \\
\text { Medium for } \\
\text { per protocol } \\
\text { analysis }\end{array}$ & Direct & Unknown & $\begin{array}{l}\text { Imprecise: } \\
95 \% \\
\text { credible } \\
\text { interval for } \\
\text { continuous } \\
\text { measure } \\
\text { crosses } 0 \\
\text { in the } \\
\text { intent-to- } \\
\text { treat } \\
\text { patients; } \\
\text { the result } \\
\text { and upper } \\
\text { bound of } \\
\text { the } \\
\text { credible } \\
\text { interval is } \\
\text { less than } \\
\text { MID in the } \\
\text { per- } \\
\text { protocol } \\
\text { population }\end{array}$ & $\begin{array}{l}\text { Possible } \\
\text { selective } \\
\text { outcome } \\
\text { reporting. } \\
\text { This } \\
\text { outcome } \\
\text { was not } \\
\text { prespecified }\end{array}$ & Insufficient \\
\hline & $\begin{array}{l}\text { Symptoms } \\
\text { (Secondary } \\
\text { outcome) }\end{array}$ & $\begin{array}{l}\text { No difference: Symptom scores (scale } 0 \\
\text { to } 18, \text { higher score indicating more } \\
\text { symptoms) improved over time in both } \\
\text { treatment groups but did not differ as a } \\
\text { function of treatment condition } \\
\text { Calculated mean difference }-0.10,95 \% \\
\mathrm{Cl}=-0.66 \text { to } 0.46\end{array}$ & $\begin{array}{l}1 \mathrm{RCT}^{1} \\
\mathrm{n}=288\end{array}$ & Low & Direct & Unknown & Imprecise & $\begin{array}{l}\text { Not } \\
\text { detected }\end{array}$ & Low \\
\hline
\end{tabular}




\begin{tabular}{|c|c|c|c|c|c|c|c|c|c|}
\hline Comparison & Outcome $^{\mathrm{a}}$ & Study Results & $\begin{array}{c}\text { Study } \\
\text { Design and } \\
\text { Sample Size }\end{array}$ & $\begin{array}{c}\text { Study } \\
\text { Limitations }^{b}\end{array}$ & Directness & Consistency & Precision & $\begin{array}{l}\text { Reporting } \\
\text { Bias }\end{array}$ & $\begin{array}{l}\text { Overall } \\
\text { Evidence } \\
\text { Strength } \\
\end{array}$ \\
\hline \multirow[t]{6}{*}{$\begin{array}{l}\text { BT in RCT } \\
\text { patients vs. } \\
\text { BT in "real } \\
\text { world" clinic } \\
\text { patients }\end{array}$} & Asthma control & $\begin{array}{l}\text { Inconclusive: Although ACQ scores were } \\
\text { significantly better following BT in patients } \\
\text { who were enrolled in the RCTs compared } \\
\text { to the patients from clinic who underwent } \\
\text { BT, this } 1 \text { small nonrandomized study is } \\
\text { insufficient for drawing a conclusion. The } \\
\text { change from baseline in each group was } \\
\text { clinically significant. }\end{array}$ & $\begin{array}{l}1 \text { non-RCT } \\
n=25\end{array}$ & High $^{d}$ & Direct & Unknown & Imprecise & $\begin{array}{l}\text { Not } \\
\text { detected }\end{array}$ & Insufficient \\
\hline & Exacerbations & $\begin{array}{l}\text { Inconclusive: Rates of exacerbations } \\
\text { were low in both treatment groups and did } \\
\text { not vary statistically }\end{array}$ & $\begin{array}{l}1 \text { non-RCT5 } \\
n=25\end{array}$ & High $^{d}$ & Direct & Unknown & Imprecise & $\begin{array}{l}\text { Not } \\
\text { detected }\end{array}$ & Insufficient \\
\hline & $\begin{array}{l}\text { Health care } \\
\text { utilization }\end{array}$ & $\begin{array}{l}\text { Not evaluable: Data on hospitalizations } \\
\text { and medication use not reported in a } \\
\text { comparable manner for treatment groups }\end{array}$ & NA & NA & NA & NA & NA & NA & NA \\
\hline & $\begin{array}{l}\text { Pulmonary } \\
\text { physiology }\end{array}$ & $\begin{array}{l}\text { Inconclusive: } \mathrm{FEV}_{1} \text { did not differ } \\
\text { significantly between groups }\end{array}$ & $\begin{array}{l}1 \text { non-RCT } \\
\mathrm{n}=25\end{array}$ & High $^{d}$ & Direct & Unknown & Imprecise & \begin{tabular}{|l|} 
Not \\
detected
\end{tabular} & Insufficient \\
\hline & Quality of life & $\begin{array}{l}\text { Inconclusive: AQLQ scores improved to a } \\
\text { clinically significant degree in both } \\
\text { treatment groups; difference between } \\
\text { groups not significantly different, but } \\
\text { sample size was small }\end{array}$ & $\begin{array}{l}1 \text { non-RCT } \\
n=25\end{array}$ & High $^{d}$ & Direct & Unknown & Imprecise & $\begin{array}{l}\text { Not } \\
\text { detected }\end{array}$ & Insufficient \\
\hline & $\begin{array}{l}\text { Symptoms } \\
\text { (Secondary } \\
\text { outcome) }\end{array}$ & Not evaluable: Not reported & NA & NA & NA & NA & NA & NA & NA \\
\hline
\end{tabular}

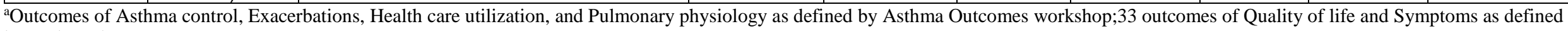
by study authors.

bStudy limitations derived from Risk of Bias assessments in Appendix C.

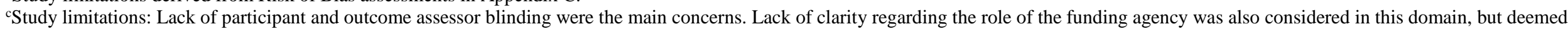
a lesser concern.

${ }^{\mathrm{d}}$ Observational study, retrospective, groups not comparable on baseline characteristics

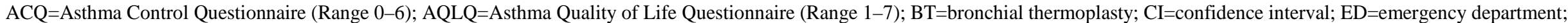

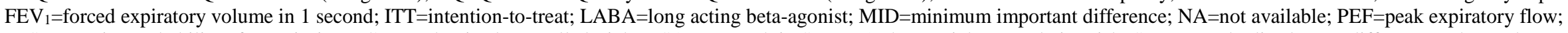

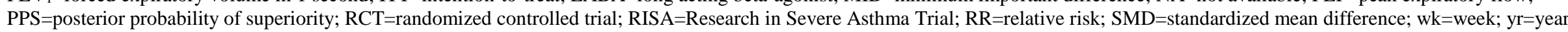


Table C-5. Study and patient characteristics of descriptive studies (case reports and case series)

\begin{tabular}{|c|c|c|c|c|}
\hline Study & Intervention & Study Design & Demographic Factors & $\begin{aligned} \text { Clinical Factors } \\
\end{aligned}$ \\
\hline $\begin{array}{l}\text { McCambridge et al. } \\
2016^{8}\end{array}$ & BT & $\begin{array}{l}\text { Type of study: Case Study } \\
\text { Total population: } \mathrm{N}=1 \\
\text { Country: U.S. } \\
\text { Followup: } 6 \text { months }\end{array}$ & $\begin{array}{l}\text { Age: } 77 \text { years } \\
\text { Sex: Female } \\
\text { Race: NR }\end{array}$ & $\begin{array}{l}\text { Inhaled corticosteroid dose: NR } \\
\text { FEV }: \text { NR } \\
P C_{20}: \text { NR } \\
\text { Asthma severity: Severe, Step NR } \\
\text { Comorbidity: NR }\end{array}$ \\
\hline Nguyen et al. $2016^{9}$ & BT & $\begin{array}{l}\text { Type of study: Case Study } \\
\text { Total population: } \mathrm{N}=1 \\
\text { Country: U.S. } \\
\text { Followup: } 3 \text { days for complications }\end{array}$ & $\begin{array}{l}\text { Age: } 66 \text { years } \\
\text { Sex: Female } \\
\text { Race: NR }\end{array}$ & $\begin{array}{l}\text { Inhaled corticosteroid dose: NR } \\
\text { FEV } 1 \text { NR } \\
\text { PC } 20: \text { NR } \\
\text { Asthma severity: Severe, Step NR } \\
\text { Comorbidity: Hypertension }\end{array}$ \\
\hline Balu et al. $2015^{10}$ & BT & $\begin{array}{l}\text { Type of study: Case Study } \\
\text { Total population: } \mathrm{N}=1 \\
\text { Country: U.K. } \\
\text { Followup: } 9 \text { weeks }\end{array}$ & $\begin{array}{l}\text { Age: } 43 \text { years } \\
\text { Sex: Female } \\
\text { Race: Caucasian }\end{array}$ & $\begin{array}{l}\text { Inhaled corticosteroid dose: NR } \\
\text { FEV }: \text { Pre-bronchodilator } \\
\text { PC } 20: \text { NR } \\
\text { Asthma severity: Severe; Step } 5 \\
\text { Comorbidity: Bipolar disorder }\end{array}$ \\
\hline $\begin{array}{l}\text { Facciolongo et al. } \\
2015^{11}\end{array}$ & BT & $\begin{array}{l}\text { Type of study: Case Study } \\
\text { Total population: } \mathrm{N}=1 \\
\text { Country: Italy } \\
\text { Followup: } 12 \text { months }\end{array}$ & $\begin{array}{l}\text { Age: } 49 \text { years } \\
\text { Sex: Male } \\
\text { Race: Caucasian }\end{array}$ & $\begin{array}{l}\text { Inhaled corticosteroid dose: Budesonide/formoterol } \\
\text { Dosage: } 800 / 24 \text { mcg/d } \\
\text { FEV } 1 \text { : Pre-bronchodilator, } 66 \% \text { predicted } \\
\text { PC } 20: \text { NR } \\
\text { Asthma severity: Severe, Step NR } \\
\text { Comorbidity: Common variable immunodeficiency }\end{array}$ \\
\hline Doeing et al. $2013^{12}$ & BT & $\begin{array}{l}\text { Type of study: Case Study } \\
\text { Total population: } \mathrm{N}=1 \\
\text { Country: U.S. } \\
\text { Followup: } 6 \text { months }\end{array}$ & $\begin{array}{l}\text { Mean age: } 62 \text { years } \\
\text { Sex: Female } \\
\text { Race: Caucasian }\end{array}$ & $\begin{array}{l}\text { Inhaled corticosteroid dose: Fluticasone/salmeterol } \\
\text { Dosage: } 500 / 50 \text { mcg/d } \\
\text { FEV } 1 \text { : Pre-bronchodilator, } 26 \% \text { predicted } \\
\text { Asthma severity: STEP } 6 \\
\text { Comorbidity: Gastroesophageal reflux disease and obstructive } \\
\text { sleep apnea }\end{array}$ \\
\hline Doeing et al. $2013^{13}$ & BT & $\begin{array}{l}\text { Type of study: Retrospective, } \\
\text { observational } \\
\text { Total population: } \mathrm{N}=8 \\
\text { Country: U.S. } \\
\text { Followup: Up to } 72 \text { weeks }\end{array}$ & $\begin{array}{l}\text { Mean age (SEM): } 47(4.3) \\
\text { years } \\
\text { Sex: } 50 \% \text { male } \\
\text { Race: } 63 \% \text { Caucasian }\end{array}$ & $\begin{array}{l}\text { Inhaled corticosteroid dose: Fluticasone or equivalent } \\
\text { Dosage: } 1,000 \mathrm{mcg} / \mathrm{d} \\
\text { FEV } 1 \text { : Pre-bronchodilator, } 51.8 \% \text { (8.6) predicted } \\
\text { Asthma severity: STEP } 5 \text { or } 6 \\
\text { Comorbidity: NR }\end{array}$ \\
\hline Mahajan et al. $2012^{14}$ & BT & $\begin{array}{l}\text { Type of study: Case study } \\
\text { Total population: } \mathrm{N}=1 \\
\text { Country: U.S. } \\
\text { Followup: } 1 \text { year }\end{array}$ & $\begin{array}{l}\text { Age: } 42 \text { years } \\
\text { Sex: Female } \\
\text { Race: South Asian }\end{array}$ & $\begin{array}{l}\text { Inhaled corticosteroid dose: Fluticasone } \\
\text { Dosage: } 1,000 \mathrm{mcg} / \mathrm{d} \\
\text { FEV } 1: 0.95 \mathrm{~L} \\
\text { Asthma severity: Severe; Step NR } \\
\text { Comorbidity: History of eczema and recurrent sinus infections; } \\
\text { unable to tolerate oral corticosteroids due to the dysphoria and } \\
\text { suicidal ideations }\end{array}$ \\
\hline
\end{tabular}




\begin{tabular}{|c|c|c|c|c|}
\hline Study & Intervention & Study Design & Demographic Factors & Clinical Factors \\
\hline Cox et al. $2006^{15}$ & BT & $\begin{array}{l}\text { Type of study: Prospective, } \\
\text { observational } \\
\text { Total population: } \mathrm{N}=16 \\
\text { Country: Canada } \\
\text { Followup: } 2 \text { year }\end{array}$ & $\begin{array}{l}\text { Mean age (range): } 39 \\
\text { years }(24-58) \\
\text { Sex: } 38 \% \text { male } \\
\text { Race: } 94 \% \text { Caucasian }\end{array}$ & $\begin{array}{l}\text { Inhaled corticosteroid dose: Fluticasone or equivalent } \\
\text { Dosage (\% of patients) } \\
\text { None: } 1(6.3 \%) \\
\text { Low dose }<250 \mathrm{mcg} / \mathrm{d}: 1(6.3 \%) \\
\text { Medium dose } 250-500 \mathrm{mcg} / \mathrm{d}: 13(81.3 \%) \\
\text { High dose }>500 \mathrm{mcg} / \mathrm{d}: 1(6.3 \%) \\
\text { FEV } 1 \text { : Pre-bronchodilator, } 82.28 \%(13.97) \text { predicted } \\
\text { PC } 20 \text { (95\% CI): } 0.92(0.42-1.99) \\
\text { Asthma severity: Severe; Step NR } \\
\text { Comorbidity: NR }\end{array}$ \\
\hline
\end{tabular}

$\mathrm{BT}=$ bronchial thermoplasty; $\mathrm{CI}=$ confidence interval; $\mathrm{FEV}_{1}=$ forced expiratory volume; $\mathrm{NR}=$ not reported; $\mathrm{PC}_{20}=$ provocative concentration of methacholine causing a $20 \%$ drop in FEV 1 ;

RCT=randomized clinical trial; SD=standard deviation; SEM=standard error of the mean; U.K.=United Kingdom; U.S.=United States

Table C-6. Outcomes of descriptive bronchial thermoplasty studies (case reports and case series)

\begin{tabular}{|c|c|}
\hline Reference & 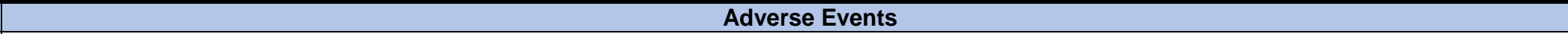 \\
\hline $\begin{array}{l}\text { McCambridge et al. } \\
2016^{8}\end{array}$ & 7 days after BT, bilateral bronchial wall thickening, which resolved by 40 days after BT \\
\hline Nguyen et al. $2016^{9}$ & $\begin{array}{l}\text { Adverse events } \\
\text { Distress, wheezing, tachycardia, inspiratory lung crackles, diminished breath sounds, reddened airways, dynamic airway collapse and mucous plugging } \\
\text { Serious adverse events } \\
\text { Pulmonary embolism with pleural effusion requiring mechanical ventilation } \\
\text { Bilateral lower extremity deep venous thrombi } \\
\text { Hemothorax with bleeding from bronchial artery pseudoaneurysm while anticoagulated for venous thromboemboli }\end{array}$ \\
\hline Balu et al. $2015^{10}$ & $\begin{array}{l}\text { Lung abscess in area of BT treatment with associated asthma exacerbation; treated with intravenous antibiotics followed by prolonged course of oral } \\
\text { antibiotics }\end{array}$ \\
\hline $\begin{array}{l}\text { Facciolongo et al. } \\
2015^{11}\end{array}$ & $\begin{array}{l}\text { First BT session: } \\
\text { Acute respiratory failure, reduced breath sounds, severe bronchospasm with tachypnea, atelectasis, lung occlusion by bronchus-shaped plugs } \\
\text { Second BT session: } \\
\text { Severe bronchospasm with respiratory failure, atelectasis, mucus plug occluding bronchus }\end{array}$ \\
\hline Doeing $2013^{12}$ & $\begin{array}{l}\text { First BT procedure: } \\
\text { Hospitalized overnight due to requiring frequent nebulized albuterol treatments } \\
\text { Second BT procedure: } \\
\text { Asthma exacerbation } \\
\text { Final BT procedure: } \\
\text { Hospitalized overnight due to requiring frequent nebulized albuterol treatments }\end{array}$ \\
\hline Doeing $2013^{13}$ & $\begin{array}{l}\text { After initial BT procedure: } \\
\text { Patients }(n=4) \text { required overnight observation due to wheezing and/or increased frequency of rescue bronchodilator use } \\
\text { After second BT procedure: } \\
\text { Patients }(n=2) \text { required overnight observation: one had atelectasis; one required increased bronchodilator use } \\
\text { After third BT procedure: } \\
\text { Patients }(n=3) \text { required overnight observation: two required admissions for frequent bronchodilator use and one had a lower respiratory tract infection } \\
\text { One additional patient developed mild hemoptysis and lower respiratory tract infection }\end{array}$ \\
\hline
\end{tabular}




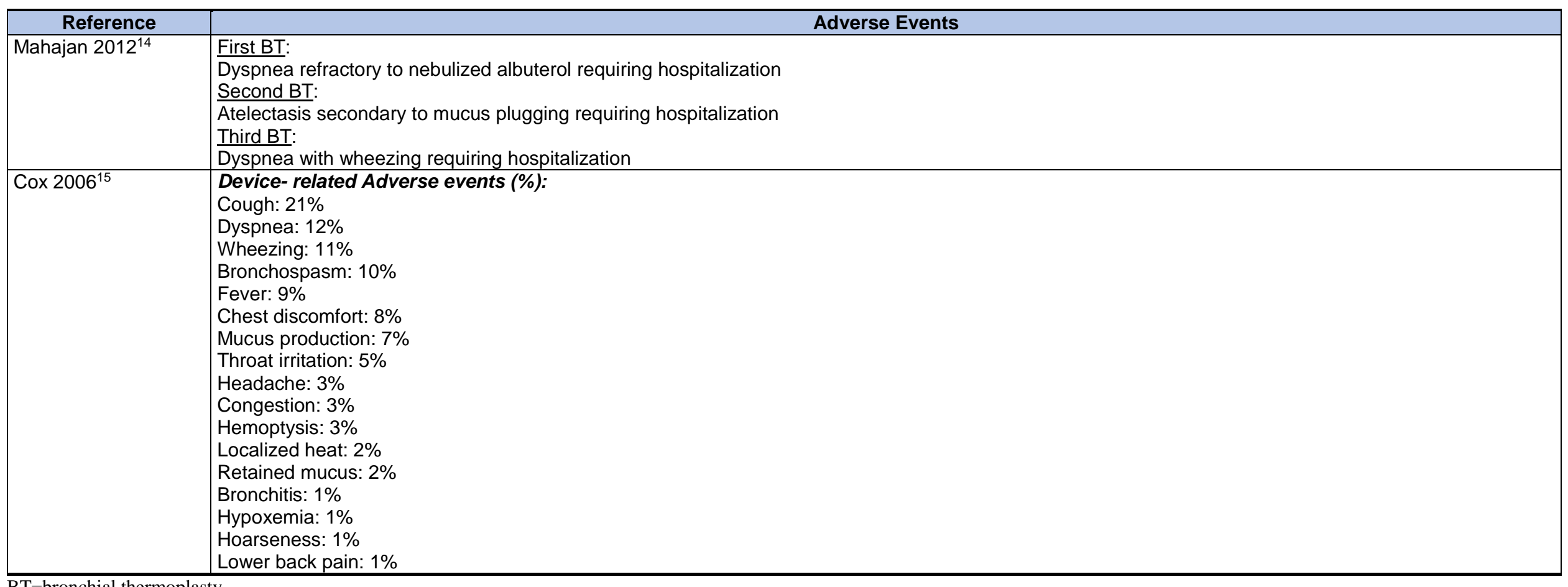

BT=bronchial thermoplasty 


\section{Appendix D. Minimally Important Differences for Asthma Study Outcomes}

It is important to evaluate whether a measured change in an asthma outcome is clinically meaningful as well as statistically significant. Thresholds for determining clinically significant improvement have been established for some measures of asthma control, asthma-related quality of life, pulmonary physiology, and healthcare utilization, and are presented in Table E-1. The data in this table are reproduced with permission from the AHRQ EPC report, "Systematic Review of Intermittent Inhaled Corticosteroids and of Long-acting Muscarinic Antagonists for Asthma,” by the University of Connecticut Evidence-based Practice Center.

Table D-1. Thresholds for clinical significance

\begin{tabular}{|c|c|c|c|}
\hline Instrument/ Outcome & Range (points) & Final score & Threshold \\
\hline ACT & 5 to 25 & $\begin{array}{l}\text { Well controlled: } \geq 20 \\
\text { Not well controlled: } \leq 19\end{array}$ & $\geq 12$ y: $\Delta 3$ points $^{16}$ \\
\hline ACQ5, ACQ6 & 0 to 6 & $\begin{array}{l}\text { Uncontrolled: } \geq 1.5 \\
\text { Well-controlled: }<0.75\end{array}$ & $\geq 18$ y: $\Delta 0.5$ points $^{17}$ \\
\hline ACQ7 & 0 to 6 & $\begin{array}{l}\text { Uncontrolled: } \geq 1.5 \\
\text { Well-controlled: }<0.75\end{array}$ & $\geq 6$ y: $\Delta 0.5$ points $^{17,18}$ \\
\hline AQLQ,AQLQ(S), AQLQ-mini & 1 to 7 & $\begin{array}{l}\text { Severe impairment }=1 \\
\text { No impairment }=7\end{array}$ & $\geq 18$ y: $\Delta 0.5$ points $^{19-21}$ \\
\hline AQLQ12+ & 1 to 7 & $\begin{array}{l}\text { Severe impairment }=1 \\
\text { No impairment }=7\end{array}$ & $\geq 12$ y: $\Delta 0.5$ points ${ }^{22,23}$ \\
\hline PAQLQ, PACQLQ & 1 to 7 & $\begin{array}{l}\text { Severe impairment }=1 \\
\text { No impairment }=7\end{array}$ & $7-17$ y: $\Delta 0.5$ points $^{24,25}$ \\
\hline FEV1 & Continuous measure, L & NA & $\geq 18$ y: $-0.2 L^{26}$ \\
\hline Rescue medication use & $\begin{array}{l}\text { Continuous measure, } \\
\text { puffs per unit of time }\end{array}$ & NA & $\geq 18$ y: -0.81 puffs $/$ day $^{26}$ \\
\hline
\end{tabular}

$\mathrm{ACT}=$ asthma control test; $\mathrm{ACQ}=$ asthma control questionnaire; $\mathrm{AQLQ}=$ asthma quality of life questionnaire; AQLQ-mini=asthma quality of life questionnaire-15 items;

AQLQ(S)=Sydney asthma quality of life questionnaire or Asthma quality of life questionnaire-standardized version

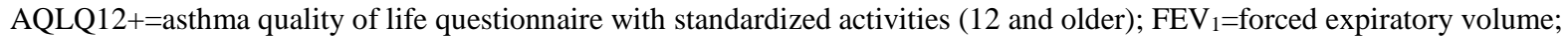
NA=not available; PACQLQ=pediatric asthma caregiver's quality of life questionnaire; PAQLQ=pediatric asthma quality of life questionnaire 


\section{Appendix E. Ongoing Clinical Trials}

Table E-1. Ongoing clinical trials

\begin{tabular}{|c|c|c|c|}
\hline $\begin{array}{l}\text { Study Name } \\
\text { NCT Identifier } \\
\text { Sponsor }\end{array}$ & Planned Enrollment & $\begin{array}{l}\text { Study Design and Objective } \\
\text { Primary Endpoints }\end{array}$ & $\begin{array}{l}\text { Estimated Final } \\
\text { Completion Date }\end{array}$ \\
\hline $\begin{array}{l}\text { RISA Extension Study - Long Term } \\
\text { Safety } \\
\text { NCT00401986 } \\
\text { Asthmatx, Inc. }\end{array}$ & $\begin{array}{l}\mathrm{n}=15 \text { patients with severe uncontrolled } \\
\text { asthma; enrollment limited to patients who } \\
\text { participated in the RISA Trial } \\
\text { (NCT00214539). }\end{array}$ & $\begin{array}{l}\text { Prospective observational cohort study evaluating long-term } \\
\text { safety of BT } \\
\text { Primary endpoint: Not provided }\end{array}$ & $\begin{array}{l}\text { No completion date } \\
\text { provided; status of trial is } \\
\text { listed as unknown, but is } \\
\text { linked to Pavord et al. } \\
2013^{6}\end{array}$ \\
\hline $\begin{array}{l}\text { Efficacy of Bronchial Thermoplasty in } \\
\text { Korean } \\
\text { NCT02031263 } \\
\text { Asan Medical Center }\end{array}$ & $\begin{array}{l}\mathrm{n}=9 \text { patients with severe uncontrolled } \\
\text { asthma }\end{array}$ & $\begin{array}{l}\text { Open-label, single-arm trial investigating the safety and efficacy } \\
\text { of BT in a Korean population } \\
\text { Primary endpoint: Changes in the Quality of Life Questionnaire } \\
\text { for Adult Korean Asthmatics from baseline to } 3 \text { month post- } \\
\text { treatment }\end{array}$ & $\begin{array}{l}\text { February } 2015 \\
\text { The status of this trial is } \\
\text { unknown }\end{array}$ \\
\hline $\begin{array}{l}\text { Bronchial Thermoplasty: Effect on } \\
\text { Neuronal and Chemosensitive } \\
\text { Component of the Bronchial Mucosa } \\
\text { NCT01839591 } \\
\text { Arcispedale Santa Maria Nuova- } \\
\text { IRCCS }\end{array}$ & $\begin{array}{l}n=12 \text { patients with severe uncontrolled } \\
\text { asthma }\end{array}$ & $\begin{array}{l}\text { Open-label, single-arm trial investigating the safety and efficacy } \\
\text { of BT, and the impact of BT on potential sources of } \\
\text { bronchospasm in the bronchial mucosa } \\
\text { Primary endpoint: Changes in ACT and AQLQ scores from } \\
\text { baseline to one year post-treatment }\end{array}$ & $\begin{array}{l}\text { December } 2015 \\
\text { The status of this trial is } \\
\text { unknown }\end{array}$ \\
\hline $\begin{array}{l}\text { Spirometric Response to Bronchial } \\
\text { Thermoplasty in Patients With Severe } \\
\text { Asthma } \\
\text { NCT02241265 } \\
\text { University of Oklahoma }\end{array}$ & $\mathrm{n}=20$ patients with severe asthma & $\begin{array}{l}\text { Open-label, single-arm trial assessing the impact of BT on } \\
\text { FEV }_{1} \\
\text { Primary endpoint: Changes in prebronchodilator FEV }{ }_{1} \text { and FVC } \\
\text { from baseline to } 12 \text { months post-treatment }\end{array}$ & $\begin{array}{l}\text { July } 2016 \\
\text { The status of this trial is } \\
\text { unknown }\end{array}$ \\
\hline $\begin{array}{l}\text { Study of Physiopathological } \\
\text { Mechanisms and Results of Treatment } \\
\text { With Bronchial Thermoplasty in } \\
\text { Severe Asthma } \\
\text { NCT01974921 } \\
\text { Fundació Institut de Recerca de } \\
\text { l'Hospital de la Santa Creu i Sant Pau }\end{array}$ & $\begin{array}{l}n=15 \text { patients with severe asthma and at } \\
\text { least } 2 \text { exacerbations in the past year }\end{array}$ & $\begin{array}{l}\text { Open-label, single-arm trial investigating the safety, efficacy, } \\
\text { and histology of BT } \\
\text { Primary endpoint: Changes in bronchial smooth muscle from } \\
\text { baseline to } 6 \text { months post-treatment }\end{array}$ & $\begin{array}{l}\text { September } 2016 \\
\text { This trial is listed as still } \\
\text { recruiting }\end{array}$ \\
\hline
\end{tabular}




\begin{tabular}{|c|c|c|c|}
\hline $\begin{array}{l}\text { Study Name } \\
\text { NCT Identifier } \\
\text { Sponsor }\end{array}$ & Planned Enrollment & $\begin{array}{l}\text { Study Design and Objective } \\
\text { Primary Endpoints }\end{array}$ & $\begin{array}{l}\text { Estimated Final } \\
\text { Completion Date }\end{array}$ \\
\hline $\begin{array}{l}\text { Bronchial Thermoplasty for Severe } \\
\text { Asthmatics Guided by HXe MRI } \\
\text { NCT01832363 } \\
\text { Xemed LLC } \\
\text { Collaborators: } \\
\text { National Institutes of Health (NIH) } \\
\text { National Heart, Lung, and Blood } \\
\text { Institute (NHLBI) } \\
\text { Washington University School of } \\
\text { Medicine } \\
\text { University of Virginia }\end{array}$ & $\mathrm{n}=30$ patients with severe asthma & $\begin{array}{l}\text { Double-blind (patient, outcome assessor) RCT to determine the } \\
\text { utility of using hyperpolarized xenon (HXe) lung MRI to guide } \\
\text { BT (HXe-guided BT vs. Standard BT) } \\
\text { Primary endpoint: Change in AQLQ scores from baseline to } \\
2.5 \text { years post-treatment }\end{array}$ & August 2017 \\
\hline $\begin{array}{l}\text { Bicentric Prospective Study, } \\
\text { Evaluating Bronchial Thermoplasty in } \\
\text { a Patient Presenting Severe } \\
\text { Uncontrolled Asthma (ASMATHERM) } \\
\text { NCT01777360 } \\
\text { Assistance Publique - Hôpitaux de } \\
\text { Paris } \\
\text { Collaborator: } \\
\text { Boston Scientific Corporation }\end{array}$ & $\begin{array}{l}\mathrm{n}=46 \text { patients with severe uncontrolled } \\
\text { asthma receiving optimal treatment and } \\
\text { experiencing at least one exacerbation } \\
\text { requiring oral steroids in the past year }\end{array}$ & $\begin{array}{l}\text { Open-label, single-arm trial designed to determine which } \\
\text { patients might be "best candidates" for BT } \\
\text { Primary endpoint: Reduction in smooth muscle surface area } \\
\text { from baseline to } 3 \text { months post-treatment }\end{array}$ & September 2017 \\
\hline $\begin{array}{l}\text { Effect of Bronchial Thermoplasty on } \\
\text { Moderate Bronchial Asthma in China } \\
\text { NCT02965807 } \\
\text { Guangzhou Institute of Respiratory } \\
\text { Disease }\end{array}$ & $\mathrm{n}=50$ patients with moderate asthma & $\begin{array}{l}\text { Open-label, single-arm trial investigating the safety and efficacy } \\
\text { of BT } \\
\text { Primary endpoint: Change in AQLQ from baseline over a } \\
\text { 12-month period }\end{array}$ & December 2017 \\
\hline $\begin{array}{l}\text { Unravelling Targets of Therapy in } \\
\text { Bronchial Thermoplasty in Severe } \\
\text { Asthma (TASMA) } \\
\text { NCT02225392 } \\
\text { Academisch Medisch Centrum - } \\
\text { Universiteit van Amsterdam } \\
\text { (AMC-UvA) } \\
\text { Collaborators: } \\
\text { ZonMw: The Netherlands Organisation } \\
\text { for Health Research and Development } \\
\text { The Netherlands Asthma Foundation } \\
\text { Boston Scientific Corporation }\end{array}$ & $\mathrm{n}=40$ patients with severe asthma & $\begin{array}{l}\text { Non-blinded RCT comparing patients who undergo immediate } \\
\text { BT to a control group (BT delayed until after primary endpoint } \\
\text { for immediate BT group-25 weeks) } \\
\text { Primary endpoint: Change in ASM mass between BT treated } \\
\text { and control ( } 25 \text { weeks) }\end{array}$ & April 2018 \\
\hline
\end{tabular}




\begin{tabular}{|c|c|c|c|}
\hline $\begin{array}{l}\text { Study Name } \\
\text { NCT Identifier } \\
\text { Sponsor }\end{array}$ & Planned Enrollment & $\begin{array}{l}\text { Study Design and Objective } \\
\text { Primary Endpoints }\end{array}$ & $\begin{array}{l}\text { Estimated Final } \\
\text { Completion Date }\end{array}$ \\
\hline $\begin{array}{l}\text { Bronchial Thermoplasty: Mechanism } \\
\text { of Action and Defining Asthma } \\
\text { Phenotype } \\
\text { NCT02075151 } \\
\text { National University Hospital, } \\
\text { Singapore }\end{array}$ & $\begin{array}{l}\mathrm{n}=50 \text { patients with poorly controlled severe } \\
\text { asthma (ACT score }<20 \text { even with use of } \\
>500 \mathrm{mcg} \text { fluticasone/d or }>800 \mathrm{mcg} \\
\text { budesonide/d) }\end{array}$ & $\begin{array}{l}\text { Open-label, single-arm trial investigating the safety and efficacy } \\
\text { of BT } \\
\text { Primary endpoint: Change in ACT scores from baseline over a } \\
\text { 2-year period }\end{array}$ & May 2018 \\
\hline $\begin{array}{l}\text { Bronchial Thermoplasty in Severe } \\
\text { Asthma With Frequent Exacerbations } \\
\text { (THERMASCORT) } \\
\text { NCT02464995 } \\
\text { University Hospital, Strasbourg, } \\
\text { France }\end{array}$ & $\begin{array}{l}n=34 \text { with severe asthma and frequent } \\
\text { severe exacerbations ( } 4 \text { or more episodes } \\
\text { requiring systemic steroids for more than } \\
3 \text { days) in the past year }\end{array}$ & $\begin{array}{l}\text { Non-blinded RCT comparing patients who undergo BT + } \\
\text { medical management to those receiving medical management } \\
\text { alone } \\
\text { Primary endpoint: Change in severe exacerbations from } \\
\text { baseline over a 12-month period }\end{array}$ & November 2018 \\
\hline $\begin{array}{l}\text { Bronchial Thermoplasty Global } \\
\text { Registry } \\
\text { NCT02104856 } \\
\text { Boston Scientific Corporation }\end{array}$ & $\begin{array}{l}\mathrm{n}=160 \text { patients undergoing BT according to } \\
\text { labeled indications }\end{array}$ & $\begin{array}{l}\text { Observational patient registry following patient outcomes in } \\
\text { "real world" BT patients } \\
\text { Primary endpoint: Proportion of patients experiencing severe } \\
\text { exacerbations up to } 2 \text { years post-treatment }\end{array}$ & June 2019 \\
\hline $\begin{array}{l}\text { China Alair System Registry Study- } \\
\text { CARE Study } \\
\text { NCT02206269 } \\
\text { BSC International Medical Trading } \\
\text { (Shanghai) Co., Ltd. }\end{array}$ & $\begin{array}{l}\mathrm{n}=225 \text { patients with severe persistent } \\
\text { asthma undergoing BT according to labeled } \\
\text { indications }\end{array}$ & $\begin{array}{l}\text { Observational patient registry following patient outcomes in } \\
\text { "real world" BT patients } \\
\text { Primary endpoint: Rates of severe asthma exacerbations } \\
\text { following BT with the Alair System up to } 1 \text { year post-treatment }\end{array}$ & June 2019 \\
\hline $\begin{array}{l}\text { Bronchial Thermoplasty for Severe } \\
\text { Asthma With Dynamic Hyperinflation } \\
\text { (HEAT-SA) } \\
\text { NCT02618551 } \\
\text { University Hospital, Toulouse }\end{array}$ & $\begin{array}{l}\mathrm{n}=15 \text { patients with uncontrolled severe } \\
\text { asthma receiving optimal treatment and who } \\
\text { experienced at least } 2 \text { exacerbations } \\
\text { requiring systemic steroids in the past year }\end{array}$ & $\begin{array}{l}\text { Open-label, single-arm trial investigating the impact of BT on } \\
\text { dynamic hyperinflation phenomenon, which is a worsening of } \\
\text { bronchial obstruction following exercise } \\
\text { Primary endpoint: Change in dynamic hyperinflation from } \\
\text { baseline to } 3 \text { months post-BT }\end{array}$ & December 2018 \\
\hline $\begin{array}{l}\text { Hyperpolarized Magnetic Resonance } \\
\text { Imaging in Asthma Pre- and Post- } \\
\text { Bronchial Thermoplasty } \\
\text { NCT02263794 } \\
\text { Dr. Grace Parraga, University of } \\
\text { Western Ontario, Canada }\end{array}$ & $\mathrm{n}=14$ patients with severe asthma & $\begin{array}{l}\text { RCT comparing conventional BT to image-guided BT (Outcome } \\
\text { assessor-blinded study) } \\
\text { Primary endpoint: Whole lung and lobe specific VDP }\end{array}$ & December 2019 \\
\hline
\end{tabular}




\begin{tabular}{|c|c|c|c|}
\hline $\begin{array}{l}\text { Study Name } \\
\text { NCT Identifier } \\
\text { Sponsor }\end{array}$ & Planned Enrollment & $\begin{array}{l}\text { Study Design and Objective } \\
\text { Primary Endpoints }\end{array}$ & $\begin{array}{l}\text { Estimated Final } \\
\text { Completion Date }\end{array}$ \\
\hline $\begin{array}{l}\text { Bronchial Thermoplasty in Severe } \\
\text { Persistent Asthma } \\
\text { NCT01350336 } \\
\text { Boston Scientific Corporation }\end{array}$ & $\begin{array}{l}\mathrm{n}=284 \text { patients with severe persistent } \\
\text { asthma }\end{array}$ & $\begin{array}{l}\text { Open-label, single arm post-marketing study intended to } \\
\text { assess long-term safety and durability of BT efficacy in patients } \\
18 \text { years and older with severe persistent asthma } \\
\text { Primary endpoint: Proportion of patients experiencing severe } \\
\text { exacerbations up to } 5 \text { years post-treatment }\end{array}$ & January 2020 \\
\hline $\begin{array}{l}\text { A Prospective Observational Study of } \\
\text { Biopredictors of Bronchial } \\
\text { Thermoplasty Response in Patients } \\
\text { With Severe Refractory Asthma } \\
\text { (BTR Study) } \\
\text { NCT01185275 } \\
\text { Washington University School of } \\
\text { Medicine } \\
\text { Collaborators: } \\
\text { The Cleveland Clinic } \\
\text { National Jewish Health } \\
\text { University of Arizona } \\
\text { University of Chicago } \\
\text { Louisiana State University Health } \\
\text { Sciences Center in New Orleans } \\
\text { University of Alabama at Birmingham } \\
\text { Creighton University }\end{array}$ & $\mathrm{n}=190$ patients with severe asthma & $\begin{array}{l}\text { Prospective observational cohort study evaluating the role of } \\
\text { baseline clinical, physiologic, biologic and imaging markers in } \\
\text { clinical response to BT } \\
\text { Primary endpoint: Improvement in asthma quality of life } \\
12 \text { months post-treatment }\end{array}$ & August 2020 \\
\hline $\begin{array}{l}\text { Unraveling Targets of Therapy in } \\
\text { Bronchial Thermoplasty in Severe } \\
\text { Asthma (TASMA) Extension Study } \\
\text { NCT02975284 } \\
\text { Extension study of NCT02225392 } \\
\text { Academisch Medisch Centrum - } \\
\text { Universiteit van Amsterdam } \\
\text { (AMC-UvA) } \\
\text { Collaborator: } \\
\text { University Medical Center Groningen }\end{array}$ & $\mathrm{n}=40$ patients with severe asthma & $\begin{array}{l}\text { Prospective observational cohort study evaluating long-term } \\
\text { (5 years) clinical outcomes in patients enrolled in the } \\
\text { TASMA RCT } \\
\text { Primary endpoint: Rates of severe exacerbations, emergency } \\
\text { room visits and/or hospitalizations for respiratory symptoms up } \\
\text { to } 5 \text { years post-treatment }\end{array}$ & September 2024 \\
\hline
\end{tabular}

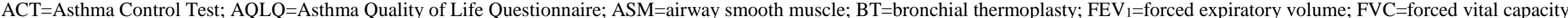
HXe MRI=hyperpolarized xenon-129 magnetic resonance imaging; RCT=randomized controlled trial; RISA=Research in Severe Asthma Trial; VDP=ventilation defect percent 


\section{Appendix F. Reference List for Appendixes B, C, and D}

1. Castro M, Rubin AS, Laviolette M, et al. Effectiveness and safety of bronchial thermoplasty in the treatment of severe asthma: a multicenter, randomized, double-blind, shamcontrolled clinical trial. Am J Respir Crit Care Med. 2010 Jan 15;181(2):116-24. Also available:

http://dx.doi.org/10.1164/rccm.2009030354OC. PMID: 19815809.

2. Pavord ID, Cox G, Thomson NC, et al. Safety and efficacy of bronchial thermoplasty in symptomatic, severe asthma. Am J Respir Crit Care Med. 2007 Dec 15;176(12):1185-91. Also available:

http://dx.doi.org/10.1164/rccm.200704-5710C. PMID: 17901415.

3. Cox G, Thomson NC, Rubin AS, et al. Asthma control during the year after bronchial thermoplasty. New Eng J Med. 2007 Mar 29;356(13):1327-7. Also available: http://dx.doi.org/10.1056/NEJMoa064707. PMID: 17392302.

4. Thomson NC, Rubin AS, Niven RM, et al. Long-term (5 year) safety of bronchial thermoplasty: asthma intervention research (AIR) trial. BMC Pulm Med. 2011 Feb 11;11:8. Also available: http://dx.doi.org/10.1186/14712466-11-8. PMID: 21314924.

5. Bicknell S, Chaudhuri R, Lee N, et al. Effectiveness of bronchial thermoplasty in severe asthma in 'real life' patients compared with those recruited to clinical trials in the same centre. Ther Adv Respir Dis. 2015

Dec;9(6):267-71. Epub 2015 Aug 24. Also available:

http://dx.doi.org/10.1177/1753465815601332. PMID: 26307767.

6. Pavord ID, Thomson NC, Niven RM, et al. Safety of bronchial thermoplasty in patients with severe refractory asthma. Ann Allergy Asthma Immunol. 2013 Nov;111(5):402-7. Also available:

http://dx.doi.org/10.1016/j.anai.2013.05.002. PMID: 24125149.

7. Wechsler ME, Laviolette M, Rubin AS, et al. Bronchial thermoplasty: long-term safety and effectiveness in patients with severe persistent asthma. J Allergy Clin Immunol. 2013 Dec;132(6):1295-302. Epub 2013 Aug 30. PMID: 23998657.
8. McCambridge J, Kruklitis R. Transient bronchial wall thickening after bronchial thermoplasty for asthma. J Bronchology Interv Pulmonol. 2016 Jan;23(1):51-3. Also available: http://dx.doi.org/10.1097/LBR.0000000000000 240. PMID: 26705012.

9. Nguyen DV, Murin S. Bronchial artery pseudoaneurysm with major hemorrhage after bronchial thermoplasty. Chest. 2016 Apr;149(4):e95-7. Also available: http://dx.doi.org/10.1016/j.chest.2015.09.016. PMID: 27055718.

10. Balu A, Ryan D, Niven R. Lung abscess as a complication of bronchial thermoplasty. J Asthma. 2015 Aug 9;52(7):740-2. Also available: http://dx.doi.org/10.3109/02770903.2015.1005 844. PMID: 25766745.

11. Facciolongo N, Menzella F, Lusuardi M, et al. Recurrent lung atelectasis from fibrin plugs as a very early complication of bronchial thermoplasty: a case report. Multidiscip Respir Med. 2015;10(1):9. Also available: http://dx.doi.org/10.1186/s40248-015-0002-7. PMID: 25852934.

12. Doeing DC, Husain AN, Naureckas ET, et al. Bronchial thermoplasty failure in severe persistent asthma: a case report. J Asthma. 2013 Sep;50(7):799-801. Also available: http://dx.doi.org/10.3109/02770903.2013.7969 74. PMID: 23651158.

13. Doeing DC, Mahajan AK, White SR, et al. Safety and feasibility of bronchial thermoplasty in asthma patients with very severe fixed airflow obstruction: a case series. J Asthma. 2013 Mar;50(2):215-8. Also available: http://dx.doi.org/10.3109/02770903.2012.7519 97. PMID: 23252954.

14. Mahajan AK, Hogarth DK. Bronchial thermoplasty: therapeutic success in severe asthma associated with persistent airflow obstruction. J Asthma. 2012 Jun;49(5):527-9. Also available: http://dx.doi.org/10.3109/02770903.2012.6761 24. PMID: 22515527.

15. Cox G, Miller JD, McWilliams A, et al. Bronchial thermoplasty for asthma. Am J Respir Crit Care Med. 2006 May;173(9):965-9. Also available: http://dx.doi.org/10.1164/rccm.2005071162OC. PMID: 16456145. 
16. Schatz M, Kosinski M, Yarlas AS, et al. The minimally important difference of the Asthma Control Test. J Allergy Clin Immunol. 2009 Oct;124(4):719-23.e1. Also available: http://dx.doi.org/10.1016/j.jaci.2009.06.053. PMID: 19767070.

17. Juniper EF, Svensson K, Mörk AC, et al. Measurement properties and interpretation of three shortened versions of the asthma control questionnaire. Respir Med. 2005 May;99(5):553-8. Also available: http://dx.doi.org/10.1016/j.rmed.2004.10.008. PMID: 15823451.

18. Juniper EF, Gruffydd-Jones K, Ward S, et al. Asthma Control Questionnaire in children: validation, measurement properties, interpretation. Eur Respir J. 2010 Dec;36(6):1410-6. Also available: http://dx.doi.org/10.1183/09031936.00117509. PMID: 20530041.

19. Juniper EF, Buist AS, Cox FM, et al. Validation of a standardized version of the Asthma Quality of Life Questionnaire. Chest. 1999 May;115(5):1265-70. PMID: 10334138.

20. Juniper EF, Guyatt GH, Cox FM, et al. Development and validation of the Mini Asthma Quality of Life Questionnaire. Eur Respir J. 1999 Jul;14(1):32-8. PMID: 10489826.
21. Juniper EF, Guyatt GH, Willan A, et al. Determining a minimal important change in a disease-specific Quality of Life Questionnaire. J Clin Epidemiol. 1994 Jan;47(1):81-7. PMID: 8283197.

22. Juniper EF, Svensson K, Mörk AC, et al. Modification of the asthma quality of life questionnaire (standardised) for patients 12 years and older. Health Qual Life Outcomes. 2005 Sep 16;3:58. Also available: http://dx.doi.org/10.1186/1477-7525-3-58. PMID: 16168050.

23. Wyrwich KW, Ireland AM, Navaratnam P, et al. Validation of the AQLQ12+ among adolescents and adults with persistent asthma. Qual Life Res. 2011 Aug;20(6):903-12. Also available: http://dx.doi.org/10.1007/s11136010-9821-3. PMID: 21184185.

24. Juniper EF, Guyatt GH, Feeny DH, et al. Measuring quality of life in children with asthma. Qual Life Res. 1996 Feb;5(1):35-46. PMID: 8901365.

25. Juniper EF, Guyatt GH, Feeny DH, et al. Measuring quality of life in the parents of children with asthma. Qual Life Res. 1996 Feb;5(1):27-34. PMID: 8901364.

26. Santanello NC, Zhang J, Seidenberg B, et al. What are minimal important changes for asthma measures in a clinical trial? Eur Respir J. 1999 Jul;14(1):23-7. PMID: 10489824. 